\title{
ARTICLES
}

\section{GOD, CIVIC VIRTUE, AND THE AMERICAN WAY: RECONSTRUCTING ENGEL}

\section{Corinna Barrett Lain*}

If ever a decision embodied the heroic, countermajoritarian function we romantically ascribe to judicial review, it was the 1962 decision that struck down school proyer-Engel ४. Vitale. Engel provoked more outrage, more congressional attempts to overturn it, and more attacks on the Justices than perhaps any other decision in Supreme Court history. Indeed, Engel's countermajoritarian narrative is so strong that scholars have largely assumed that the historical record supports our romanticized conception of the case. It does not. Using primary source materials, this Article reconstructs the story of Engel, then explores the implications of this reconstructed narrative. Engel is not the countermajoritarian case it seems, but recognizing that allows us to see Engel for what it is: a remarkably rich account of Supreme Court decisionmaking that furthers a number of conversations in constitutional law. Engel adds a new strand to a burgeoning body of scholarship on the power of culture in general and social movements in particular, to generate constitutional change. It presents a rare glimpse of the Justices explicilly engaging in a dialogue with the American public. And it exposes qualitative differences in the forms that popular constitutionalism might take, with implications for the theory itself. In the end, Engel still offers valuable insights about Supreme Court decisionmaking and the role of judicial review. They just aren't the insights we tend to think.

* Professor of Law and Associate Dean of Faculty Development, University of Richmond School of Law. This Article benefited from faculty workshops at Washington and Lee University, University of Richmond, and Florida International University. Thanks to Tom Berg, Eric Berger, Christopher Corts, Jessica Erickson, Jim Gibson, Mark Graber, Meredith Harbach, Mary Heen, Bob Highfill, Paul Horwitz, Sandy Levinson, Shari Motro, Wendy Perdue, Larry Solum, Andy Spalding, Rachel Suddarth, Winnifred Sullivan, Eugene Volokh, and the Stanford Law Review editors, particularly Jake McMahon, for feedback on early drafts. Thanks also to Jessica Barile, Christine Crawford, Catherine Gray, Katy Grover, and Julic Kennedy for excellent research assistance, to Gail Zwimer of the Richmond Law Library for her expertise in finding sources, and to Kristen Osenga for encouraging me to pursue this project. Special thanks to Hugo Black, Jr., for granting access to Justice Black's papers. 


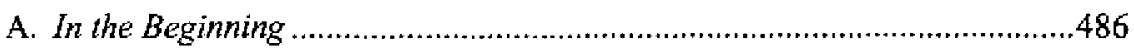

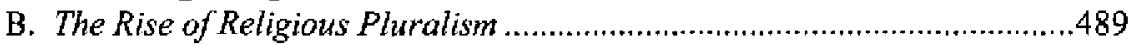

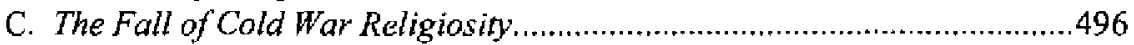

D. For the Justices, a Relatively Easy Case ..............................................499

II. WHAT HAPPENED NEXT .........................................................................507

A. "When We Won the Case, All Hell Broke Loose" ....................................507

B. The Role of Media and Misunderstanding ...........................................514

C. The Role of Religious (and Other) Elites...............................................525

D. The Supreme Court Responds: School District of Abington Township v. Schempp.

III. WHY IT MATTERS ...................................................................................539

A. The Reality of Engel 's Heroic, Countermajoritarian Narrative................539

B. The Influence of Culture in Generating Constitutional Change.................546

C. A Rare "Strong Form" of the Dialogic Function of Judicial Review ........549

D. Not All Popular Constitutionalism Is Created Equal ..............................55 I

CONCLUSION.

\section{INTRODUCTION}

Constitutional lore casts the Supreme Court as a countermajoritarian protector, champion of unpopular minorities against tyrannical majority rule. ${ }^{1}$ Over the last several decades, this romanticized conception of the Court has softened somewhat as empirical work on Supreme Court decisionmaking has mounted. ${ }^{2}$ Today, "underground conventional wisdom" ${ }^{33}$ within the legal academy is what political scientists have known, and shown, for almost fifty years: the Supreme Court is arfundamentally majoritarian institution. ${ }^{4}$

1. The Supreme Court itself has promoted this narrative, most famously in a 1938 footnote, but elsewhere as well. See United States v. Carolene Prods. Co., 304 U.S. 144, 153 $\mathrm{n}, 4$ (1938) ("[P]rejudice against discrete and insular minorities may be a special condition... which may call for a correspondingly more searching judicial inquiry."); see also Chambers v. Florida, 309 U.S. 227, 24] (1940) (" $[\mathrm{C}]$ ourts stand . . . as havens of refuge for those who might otherwise suffer because they are helpless, weak, outnumbered, or because they are non-conforming victims of prejudice and public excitement."). For a famous theory of judicial review based on this account, see JoHN HART ELY, DEMOCRACY AND DISTRUST: A THEORY OF JUDICIAL REVIEW (1980).

2. Lee Epstein \& Andrew D. Martin, Does Public Opinion Influence the Supreme Court? Possibly Yes (but We're Not Sure Why), 13 U. PA. J. Const. L. 263, 265 tbl.1 (2010) (summarizing the results of nine quantitative studies from 1993 to 2009 showing the Supreme Court's responsiveness to public opinion).

3. Jeffrey Rosen, The Most Democratic Branch: How the Colrts Serve AMERICA, at xii (2006).

4. For classic empirical studies establishing the Supreme Court's majoritarian decisionmaking proctivities, see, for example, Robert A. Dahl, Decision-Making in a Democracy: The Supreme Court as a National Policy-Maker, 6 J. PUB. L. 279 (1957); and David G. Barnum, The Stupreme Court and Public Opinion: Judicial Decision Making in the Post-New Deal Period, 47 J. POL, 652 (1985). For more recent empirical work, see Epstein \& Martin, supra note 2. 
For those who study Supreme Court decisionmaking and the role of judicial review, the question then becomes how to understand the Court when it deviates from the general rule. If the Supreme Court is mainly majoritarian, what can we learn from when it is not? The answer, as Barry Friedman has recognized, is "remarkably impoverished.",

Against this backdrop, Engel v. Vitale ${ }^{6}$-the 1962 decision that struck down school prayer-stands as a conspicuous case for renewed scholarly attention. Engel started with a want ad. ${ }^{7}$ A parent was looking for others to join him in challenging a New York school board's decision to begin the school day with a short ecumenical prayer: "Almighty God, we acknowledge our dependence upon Thee, and we beg Thy blessings upon us, our parents, our teachers and our Country." ${ }^{8}$ Steven Engel answered the ad, as did the parents of a number of other children of varying religious backgrounds. ${ }^{9}$ They lost in the trial court. ${ }^{10}$ They appealed, and lost again. ${ }^{11}$ And in New York's highest appellate court, they lost yet again. ${ }^{12}$ Then the Supreme Court granted certiorari and invalidated the prayer under the First Amendment's Establishment Clause. ${ }^{13}$ The nation freaked.

Within the academy, Engel is widely regarded as one of the most unpopular decisions in Supreme Court history, ${ }^{14}$ and for seemingly good reason. Engel

5. Barry friedman, The WiLl of the People: how Public opinion has Influenced the Supreme Court and Shaped the Meaning of the Constitution 373 (2009).

6. 370 U.S. 421 (1962).

7. See CBS Reports: Storm over the Supreme Court Part II; The School Prayer Case (CBS television broadcast Mar. 13, 1963) [hereinafter CBS Reports: The School Prayer Case].

8. Engel, 370 U.S. at 422 (internal quotation marks omitted). Students who wished to leave the roon were allowed to do so, although the prayer was so short that they generally did not bother. See infra note 135 and accompanying text.

9. Around fifty people initially answered the ad, but many dropped out, leaving ten children and their parents as the original plaintiffs in the case. Engel was Jewish, but the plaintiffs also included a Unitarian, a member of the Society for Ethical Culture, and a nonbeliever. See Engel, 370 U.S. at 423; CBS Reports: The School Prayer Case, supra note 7.

10. See Engel v. Vitale, 191 N.Y.S.2d 453, 496 (Sup. Ct. 1959).

11. See Engel v. Vitale, 206 N.Y.S.2d 183, $183-84$ (App. Div. 1960) (per curiam).

12. See Engel v. Vitale, 176 N.E.2d 579, 582 (N.Y. 1961).

13. See Engel, 370 U.S. at 424. For a theory of why the Supteme Court granted certiorari in the case, see note 383 and accompanying text below.

14. See Bruch J. Dierenfield, The Battle over School. Prayer: How Engel $v$. VITALE Changed AMERICA 145 (2007) ("Constitutional experts maintain that Engel was "a wildly unpopular decision,' engendering more public hostility than almost any previous opinion in the Court's history ...."); LuCAS A. POWE, Jr., The WARrEn CourT AND AMERICAN POLITICS 187 (2d prtg. 2001) ("[A] later study found more widespread opposition to Engel than to any other case."); RODNEY K. SMITH, PUBLIC PRAYER AND THE CONSTITLTION: A CASE STUDY IN CONSTITUTIONAL INTERPRETATION 175 (1987) ("Public furor which was without equal in any prior case before the Supreme Court arose after the Engel decision was announced.") 
provoked more outrage than Dred Scott $v$. Sandford. ${ }^{15}$ It infuriated more areas of the country than Brown v. Board of Education. ${ }^{16}$ It inspired more congressional attempts to nullify it and impassioned vows to evade it than Roe $v$. Wade. ${ }^{17}$ And it was intensely unpopular with the American public. The Supreme Court received more mail on Engel than it had ever received on a single case-around 5000 letters, "mostly negative," in the first month after the decision $^{18}$-and a Gallup poll taken shortly after the decision registered disapproval of the ruling at seventy-nine percent. ${ }^{19}$ The Justices had misbehaved before, but "never in the wildest of their excesses" had they gone as far as they did in Engel. ${ }^{20}$ To the people and their representatives, Engel was more than a misreading of the Establishment Clause. It was an affront to God, civic virtue, and the American way.

Indeed, Engel's countermajoritarian narrative is so strong that the tension between minority rights and majority rule was explicit in the framing of the

15. 60 U.S. (19 How.) 393 (1857); see DIERENFIELD, supra note 14, at vii (noting that Engel was "greeted with more shock and criticism than Dred Scott v. Sandford"). Given the vastly different historical time frames, the comparison is a difficult one; but Dred Scott is (like the other cases mentioned here) a standard-bearer of countermajoritarianism, so I think the comparison worthy-and valid. See infra Part II.A (discussing the reaction to Engel, which included public denunciations, picketing, billboards, letter-writing campaigns, editorials, resolutions, pay retaliation, legislation, vows of defiance, noncompliance, and calls to amend the Constitution, impeach the Justices, strip their jurisdiction, buy them Bibles, and inscribe the words "In God We Trust" above their bench).

16. 347 U.S. 483 (1954); see THE SUPREME COURT IN CONFERENCE (1940-1985): THE PrTyate Discussions Behind Nearly 300 Supreme Court Decisions 425 (Del Dickson ed., 2001) [hereinafter SUPREME COURT IN CONFERENCE] (comparing Engel to Brown, and noting that "this time the hostility was not confined to one region of the country--although southerners were more angry than most" (italics omitted)); The Court Decision-and the School Prayer Furor, NEwSWEEK, July 9, 1962, at 43, 44 (reporting on the "swell of indignation, astonishment, and bewilderment that swept across the nation" in the wake of Engel).

17. 410 U.S. 113 (1973); see Robert S. Alley, School Prayer: The Court, tHe CONGRESS, AND THE FIRST AMENDMENT 107 (1994) ("Of all the Court rulings of this century none has sparked more action in Congress than Engel."); DiERENFIELD, supra note 14, at 150 ("Nearly one thousand constitutional amendments have been proposed to overtum the regents' prayer ruling."); Nation Chooses Sides in Fight over Prayer, U.S. NEwS \& WoruD REP., May 18, 1964, at 63, 63 ("Fifteen States have refused to discontinue prayer and Bible reading in their schools.").

18. Bruce J. Dierenfield, Engel v. Vitale, in The Public Debate over Controversial SuPREME CourT DeCisIons 215, 220 (Melvin I. Urofsky ed., 2006); see also Mail Pours into Court on its Prayer Decision, N.Y. TIMES, June 29, 1962, at 11 (noting that mail on Engel "was reported to be the largest in the tribunal's history").

19. See 3 George H. Gallup, The Gallup Poll: Public Opinion 1935-1971, at 1779 (1972) (reporting results of a July 26-31, 1962, survey asking, "Do you approve or disapprove of religious observances in public schools?"). For subscquent polling data, see note 271 below.

20. See Opinion of the Week: Prayers in School, N.Y. TIMES, July 1, 1962, $\$ 4$, at 9 (quoting Senator Herman Talmadge of Georgia). 
case. It was in the parties' arguments. ${ }^{21}$ It was in the public discourse. ${ }^{22}$ And it was in Justice Black's delivery of the decision itself. ${ }^{23}$

Little wonder, then, that as scholars today debate the nature of Supreme Court decisionmaking, Engel is-as it has been for fifty years-a go-to case. For some, it is proof of the Supreme Court's staunchly countermajoritarian capacity. ${ }^{24}$ For others, it is the rare exception to a reliably majoritarian Supreme Court. ${ }^{25}$ Either way, Engel stands as a sterling example of countermajoritarian decisionmaking, a classic case of judicial bravery in the face of public sentiment the opposite way.

21. See, e.g., Brief of Intervenors-Respondents at 45, Engel v. Vitale, 370 U.S. 421 (1962) (No. 468), 1962 WL 115863 ("Petitioners seek, under the cloak of the First Amendment, to coerce the vast majority into subservience to their demands." (bolding omitted)); Oral Argument at 43:55, Engel, 370 U.S. 421 (No. 468), available at http://www.oyez.org /cases/1960-1969/1961/1961_468 ("[Respondents] boldly argue that the majority should control in this particular instance, and [that] this is a case where the minority is imposing its views upon the majority. Of course, our answer to that is simple. We say that the Constitution-the very purpose of the Constitution is to protect the minority against the majority.").

22. See Editorial, Prayer Is Personal, N.Y. Trmes, June 27, 1962, at 34 ("Doubtless those who oppose school prayers are a minority. But the Constitution was designed precisely to protect minorities...."); infra notes 188-91 and accompanying text (discussing criticism of Engel for subjecting majority will to minority rule).

23. See Anthony Lewis, Supreme Court Outlaws Official School Prayers in Regents Case Decision: Ruling Is 6 to I, N.Y. TIMEs, June 26, 1962, at 1 (reporting Justice Black's "extemporaneous comments" from the bench while announcing Engel, including the comment that "[i] $\mathrm{f}$ there is any one thing clear in the First Amendment, it is that the right of the people to pray in their own way is not to be controlled by the election returns" (internal quotation marks omitted)).

24. See, e.g., Tara Leigh Grove, A (Modest) Separation of Powers Success Story, 87 NOTRE DAME L. REV, 1647, 1670-71 (2012) ('For example, the Warren Court's decisions on issues like school prayer... were extremely unpopular.... Thus, it appears that federal courts do have some leeway to . . protect "unpopular' constitutional values."); Daryl J. Levinson, Parchment and Politics: The Positive Puzzle of Constitutional Commitment, 124 HARV. L. REV. 657, 736 (2011) ("Rcal questions about the viability of judicial power arise only when courts act counter to the interests of the national political branches or popular majorities. These cases do exist: Supreme Court decisions invalidating school prayer . . have been unpopular with majorities of the public."); Richard H. Pildes, Is the Supreme Court a "Majoriturian" Institution?, 2010 SuP. CT. REv. 103, 125 \& n.77 (citing "the Court's highly unpopular school-prayer decisions of the $1960 \mathrm{~s}$ " as a counterexarmple to claims that the Supreme Court is constrained by political and/or popular majorities).

25. See, eg, FRIEDMAN, supra note 5, at 263-66 (discussing Engel within the larger historical context of alignment of the Justices with popular opinion); Lori A. Ringhand, In Defense of Ideology: A Principled Approach to the Supreme Court Conformation Process, 18 WM. \& MARY BILL RTS. J. 131, 135 n.19 (2009) ("While some Supreme Court decisions almost certainly are genuinely countermajoritarian (the flag burning decisions and much of the Court's current school prayer jurisprudence probably fall into this group), such cases appear to be rare."); Michacl J. Klaman, Rethinking the History of American Freedom, 42 WM. \& MARY L. REV. 265, 281 (2000) (book review) ("[N]one of this is to deny that occasionally the Supreme Court does strike blows in defense of freedoms that do not enjoy majoritarian support. Clearly, the Court's decisions invalidating schoot prayer . . have not commanded majority support."). 
Perhaps because Engel's countermajoritarian narrative is so strong, few scholars have paused to consider whether the case in fact tells the story of Supreme Court decisionmaking for which it is famous. Thus far, only one law review article has dedicated its pages to the larger sociopolitical context in which Engel was decided, and even there Engel is but a piece of a larger Establishment Clause history. ${ }^{26}$ Still lacking is a robust account of the decisionmaking in Engel: how larger sociopolitical forces influenced the case and its timing, what the Justices thought when they decided it, why the nation reacted as it did, and ultimately, what the case says about the Supreme Court's countermajoritarian capacity. My aim is to provide such an account.

Using primary source materjals, this Article reconstructs the story of Engel, providing a dramatically different account of the case than that which appears in the conventional script. The contribution is twofold. First, this Article challenges the prevailing view of Engel as proof of the Supreme Court's countermajoritarian capacity. On the surface, Engel exudes judicial bravery, but closer examination shows that to be a façade. To the extent the Justices in Engel played a countermajoritarian role at all, they did so unwittingly. Indeed, all indications are that if the Justices had known just how unpopular Engel would be, they would not have taken the case in the first place.

Second, this Article brings to light what the surface appeal of Engel's countermajoritarian narrative has eclipsed-a remarkably rich account of Supreme Court decisionmaking that furthers a number of conversations in constitutional law. Engel is a testament to the power of the 1950 s ecumenical movement in generating constitutional change, adding a new thread to a burgeoning body of scholarship in the "court and culture" literature. It shows the Justices explicitly engaging in a dialogue with the American public, revealing a rare "strong form" of the dialogic function of judicial review. It illustrates the variety of forms that popular constitutionalism might take, offering an opportunity to think about qualitative differences in the way democratic dissent fosters constitutional discourse. And along the way it illuminates issues that are not at the forefront of conversations in constitutional law, but perhaps should be: how the media filters our perception of judicial review, what the support of highly educated cultural elites might say about an issue, and the ways in which messaging

26. See John C. Jeffries, Jr. \& James E. Ryan, A Political History of the Establishment Clause, $100 \mathrm{MrCH}$. L. REv. 279, 280-81, 318-27 (2001). Three others offer substantial contributions that merit mention here. See Thomas C. Berg, The Story of the School Prayer Decisions: Civil Religion Under Assault, in FIRST AMENDMENT STORIES 193, 196 (Richard W. Garnett \& Andrew Koppelman eds., 2012) (telling a similar, albeit limited, story of Engel); Michael J. Klarman, Rethinking the Civil Rights and Civil Liberties Revolutions, 82 VA. L. REv. 1, 46-62 (1996) (outlining the contours of a historical understanding of the Establishment Clause and stating the need for legal scholarship in this area); Steven D. Smith, Constitutional Divide: The Transformative Significance of the School Prayer Decisions, 38 PEPP. L. REV. 945, 1015-16 (2011) (discussing Engel's cultural backdrop as part of a larger discussion about its transformative significance in establishing a secularist constitutional conception of America). 
can matter. Engel offers a wealth of insights into Supreme Court decisionmaking and the role of judicial review, but only once we have a robust understanding of what happened in the case.

Before proceeding, a point of clarification metits mention. This Article is not concerned with whether Engel was correctly decided; it is concerned with why the Justices decided it. Nor is this Article concerned with doctrinal developments since Engel, at least after $1963{ }^{27}$ I take Engel for the case it was, and its broader implications for what contemporary observers understood them to be. All that is to reiterate that this Article is about understanding the Justices' decisionmaking in Engel, and explaining why, if the understanding I offer is right, it was obscured by what happened in the aftermath of the case. Only by understanding the decisionmaking in Engel can we begin to understand what its contributions to constitutional theory are, and aren't.

The discussion proceeds as follows. Part I shows how history shaped $E n$ gel, tracing the major historical developments in the school prayer controversy, situating the case against its larger sociopolitical backdrop, and examining the Justices' decisionmaking in the case. Part II tums to the aftermath of Engel, detailing the events that occurred in Engel's wake, explaining why the nation reacted as it did, and presenting the Supreme Court's 1963 Bible reading decision in School District of Abington Township v. Schempp ${ }^{28}$ as an important part of Engel's narrative. Part III discusses the implications of this reconstructed account, rejecting the heroic, countermajoritarian narrative for which Engel is famous and exploring the vastly underappreciated contributions it makes to a number of other conversations in constitutional law. In the end, Engel is as important and instructive as it always was-just not for the reasons conventional wisdom would have us think.

\section{HOW HISTORY SHAPED ENGEL}

To understand Engel, one must first understand what happened before it. This Part aims to provide that understanding, showing how history shaped $E n$ gel in various ways. ${ }^{29}$ First, I explain how the controversy over school prayer began. Then I show how the rise of religious pluralism made school prayer an intractable problem by the mid-twentieth century, and how Cold War religiosity kept the ruling at bay until 1962 . I conclude with an inside look at the Justices* decisionmaking in Engel, which seemed to them a relatively easy, uncontroversial case.

27. I do consider the Supreme Court's ruling in School District of Abington Township v. Schempp, 374 U.S. 203 (1963), but only because it sheds light on the heroic, countermajoritarian narrative canonized in Engel. See infra Part II.D.

28. 374 U.S. at 205, 207 (invalidating Bible reading and recitation of the Lord's Prayer in public schools).

29. The account is necessarily simplistic. Religious and other changes over several hundred years defy distillation without some glossing over of the nuances, crosscurrents, and complications along the way. 


\section{A. In the Beginning}

In the beginning, school prayer was not controversial. The colonists may have come to the New World to escape an established religion, but that did not mean they were against religious establishment per se. To the contrary, most of America's earliest settlers were staunch supporters of state-sponsored religion; they just wanted it to be theirs. ${ }^{30}$ Schools played an integral part in this endeavor, as they were the place where children leamed to read religious doctrine. ${ }^{31}$ Thus, from the start, children in the colonies practiced religious observances in school. Indeed, that was the very point.

America's independence and adoption of the First Amendment had no effect on this arrangement, ${ }^{32}$ but immigration in the 1830 s and 1840 s did. Catholics and new strands of Protestants streamed into America, placing strain on the communities already in place. ${ }^{33}$ Schools seemed an ideal place to "American-

30. Nine of the thirteen original colonies had an established church. See LEONARD W. Levy, The Establishment Clause: Religion and the First Amendment 1, 5 (1994) (discussing establishments of religion in the colonies); Michael W. McConnell, Establishment at the Founding, in No EstablisHMENT OF Religion: AMERICA's ORIGINAL CONTRIBUTION TO RELigious LiBER TY 45, 45-47 (T. Jeremy Gunn \& John Witte, Jr. eds., 2012) [hercinafter No ESTABLISHMENT OF RELIGION] (same).

31. See Donald E. Boles, The Bible, Religion, And the Puble Schools 6 (3d ed. 1965) (" $[T]$ he motivating force behind public education in the American Colonies was to enable the students to read the Bible and to become better versed in Protestant religious dogma."); Steven K. Green, The Bible, the School, and the Constrtution: The Clash That Shaped MOdern ChurCh-STAte Doctrine 13 (2012) (noting that America's earliest schools were "predominately religious (i.e., Protestant), with a heavy emphasis on reading religious texts and memorizing religious doctrine"); STEPHEN D. SOLOMON, ELLERY'S Protest: How ONe Young Man Defied TRadition \& Sparked the Battle over SCHOOL PRAYER 99-101 (2007) ("Most of the colonial and early nineteenth-century schools recognized religion as a primary goal of learning. At the very least, children had to become literate in order to read the Bible and learn their prayers."). As Michael McConnell notes, by the 1780 s, religious establishment was less about theology and more about the role of religion in preserving morals for the good of society. McConnell, supra note 30, at 59-62. This civic justification-the inculcation of morals-became the central justification for religious teaching in schools as wetl. For a discussion of the prayer in Engel as an example of that phenomenon, see note 95 and accompanying text below (noting the prayer's stated purpose as aiding the spiritual and moral development of children in public schools).

32. The First Amendment reads, "Congress shall make no law respecting an establishment of religion"; it says nothing about the states. See U.S. ConsT, amend. I. Indeed, debates in the First Congress make clear that the First Amendment's Establishment Clause was intended only as a limit on the federal government, leaving the states to do as they pleased. See Kurt T. Lash, The Second Adoption of the Estublishment Clause: The Rise of the Nonestablishment Principle, 27 ARIz. ST. L.J. 1085, 1088-89 (1995) ("[T]he original Establishment Clause was intended to prohibit federal power over the subject of religion, reserving the same to the states. In this way, the original Establishment Clause expressed the principle of federalism: The federal government could neither establish religion at the federal level, nor disestablish religion in the states."); $i d$. at 1090-92 (citing debates in the state ratifying conventions and the First Congress to prove the point).

33. See BOLES, supra note 31 , at 23 (discussing immigration in the 1830 s and 1840 s). 
ize" these immigrants, ${ }^{34}$ but there was a hitch: the religious instruction was sect-specific, alienating the newcomers. ${ }^{35}$ The renowned Horace Mann, America's first state secretary of education and founder of our public school system, ${ }^{36}$ had a solution. Keep religion in and differences out, he reasoned, by teaching basic Christianity--only those features that all denominations had in common. ${ }^{37}$

Thus began the so-called "nonsectarian" approach to religion in public schools. ${ }^{38}$ Allow the Bible "to speak for itself," Mann famously quipped. ${ }^{39}$ Schools could accommodate different denominations by reducing religious instruction to two components: Bible reading without commentary and school prayer. ${ }^{40}$

For Protestants, Bible reading and school prayer-typically the Lord's Prayer, itself a form of Bible reading-worked well enough. ${ }^{41}$ But such prac-

34. See Samuel Windsor Brown, The Secllarization of American Education: As Shown by State Legislation, STate Constitutional Provisions and State Supreme COURT DECISIONS 2 (Russell \& Russell 1967) (1912) (discussing the importance of education as a means of "Americanizing the diverse racial and cultural elements composing our population"). For a slightly darker articulation of the point, see Thomas C. Berg, Disestablishment from Blaine to Everson: Federalism, School Wars, and the Emerging Modern State, in No Est FBLISHMENT OF RELIGION, supra note 30, at 307, 315 ("The proponents of common schools generally viewed Catholicism as a threat, seeing it as full of theological superstitions and, because of its hierarchical structure and theology, as antidemocratic. The common, or public, schools sought to 'Americanize' the immigrants and, by educating children of Protestant denominations together, strengthen values of demoeracy and individual freedom to which Protestantistn was thought to be crucial.").

35. See Boles, supra note 31, at 23-25; Brown, supra note 34, at 2.

36. See JoAN DelFatTore, The Fourth R: Conflicts over Religion IN America's PUBLIC SCHOOLS 14 (2004); see also BOLES, supra note 31, at 23 (describing Horace Mann as "the father of the public school system in America").

37. See BoLEs, supra note 31, at 24-27; Jeffries \& Ryan, supra note 26, at 297-98.

38. See DELFATTORE, supra note 36 , at 14 ("tT] he approach that soon became dominant in many states was the establishment of schools deemed 'nonsectarian' at the time, although by today's standards they would be better described as pan-Protestant."); JolfN Herbert Laubach, School Prayers: Congress, the Courts, aNd the Public 78 (1969) ("The concept of nonsectarianism was regarded as synonymous with "common core reljgion, 'common denominator religion,' 'civil or civic religion,' and 'public school religion." "). For a history of the common (i.e., public) school movenent, see generally CARL F. Kaestle, Pillars of the Republic: Common Schools and American Society, 1780-1860 (1983).

39. See Horace ManN, Report for 1848, in 3 LIFE AND Works of Horace ManN: ANNUAL ReporTS ON EDUCATION 640, 729-30 (Mary Mann ed., Boston, Horace B. Fuller 1868) (emphasis omitted).

40. See Solomon, supra note 31, at 5, 131 .

41. See id. (discussing recitation of the Lord's Prayer and Bible reading as the core of nonsectarian religious practices in school); $i d$. at 160 ("Reading the Bible without comment had been a brilliant innovation in the 1840 s by Horace Mann, ... who pleased various Protestant factions by including the Bible in the curriculum while avoiding the commentary that had caused bitter divisions in the past."). But see Douglas Laycock, "Noncoercive" Support for Religion: Another False Claim About the Establishment Clause, 26 VAL. U. L. 
tices were not "nonsectarian" for everyone. Catholics used the Douay version of the Bible; schools (and Protestants) used the King James. ${ }^{42}$ Catholics thought Bible reading required the guiding hand of clergy; schools (and Protestants) thought the Bible could speak for itself. ${ }^{43}$

Catholics complained bitterly that so-called "nonsectarian" religious observances weren't. Protestants had their schools, they argued, so Catholics should have theirs-complete with government funding. ${ }^{44}$ The argument fell flat. But the claim itself fed nativist fears and reprisals, adding to the tension already mounting as Catholics resisted religious observances in school as best they could. ${ }^{45}$ Children were severely beaten, priests tarred and feathered. ${ }^{46} \mathrm{Ri}$ oting in Cincinnati and Philadelphia left homes burned and dozens dead. ${ }^{47}$

In the end, the notorious "Bible Wars" 48 only hardened nativist sentiment, inciting a drive for a constitutional amendment to " $[\mathrm{k}]$ eep the church and state forever separated" by prohibiting the use of public money for sectarian schools. ${ }^{49}$ The Blaine Amendment failed (barely), ${ }^{50}$ but states passed "Baby

REv. 37, 51 (1991) (noting that the nonsectarian approach "was not entirely satisfactory even among Protestants").

42. See Laycock, supra note 41 , at 51 ("Catholics used the Douay translation of the Bibie, and objected to reading the King James translation, which they called 'the Protestant Bible." "); infra note 43.

43. See DELFATTORE, supra note 36, at 20-21 ("The [Catholic] Church defines itself as the only true interpreter of the Bible, and the Catholic translation, known as the Douay Version, includes footnotes and commentary giving the Church's explanation of certain texts... [T] he bishops saw [Bible reading without commentary] as hostile to the Church's assertion that even adults, let alone children, are incompetent to interpret the Bible for themselves.").

44. See Brown, supra note 34, at 157 (describing the view of "[t]hose who advocate religious, sectarian schools" that "in educating the youth in such schools they are rendering to the state a distinct service, and are relicving the state of an obligation and a burden, and for this reason are entitled to state assistance").

45. See DIERFNFIELD, supra note 14, at 19-20 ("It was the Catholic drive for government funding of these schools that inflamed public opinion more than any other religious issue in the nineteenth century.").

46. See DiLFATTORE, supra note 36, at $43-49$ (discussing incidents).

47. For an in-depth discussion, see Michael Feldherg, The PHILAdelphia Riots of 1844: A Study of ETHNiC Conflict (1975); and GreEn, supra note 31, at 93-129 (discussing the Cincinnati "Bible War" of 1869-1873).

48. See Susan Dudley Gold, Engel v. Vitale: Prayer in the Schools 49 (2006) (discussing the term's origin in newspapers reporting on the Cincinnati riots).

49. BOLES, stupra note 31, at 30-32 (discussing the Blaine Amendment of 1876 and quoting President Grant's 1875 speech proposing it). For an argument that the Blaine Amendment, which also sought to apply the First Amendment to the states, was more a nativist political ploy than a proposed change to contemporary understandings of church-state relations, see Steven K. Green, The "Second Disestablishment": The Evolution of Nineteenth-Century Understandings of Separation of Church and State, in No ESTABLISHMENT OF RELIGION, supra note 30 , at $280,298-99$ (noting that the states had already formally disestablished religion by 1876 , so incorporation would have changed nothing, and seventeen states had already taken a no-funding stance toward parochial schools). 
Blaine" amendments in its wake, ${ }^{51}$ and Congress required newly admitted states to do the same. ${ }^{52}$ When Catholics pointed out that public money was already going to sectarian schools, they were met with a single response: they were wrong. ${ }^{53}$

By 1890 , the principle of separation of church and state had become popularized over the school-funding controversy, but it was generally thought not to apply to "nonsectarian" exercises like Bible reading and school prayer. ${ }^{54}$ The principle was, to borrow from historian Bruce Dierenfield, "soft on prayer, tough on money" when applied to public schools. ${ }^{55}$ Catholics continued to complain, but not much changed until the dissenters became too loud, and numerous, to ignore. ${ }^{56}$

\section{B. The Rise of Religious Pluralism}

From the start, Protestantism had been the dominant cultural conception of America's religious identity, the nation's de facto religious establishment after

50. See Boles, supra note 31 , at 31 (noting the Blaine Amendment's passage in the House by a vote of 180 to 7 ); GREEN, supra note 31 , at 220 (noting that the Blaine Amendment came four votes short of the necessary two-thirds in the Senate).

51. Seventeen states already had no-funding provisions in their constitutions by the time the Blaine Amendment was proposed in 1876, and another twenty-one states would adopt such provisions after 1876 . Green, supra note 49 , at 299; see Klarman, supra note 26 , at 53; see also Browv, supra note 34, at 57-67 (listing twenty-nine state statutes enacted since 1850 forbidding sectarian religious instruction in publicly funded schools); id. at $103-$ 19 (listing forty-six statc constitutional provisions forbidding the same). For a primer on the history, language, and operation of state Blaine Amendments, see Kyle Duncan, Secularism's Laws: State Blaine Amendments and Religious Persecution, 72 FordHAM L. REV. 493 (2003).

52. See Boles, supra note 31, at 32 (discussing federal legislation requiring new states to adopt irrevocable ordinances that provided "for the establishment and maintenance of a system of public schools which shall be open to all the children of said state and free from sectarian control" (internal quotation marks omitted)).

53. See Noan Feldoman, Dividid by God: america's Church-State ProhlemAND WHAT WE SHOULD DO ABOUT IT 85 (2005) ("Catholic objections that nonsectarianism did not include them were met with little more than the naked insistence that it did.").

54. The Senate version of the Blaine Amendment made this point explicitly. See 4 CONG. REC. 5453 (1876) ("This article shall not be construed to prohibit the reading of the Bible in any school or institution ... ."); see also BOLES, supra note 31 , at 48 ("The majority of states ... tended to regard Bible reading without comment, as nonsectarian religious or moral instruction."); Green, supro note 49, at 293-94 (discussing popularization of the idea of separation of church and state).

55. Die,RENFIELD, supra note 14, at 31.

56. Only two state courts ruled against Bible reading and/or school prayer prior to 1910. See Bd. of Educ. v. Minor, 23 Ohio St. $211,238,241-43$ (1872) (upholding an 1869 decision by the Cincinnati school board to abolish Bible reading and school praycr in public schools); State ex rel. Weiss v. Dist. Bd., 44 N.W. 967, 976 (Wis. 1890) (striking down Bible reading in public schools under the state constitution). 
formal disestablishment. ${ }^{57}$ That conception changed sometime between 1880 and 1930, when approximately 27 million newcomers arrived on America's shores. ${ }^{58}$

The influx of Catholics alone was staggering. In 1850, the Catholic population in the United States was around 1.6 million. ${ }^{59}$ By 1900, it was 12 million, and by 1930 , it was 24 million. ${ }^{60}$ By the mid-1950s, the Catholic population was more than 31 million, and Catholicism was the single largest denomination in the United States. ${ }^{61}$

That said, the impact of Catholics on America's sociopolitical landscape was not just about the numbers. Catholic immigrants assimilated rapidly, coming into their own by the 1920 s and 1930 s with substantial social and economic clout. ${ }^{62}$ With that clout came political power as well-power to decide elections, power to hold cabinet positions, and power to secure state aid for parochial schools on matters such as textbooks and bus transportation. ${ }^{63}$

These developments, in turn, led to a second spike in Catholic-Protestant tensions by the late $1940 \mathrm{~s}^{64}$-this time a reflection of Protestant "status anxiety" over Catholic power in a pre-Vatican II world. ${ }^{65}$ Once again, the tension galvanized popular support for the separation of church and state. ${ }^{66}$ It was dur-

57. Formal disestablishment of religion occurred in the states between 1776 and 1883 ; this is what Steven Green calls the "first disestablishment." The transformation he calls the "second disestablishment" is the subject of this Part-the fall of the de facto Protestant establishment that remained. See Green, supra note 49, at 280-84 (discussing both). For an excellent discussion of the second disestablishment, see generally STEVEN K. GreEN, ThE SeCond Disestablishment: Church and State in Nineteenth-Century America (2010).

58. SOLOMON, supra note 31 , at 127.

59. Jeffries \& Ryan, supra note 26 , at 299.

60. $I d$. at 299-300. Measured in percentage terms, Catholics went from around $5 \%$ of the total population in 1850 to around $17 \%$ by 1906 ; they would remain at $16 \%$ for the next two decades. ROGER FINKE \& RODNEY STARK, THE CHURCHING OF AMERICA, 1776-1990; WINNERS AND LOSERS IN OUR RELIGIOUS ECONOMY 112-13 (1992).

61. See Six out of Ten, NEwSWEEK, Aug. 30, 1954, at 57, 57.

62. As Michael Klarman has discussed, World War I and the integration and growth that followed in the interwar period directly contributed to this phenomenon. See Klamnan, supra note 26 , at $50-53$.

63. By 1947, twenty-two states authorized the public funding of bus transportation to parochial schools. Id. at 52-54 (discussing various manifestations of political power).

64. See Berg, supra note 34, at 333-34. For a famously nativist response, see Paul BlanshaRd, AmERICAN FReEDOM ANd CATHOLIC POWER (1949).

65. Thomas C. Berg, Anti-Catholicism and Modern Church-State Relations, 33 LoY. U. ChI. L.J. 121, 132-38 (2001) (quoting Richard E. Morgan, The Politics of Religious CONFLICT: CHURCH AND STATE IN AMERICA 27 (1968)) (intemal quotation marks omitted) (discussing the reasons for heightened anti-Catholic fears in the 1940s, including the Catholic Church's stance on various issues prior to the announcement of the Second Vatican Council in 1959); see Berg, stupra note 34, at 334 (same).

66. See John T. MCGreevy, Catholicism and American Freedom: A History 168 (2003) (discussing "mid-twentieth-century fears of Catholic power" and their influence on "postwar American liberalism," which "included the insistence that religion, as an entirely 
ing this time that the Supreme Court incorporated the Establishment Clause into the Fourteenth Amendment's due process protections, constitutionalizing the "wall of separation between church and State" that had come to epitomize proper church-state relations (and the standard response to Catholic demands) for over a hundred years. ${ }^{67}$

Compared to Catholics, Jews constituted a relatively tiny portion of the population in the United States-just $0.5 \%$ in the 1880 s and $3 \%$ by $1930^{68}$ but they, too, were quick to assimilate and establish themselves in positions of influence and power. ${ }^{69}$ Then came the Holocaust. Americans saw the unspeakable atrocities of extreme anti-Semitism and made a sharp ideological turn. ${ }^{70}$ American anti-Semitism, which had been rampant in the 1920s and 1930s (itself a response to rising Jewish influence and power) fell dramatically. ${ }^{71}$ And Jewish claims of religious freedom "gained special resonance" with the American public. ${ }^{72}$ Jews may not have had the numbers, but as John Jeffries and Jim Ryan put the point, they "laid an equal claim to America's conscience." "73

The nation's newfound sensitivity to Jewish claims of religious freedom likewise posed a problem for religious observances in public schools, which alienated Jews even more than Catholics. ${ }^{74}$ Jews did not recognize the New

private matter, must be separated from the state'); Berg, supra note 65 , at $122,124-26,147$ 48 (discussing the best-seller status and rave reviews of Paul Blanshard's book, BLANSHARD, supra note 64 , and popular support for the separation of church and state as a response to the threat of Catholic power); Sarah Barringer Gordon, "Free" Religion and "Captive" Schools. Protestants, Catholics, and Education, 1945-1965, 56 DEPAUL L. REV. 1177, 1178-79, 1192 , 1205 (2007) (discussing how the discovery of "captive schools" in the late 1940s-schools that were public but infused with parochial markings, often with nuns teaching in full habit-galvanized Protestant politicism in support of the separation of church and state).

67. Everson v. Bd. of Educ., 330 U.S. 1, $15-18$ (1947) (quoting Reynolds v. United States, 98 U.S. 145, 164 (1879)) (internal quotation mark omitted) (incorporating the Establishment Clause and endorsing a strong separation of church and state while upholding public funding of bus transportation to parochial schools); see Illinois ex rel. McCollum $\mathrm{v}$. Bd. of Educ., 333 U.S. 203, 205-06, 212 (1948) (invalidating an early-release program for religious instruction on school grounds). As Thomas Berg has explained, disestablishment had been viewed as a fundamental right since the antebellum period, so incorporation had little immediate effect and was treated by the Justices in Everson as almost a given. See Berg, supra note 34 , at 307-12.

68. Klarman, supra note 26 , at 49 . In terms of sheer numbers, the Jewish population in the United States was less than 250,000 in the 1880 s, and just over 4.2 million in 1927. Id.

69. See id. at 51-53 (discussing the economic strides of the Jewish population and the concomitant social and political gains) Semitism)

70. See id. at 54-56 (discussing Americans' ideological turn in response to Nazi anti-

71. See id

72. Jeffries \& Ryan, supra note 26 , at 308 .

73. $I d$.

74. See SoLomon, supra note 31 , at 158 (quoting a rabbi as stating in the Schempp trial, "I don't want to step on anybody's toes but the idea of God having a son is, from the viewpoint of Jewish faith, practically blasphemous" (internal quotation marks omitted)). 
Testament, which meant they did not recognize the Lord's Prayer. ${ }^{75}$ In fact, they did not recognize much of anything about Horace Mann's compromise approach to Christianity - they weren't Christian.

By the mid-twentieth century, Protestants could no longer claim a preeminent position in the nation's faith hierarchy; the reign of Protestantism as America's de facto religious establishment had come to an end. ${ }^{76}$ In its place, the "three great faiths"-Protestantism, Catholicism, and Judaism-emerged as the dominant religious identities in America, ${ }^{77}$ and even they had to make room. By the mid-1950s, eighteen religious denominations had over a million members, ${ }^{78}$ while eighty-three had more than 50,000 members. ${ }^{79}$ Pluralism reigned.

With the rise of religious pluralism came two sociopolitical responses. One was an interest in religious toleration, accommodation, and standardization. This was the 1950s ecumenical movement, the same force that produced the National Council of Churches and numerous other interdenominational organizations during this time ${ }^{80}$ "Modern man .... feels that people should have denominational connections, but also a deep sense of religious give-and-take for the beliefs of others," wrote Better Homes and Gardens in 1956, adding that the concept of "ecumenicity, which means universality, is now in operation." 81

75. See Robert L. Cord, Separation of Church and State: Historical Fact and CURrent Fiction 162 (1982) ("The 'Lord's Prayer" is distinctively a Christian prayer, the most commonly used recitation of which is found in the New Testament Gospel attributed to Matthew.").

76. See Jeffries \& Ryan, stpra note 26 , at 297 ; Klarman, supra note 26 , at 56-58.

77. See Will Herberg, Protestant-Catholic-Jew: An Essay in american Religious Sociology 53-54 (1955); Richard E. Morgan, The Supreme Court and RELIGION 125 (1972) ("[T]he mid-1940's was increasingly referred to as a distillation of "Three Great Faiths."). For a discussion of the term "Judeo-Christian" as the "new national creed" by the early 1950s, see Mark Silk, Spiritual Polit]cs: Religion and America SINCE WORLD WAR II, at 40-53 (1988).

78. Six out of Ten, supra note 61 , at 57 .

79. Sch. Dist. of Abington Twp. v. Schempp, 374 U.S. 203, 214 (1963) (noting census data); see also FINKE \& STARK, supra note 60, at 199 (noting the existence of 258 separate church denominations in America as of 1959).

80. See Roswell P. Barnes, The Ecumenical Movement, 332 ANkaLs AM. ACAD. POL. \& Soc. SCl. 135, $136(1960)$ (" $[T]$ he ecumenical movement is the trend toward unity among the Christians of the world. . . The movement is much broader than its organized manifestations."); Marcus Bach, What's Happening on Church Street, US.A.?, BETTER HOMES \& GARDENS, Oct. 1956, at 74, 154 (discussing the thirty-denomination National Council of the Churches of Christ, sixty-denomination National Association of Evangelicals, and over-fiftydenomination American Council of Christian Churches); The Spirit: A Time to Be Stern, NEwSWEEK, Dec. 14, 1959, at 121, 122 (predicting that "the ecumenical movernent will continue to flourish"). For additional contemporary discussions of the ccumenical movement, sce generally The ECUMENICAL ERA IN CHURCH AND SOCIETY: A SymposIUM IN HONOR OF John A. Mackay (Edward J. Jurji ed., 1959); and Robert LeE, The Social Sources of CHURCH UNTT: AN INTERPRETATION OF UNITIVE MOVEMENTS IN AMERICAN PROTESTANTISM (1960).

81. Bach, supra note 80, at 154 (emphasis omitted). 
What the ecumenical movement brought was what religious pluralism arguably required: building bridges between religions rather than disparaging differences.

Naturally, not everyone agreed. While ecumenicals celebrated being "interreligious in the best American tradition,"82 traditionalists lamented the ecumenical movement as a step toward civic religion-"religion-in-general, superficial and syncretistic, destructive of the profounder elements of faith." ${ }^{83}$ Some things were simply too important for give-and-take.

The second sociopolitical response, which was fueled in part by dissatisfaction with the first, was public secularism-a natural extension of the principle of separation of church and state that had long been in play. This sort of secularism was neither anti-Catholic nor antireligious. It was instead a view that the perils of religious pluralism were best navigated by creating room: move religion out of shared space, where it was sure to offend, and into the private sphere, where its expression was most sincere and its practice least encumbered by the need to accommodate others. ${ }^{84}$

Naturally, this separatist response also assuaged lingering fears about Catholic power. John F. Kennedy's successful 1960 presidential campaign was a testament to this power, along with the need to assure the public that it would not be put to Catholic use. In a 1960 speech, Kennedy put the matter to rest using the principle Americans had come to know and trust:

I believe in an America where the separation of church and state is absolute ....

1 believe in an America that is officially neither Catholic, Protestant nor Jewish ... - where no religious body seeks to impose its will directly or indirectly upon the general populace .... the state...

... No religious group should be given special preference or advantage by

In a land where pluralism reigned, Kennedy and others believed that the best stance the state could take toward religion was no stance at all.

The same two responses--ecumenicalism and public secularism-were also playing out in America's public schools, where the pressures of religious pluralism made even "lowest common denominator" Protestant practices deeply problematic. By 1962, when the Supreme Court decided Engel, 9 states no

82. Id.

83. Perils of Freedom, TME, Aug. 4, 1958, at 53, 53 (internal quotation mark omitted) (quoting William Lee Miller, a Presbyterian and a professor of divinity at Yale).

84. See Jeffries \& Ryan, supra note 26 , at 281, 308-11.

85. Senator John F. Kennedy, Speech to Protestant Ministers and Laymen on Religion (Sept. 12, 1960), reprinted in Both Sides of the "Catholic Issue," U.S. NEWS \& WORLD REP., Sept. 26, 1960, at 74, 79 . 
longer allowed religious observances in public schools, ${ }^{86}$ and where allowed, ${ }^{87}$ the practice in large parts of the country had already died out on its own. ${ }^{88}$ Even the 12 states that required school religious observances in 1962 presented a complicated picture. In almost all of those states-11 of the 12--legislation requiring religious observances was passed in an apparent (and sometimes explicit) attempt to entrench such practices before the pressures of religious diversity led school boards to abandon them. ${ }^{89}$ The status quo was on its heels.

The regional variance was just as one might expect. In the South, $89 \%$ of public school districts practiced religious observances prior to Engel, no surprise for a region known as the Bible Belt. ${ }^{90}$ And in the Northeast, $80 \%$ of public school districts did so-again no surprise given the region's deeply religious colonial customs. ${ }^{91}$

Outside these two areas of the country, however, a different baseline prevailed. In the Midwest, only $26 \%$ of public school districts practiced religious observances, while in the West, only $9 \%$ did so. ${ }^{92}$ Indeed, a number of commentators in the 1950s and early 1960 s described America's schools as largely secularist, "even militantly so." 93 In parts of the country, they were wrong about that. But in much of the country, they were right.

86. See DELFATTORE, supra note 36, at 53 (listing the states that had already forbidden religious observances in school at the time of Engel as Alaska, Arizona, California, Illinois, Louisiana, Nebraska, Washington, Wisconsin, and Wyoming).

87. In 1962, 25 states allowed Bible reading either officially or through silence on the subject. See SOLOMON, supra note 31, at 129-30.

88. See Bruce T. Murray, Religlous Liberty in America: The First amendment in Historical and Contemporary Perspective 98 (2008) ("But as immigration continued, pressure from the increasingly diverse population mounted on public schools, and administrators voluntarily began eliminating Bible study."); Berg, supra note 26, at 196 ("But recognition was also growing that such exercises were religiously partial, which occasionally led courts to invalidate them-and more often led school districts to discontinue them.").

89. See Solomon, supra note 31, at 129-30 (discussing Pennsylvania's 1913 mandatory Bible reading statute, passed "to preserve at least this last remnant of religion in the schools against the tide of immigrants," and the similar state statutes that followed "to enshrine the practice in law before local school boards could do away with it under the pressure of religious diversity"). As one supporter of legislation supporting mandatory Bible reading stated, "[W]e are seeking no change. We are resisting a change which amounts to a revolution." GREEN, supra note 31, at 237-38 (internal quotation mark omitted) (concluding that "[w] itnesses and observers alike understood the proposal for what it was: an effort not simpIy to forestall the secularization of public education but to reverse it").

90. SoLOMON, supra note 31, at 130; see also H. Frank Way, Jr., Survey Research on Judicial Decisions: The Prayer and Bible Reading Cases, 21 W. PoL. Q. 189, 199 (1968) (discussing regional variances).

91. SoLomon, supra note 31 , at 130; see also Way, supra note 90 , at 199.

92. SOLOMON, supra note 31 , at 130.

93. Will Herberg, The Sectarian Conflict over Church \& State: A Divisive Threat to Our Democracy?, 14 CommeNTARY 450, 451 (1952) ("[P]ublic school education . . . is no longer religious, neither Catholic, nor Protestant, nor Jewish; it is, by and large, secularist, even militantly so."); see also VIRGIL C. Blum, Freedom of CholCE IN EduCATION 109 (1958) ("The state is imposing the secularist religion upon all public school children."); 
Where religious observances remained in America's schools, the ecumenical movement began watering down what was left. The school prayer at issue in Engel-called the "Regents' Prayer" for the New York Board of Regents that adopted it ${ }^{94}$ - provides a rich example of this phenomenon. The Regents' Prayer was the product of an interdenominational committee whose mission was to draft a nonsectarian, ecumenical prayer to support the spiritual and moral development of children in New York's public schools. ${ }^{95}$ At just twenty-two words, it is worth repeating in full: "Almighty God, we acknowledge our dependence upon Thee, and we beg Thy blessings upon us, our parents, our teachers and our Country." 96

When the Regents' Prayer was proposed in 1951, critics called it "an empty formality with little, if any, spiritual significance," a prayer so devoid of content that it might just work against the inculcation of faith. ${ }^{97}$ Echoing the point, Yale Law School professor Louis Pollak later blasted the Supreme Court's decision to grant certiorari in Engel, writing in the Harvard Law Review in 1963:

New York's attempt to write a prayer had produced such a pathetically vacuous assertion of piety as hardly to rise to the dignity of a religious exercise. The Court might very reasonably have decided to save its scarce ammunition for a prayer that soared, rather than squander it on New York's clay-footed pigeon.

Robert Coughlan, Religion and the Schools, LIFE, June 16, 1961, at 110, 121 ("Bible-reading has disappeared from a majority of the public schools. For practical purposes the secularization of the American public school is very far advanced."); Engel v Vitale, NEW REPUBLIC, July 9, 1962, at 3,4 ("By and large public schools have in recent years tried to be not only non-denominational but secular.").

94. See Engel v. Vitale, 370 U.S. $421,422-23$ (1962).

95. See id.; DELFATTORE, stupra note 36, at 69 ("[T] ]he New York State Board of Regents, which oversees public education in that state, appointed a committee of Protestant, Catholic, and Jewish clergy to compose a prayer. ... [T] he Regents asked the committee to be sure that the prayer was devoid of sectarian doctrine and entirely inoffensive.").

96. Engel, 370 U.S. at 422 (internal quotation marks omitted).

97. Editorial, Prayers in Public Schools Opposed, 69 ChristLan Century 35, 35 (1952) (" $[A] \mathrm{n}$ observance of this sort is likely to deteriorate quickly into an empty formality with little, if any, spiritual significance. Prescribed forms of this sort ... can actually work against the inculcation of vital religion."); see also Parochial Puzzle, TME, May 18, 1959, at 80,83 (quoting a critic as stating, "I consider religion to be much too important in human history to see it reduced to a patriotic exercise in the classroom" (internal quotation marks omitted)); "To Stand as a Grarantee," TimE, July 6, 1962, at 7, 7 (discussing denouncements of the Regents' Prayer when it was adopted, including the claim that it was "an abomination" because it did not mention Christ (internal quotation marks omitted)). As one theologian stated, "A prayer which is the product of a blind, sentimental enthusiasm and therefore conceals or smoothes over differences in themselves divisive is indefensible... . To portray God, in prayer, as the good-natured old man accessible to all on any terms is to bely the Father of our Lord, Jesus Christ." To Pray or Not to Pray, TIME, Aug. 8, 1960, at 63, 63 (internal quotation mark omitted).

98. Louis H. Pollak, The Supreme Court 1962 Term-Foreword: Public Proyers in Public Schools, 77 HARv. L. Rev. 62, 63 (1963). 
Students had said that school prayer was like "peeing-you just do it; it has no meaning." 99 And ecumenical "to whom it may concern" recitations like the Regents' Prayer in Engel were making it worse. 100

In short, the rise of religious pluralism made school prayer an intractable problem by 1962 . Mid-twentieth-century America had too many religions to devise a prayer that would suit everyone--and the harder one tried, the closer one came to a perfunctory ritual that was more trouble than it was worth. As a state-sponsored religious exercise, school prayer had become (to borrow from a 1970 s tune) "too much, too little, too late."101

\section{The Fall of Cold War Religiosity}

Thus far, I have framed Engel in light of the religious diversity that marked mid-twentieth-century America. But at the same time that pluralism was making its mark on the sociopolitical landscape, another force was making a mark of its own: the Cold War. The Cold War figures prominently in the story of $E_{n-}$ gel in two ways. First, the Cold War replaced concerns about Catholic power with concerns about Communist power, easing interfaith tensions at home. ${ }^{102}$ Indeed, Cold War nationalism is almost certainly what gave rise to the ecumenical movement in the first place. ${ }^{103}$ Second, and the focus of the discussion

99. DIFRENFIELD, supra note 14, at 164 (internal quotation marks omitted) (quoting Ellory Schempp); see also id at 95 (quoting Steven Engel as being opposed to the prayer becausc "[i]t"s sacred, and when you rattle these things off and they have no meaning to it at all, I mean, you vitiate the value of religion" (internal quotation mark omitted)).

100. Id. at 130 (referring to Justice Black's view of the Regents" Prayer as "a bland entreaty addressed "to whom it may concern").

101. The phrase is common, but at the risk of revealing my nordy penchant for $1970 \mathrm{~s}$ music, I confess that it was the 1978 duet by Johnny Mathis and Deniece Williams that brought it to mind. If church leaders had written a farewell ballad to school prayer, the opening lines to this 1978 hit are just what they would have said. For those too young (sadly) to know what I am talking about, see Chinaz02007, Johnny Mathis \& Deniece Williams-Too Much Too Little Too Late, YouTuBE (Apr. 18, 2007), http:/www.youtube.com/watch?v=IM 39yIKoSo4. See also DELFATTORE, stupra note 36, at 71 (noting "competing assertions that the Regents' Prayer included too much doctrine to be nonsectarian and too little to be meaningfiul').

102. See Richard Hofstadter, The Paranoid Style in American Politics and OTHER ESSAYS 80 (1965) ("[I]n the grand ecumenicism of their anti-Communist passion they welcome all allies. They are particularly happy to have made terms with the Catholics .... That the Whore of Babylon now sits in Moscow, not Rome, is to their incalculable advantage, for they have been able to turn a powerful domestic foe, the Church, into an al$1 \mathrm{y} . . . \mathrm{m})$.

103. It is hard to imagine that the ecumenical movement's timing in the 1950 s was mere fortuity. What does society do when religion is of utmost importance, but pluralism reigns? It finds a way to make room, which is what the ecumenical movement was all about. For an illustration of this phenomenon, see President-elect Eisenhower's famous statement from 1952, "[O]ur form of government has no sense unless it is founded in a deeply felt religious faith, and I don't care what it is." President-Elect Dwight D. Eisenhower, Eisenhower Address (Dec. 22, 1952), reprinted in N.Y. HeRALJ TRIB., Dec. 23, 1952, at 8. 
here, the Cold War brought with it a surge in religiosity, rendering anything religious virtually unassailable for almost a decade.

By the early 1950s, the Cold War was cold indeed. McCarthyism gripped the country, triggering a Red Scare as intense fears of Communist control and influence dominated the American psyche. ${ }^{104}$ Obsessed with distinguishing themselves from "godless communism," 105 Americans flocked to the one thing that proved democracy different, as well as right and true-religion.

Religion was the place where American patriotism played out in the $1950 \mathrm{~s} .{ }^{106}$ It was the embodiment of American identity, proof positive of democracy's virtue. As one magazine put the point, "Religion in America is an endorsement of the American way." 107

And what an endorsement it was. In the mid-1950s, Congress adopted "In God we trust" as the national motto, ${ }^{108}$ instituted a national day of prayer, ${ }^{109}$ and added the words "under God" to the Pledge of Allegiance. ${ }^{110}$ The President held prayer breakfasts. ${ }^{111}$ Church membership soared. ${ }^{112}$ And school prayer

104. For a primer on McCarthyism and American anti-Communism more generally, see ELLEN SCHRECKER, MANY ARE THE CRIMES: MCCARTHYISM IN AMERICA (1998).

105. Thomas Aiello, Constructing "Godless Communism": Religion, Politics, and Popular Culture, 1954-1960, Americana: J. Am. Popllar Clilture (1900-Present) (Spring 2005), http:/www.americanpopularculture.com/journal/articles/spring_2005/aiello htm; see also DIERENFIELD, supra note 14, at 68 (noting that the govemor of New York, Thomas Dewey, "quickly endorsed" the Regents' Prayer "as an essential means of defeating 'the slave world of godless communism"'); Frank J. SORAUF, The WaLl OF SEPARATION: The Constitutional POLITICs of ChuRch and STaTe 13 (1976) ("[T] he enemy came to be known-positively, if a bit redundantly-as "godless atheistic communism."').

106. See DELFATTORE, supra note 36, at 68 ("Since the Soviet Union was closely identified with atheism while most Americans considered themselves a religious people, belief in God came to symbolize the difference between democracy and totalitarianism."); DIERENFIELD, supra note 14, at 64-65 ("For many Americans, the best defense against Soviet aggression was not political, economic, or even military mobilization, but open expression of religious conviction."). For a vivid example of how Cold War religiosity drove forcign policy decisions, at times with disastrous results, see SETH JACOBS, AMFRICA'S MIRACLE MAN IN VIETNAM: NGo DINH DiEM, Religion, RaCE, AND U.S. INTER VENTION IN SOUTHEAST ASIA, 1950-1957 (2004).

107. Bach, supra note 80, at 74; see also SARAe BARRINGER Gordon, THE SPIRIT OF THE LAW: RELIGIOUS VOICES AND THE CONSTITUTION IN MODERN AMERICA 54 (2010) ("By the 1950s, the 'American Way' was anchored firmly to the three great religious groups in America.").

108. See Act of July 30, 1956, Pub. L. No. 84-851, 70 Stat. 732 (codificd as amended at 36 U.S.C. $\$ 302(2013)$ ).

109. See Act of Apr. 17, 1952, Pub. L. No. 82-324, 66 Stat. 64 (codified as amended at 36 U.S.C. $\$ 119$ ).

110. See Act of June 14, 1954, Pub. L. No. 83-396, 68 Stat. 234 (codifted as amended at 4 U.S.C. \$ 4 (2013)). President Eisenhower signed the bill on June 14, 1954-Flag Day. GoRDON, supra note 107, at 47 ,

111. See Smith, supra note 26, at 951. The National Prayer Brcakfast "has taken place since 1953 and every U.S. president since Dwight D. Eisenhower has participated in the 
was conducted in new, previously secular areas of the country. ${ }^{113}$ Religious books became best sellers-including 1952's Revised Standard Version of the Bible ${ }^{114}$-and "Dial-a-Prayer" became so popular that telephone companies had to add extra lines. ${ }^{115}$ In 1954, Ideal Toy Company announced a new product in response to "the resurgence of religious feeling and practice in America today": a doll with jointed knees so it could pray, ${ }^{116}$ In the mid-1950s, a whopping ninety-six percent of Americans professed to have faith in God, rendering religion not just a belief but a national phenomenon as well. ${ }^{117}$

Given the surge in Cold War religiosity, it is hard to imagine the Supreme Court invalidating school prayer in the $1950 \mathrm{~s}$, or any other religious practice for that matter-and it didn't. From 1953 to 1961, the Court did not decide a single First Amendment case in the area of religion. ${ }^{118}$ Indeed, the Justices passed by opportunities to strike down school religious observances in 1952 and $1954,{ }^{19}$ when doing so would have taken real judicial courage. Prior to Engel, the Court's last word on religion in school was 1952's Zorach v. Clauson, which upheld early-release programs for off-site religious study. ${ }^{120}$ Ironically, it was Justice Douglas, a staunch supporter of the separation of church and state, who penned the opinion's famous line, "We are a religious

breakfast." Macon Phillips, "This Is My Hope. This Is My Prayer.," WHITE House BLoG (Feb. 5, 2009, 12:08 PM EST), http://www.whitehouse.gov/blog_post/this_is_my_prayer.

112. Mighty Wave over the U.S., LIFE, Dec. 26, 1955, at 46, 46-47 ("Nearly 100 million Americans-three of every five-belong[] to some Christian church."); Task for the Churches, NEwSWEEK, Jan. 5, 1959, at 65, 65 (noting that church attendance in 1958 was at an "all-time high" of "50.5 million adults in an average week"); Jonah B. Wise, Survey of a Half Century of Religion, N.Y. TMES, Dec. 12, 1954, § 6 (Magazine), at 17 (comparing the percentage of the population having membership in religious institutions over the first several decades of the twentieth century and noting the midcentury spike).

113. See Sorauf, supra note 105, at 14.

114. See Eugene Carson Blake, Is the Religious Boom a Spiritual Bust?, Look, Sept. 20, 1955, at 27, 29 ("More than one million copies of the Revised Standard Version of the Bible were sold in its first three months of publication."); see also SORAUF, supra note 105, at 13 (noting that four of 1953's top ten sellers were religious books and that seven religious leaders graced the cover of Time magazine between 1951 and 1954).

115. See Dial a Prayer, Newsweek, July 4, 1955, at 23, 23.

116. Words \& Works, TJME, Sept. 20, 1954, at 65, 65 (internal quotation marks omitted).

117. See DierENFIELD, stpra note 14, at 65 (discussing the results of a 1957 Gallup poll and its breakdown of formal religious affiliations between Protestants, Catholics, and Jews); Blake, supra note 114, at 29 ("'I've got religion' has become a national phenomenon.").

118. See Laubach, supra note 38 , at 39.

119. See Gideons Int'1 v. Tudor, 348 U.S. 816 (1954), denying cert. to Tudor v. Bd. of Educ., 100 A.2d 857 (N.J. 1953); Doremus v. Bd. of Educ., 342 U.S. 429, 432-33 (1952) (dismissing appeal for lack of standing because by the time the case reached the Supreme Court, the plaintiff's child had graduated, leaving only taxpayer status as a basis for standing, which the Court held was insufficient).

120. 343 U.S. $306,311-12$ (1952). 
people whose institutions presuppose a Supreme Being." 121 In the early to mid1950 s, that was ail one needed to say.

But the world was a different place by 1962 . The Cold War continued with the Berlin crisis, the Bay of Pigs invasion, and, after Engel, the Cuban Missile Crisis, ${ }^{122}$ but by the late 1950 s, McCarthyism was dead (as was McCarthy himself) ${ }^{123}$ and religiosity had peaked. Contemporary commentators pegged 1958 as the year that Cold War religiosity began to wane, ${ }^{124}$ and the difference was palpable. In 1955, Newsweek had reported on the resurgence of religiosity in America, noting that "[a]n attack on religion is regarded by most Americans as an attack on the basic values by which the nation lives." 125 In 1959, the same magazine reported on the reemergence of religious criticism in America, noting that "[r]eligion always grows fat and vulgar and obscene when its strength is unquestioned." 126 By 1962, commentators were questioning whether there had been a religious revival at all, surmising that religion had just been a proxy for anti-Communist sentiment. ${ }^{127}$ Whatever it was, it was on the decline by the late 1950 s, giving the Justices what they needed most to take another First Amendment religion case-room.

\section{For the Justices, a Relatively Easy Case}

For engendering so much controversy, Engel was remarkably tuncontroversial among the Justices who decided it. The Supreme Court was down two members at the time-Justice Frankfurter had collapsed just days after oral arguments in the case, and Justice White, who had been nominated to fill Justice

121. Id. at 313. The irony did not go unnoticed. See id. at 325 (Jackson, J., dissenting) ("Today's judgment will be more interesting to students of psychology and of the judicjal processes than to students of constitutional law."). For Justice Douglas's expression of his staunchly separatist views in Engel, see notes 227-29 and accompanying text below.

122. See generally MARTN WALKER, THE COLD WAR: A HistoRY (1993). The Cuban Missile Crisis occurred in October 1962. See id. at 171. Engel was decided in June.

123. The Senate censured McCarthy in December 1954. See MCCarThyism: THE Great AMERICAN RED SCARE 178, 179-80 (Albert Fried ed., 1997) (discussing McCarthy's censure in 1954 and death in 1957).

124. See Task for the Churches, supra note 112, at 65 (describing 1958 as "the year when "the "revival of religion" had begun to wane" (quoting Editorial, The Year the Revival Passed Crest, 75 Christian Century 1499, 1499 (1958))).

125. Americans and Religion: State of the New Revival as Billy Graham, Niebuhr, and LaFarge See It, NewsweEK, Dec. 26, 1955, at 44, 44.

126. See Task for the Churches, supra note 112, at 65 (quoting Editorial, supra note 124 , at 1500 ).

127. See, e.g., Editorial, Keeping the Pews Filled, 192 NaTION 491, 491 (1961) ("There has not been a religious or spiritual revival; more people have attended church merely because it was the correct thing to do, showed one's opposition to atheistic communism, and gave one a certain social status."). 
Whittaker's open seat, had not yet been confirmed. ${ }^{128}$ But the Court in Engel had little trouble deciding the case without them. The Justices voted to strike down the prayer 6 to 1, and even Justice Stewart, the lone dissenter, was initially undecided. ${ }^{129}$ Conservative Justices Harlan and Clark both voted with the majority in Engel, and Justice Frankfurter, who led the conservative bloc, had stated his intention to vote that way as well. ${ }^{130}$ With even the conservatives in agreement, the Justices did not need a full bench to strike down school prayer. As far as Supreme Court controversies went, Engel was a relatively easy case.

Granted, the vote in Engel could have disguised a much more difficult decisionmaking process, but notes from the Supreme Court's conference discussions indicate that this was not the case. Engel required little discussion in conference, which began with Chief Justice Warren noting that the state had "practically conceded" a violation of the Establishment Clause. ${ }^{131}$ No one was denying that the Regents' Prayer was a religious exercise-it was prayer, after all-and no one was denying that the state wrote it. ${ }^{132}$ School officials were telling children what to pray, where, and when; even the name of the prayer bore the mark of the state. ${ }^{133}$ The Court's prior Establishment Clause decisions had not been a model of clarity, ${ }^{134}$ but they did not need to be to decide Engel. Whatever else the Establishment Clause prohibited, it at least prohibited the state from drafting a prayer and asking schoolchildren to pray it.

128. See Sam Duker, The Public Schools ani Religion: The legal Context 158 (1966); see also GoLD, supra note 48, at 81 ("On April 5, two days after the arguments had been heard, Frankfurter collapsed at his desk and was rushed to the hospital. After a lengthy leave of absence, ... [he] resigned from the Coutt in August of that year.").

129. See SuPREME Court IN CONFERENCE, supra notc 16 , at 424 (noting that all the Justices in conference voted to reverse except for Justice Stewart, who stated, "I am still in doubt, and am not at rest").

130. See id.

131. Id. (quoting Chief Justice Warren in conference).

132. See Engel v. Vitale, 370 U.S. 421, 424-25 (1962) ("The nature of such a prayer has always been religious, none of the respondents has denied this ... ."); Engel v Vitale, supra note 93, at 4 ("Once having decided to hear Engel $v$ Vitale it is difficult to see how the Court could have reached a substantially differcnt decision. The case posed the clear-cut issue of a prayer drafted by a state government and prescribed by certain local bodies.").

133. See DIERENFIELD, supra note 14, at 91 (quoting one of the plaintiffs in Engel as saying, "My basic feeling was that if the state could tell us what to pray and when to pray and how to pray, that there was no stopping").

134. See Zorach y. Clauson, 343 U.S. 306, 311-12, 315 (1952) (upholding an carlyrelease program for off-site religious study); fllinois ex rel. McCollum v. Bd. of Educ., 333 U.S. 203, 209-10 (1948) (invalidating an early-release program for religious instruction on school grounds); Everson v. Bd. of Educ., 330 U.S. 1, 15-18 (1947) (endorsing strong separation of church and state while upholding public funding of bus transportation to parochial schools); see also William LeE Mil.ter, THE First LiberTY: AMERICA's Foundation IN RELIGIOUS FREEDOM 196-200 (2003) (discussing the incoherence that marked the Supreme Court's three Establishment Clause cases prior to Engel and likening Justice Douglas's position in particular to "the homeward journey of a New Year's Eve reveler"). 
This is not to say there were no arguments the other way. The state had argued that children could be excused from the prayer-and they could, more or less ${ }^{135}$ _but the Justices found the claim inapposite. The problem in Engel was that the state had written the prayer, and excusing those who objected did nothing to change that fact. ${ }^{136}$ Similarly, the Justices rejected the claim that invalidating the Regents' Prayer would deny the free exercise tights of those who wanted to pray. ${ }^{137}$ If students wanted to pray, they could pray, the Justices maintained. What the Establishment Clause forbid was using the arm of the state to help. ${ }^{138}$

If any aspect of Engel was difficult, it was the implications of the case. God's name was on the nation's coins and paper money, in the Pledge of Allegiance, and at the start of new sessions in court-including the U.S. Supreme Court. ${ }^{139}$ Justice Douglas struggled with these line-drawing difficulties, ${ }^{140}$ but among the Justices in the majority, he appears to have been the only one. It was one thing to "speak of God with reverence," Chief Justice Warren reasoned in conference, and quite another to recite a state-composed prayer in school. ${ }^{141} \mathrm{At}$

135. See Brief for Petitioners at 23-24, 31-32, Engel, 370 U.S. 421 (No. 468), 1962 WL 115797 (arguing that because the prayer was only twenty-two words long, nonparticipating students usually stayed in the classroom; indeed, the prayer was about over by the time those who wanted to leave reached the door); Anthony Lewis, The Prayer Decision, N.Y. TLMEs, June 28,1962 , at 17 ("[S]tudents could be excused from participating only at the risk of labeling themselves nonconformists- 'pariahs,' as the complaining parents put it."); see also Editorial, Religious Neturality, WASH. POST, June 18, 1963, at A16 (noting in the wake of Schempp that "even though individual children may be excused from the observance if they are willing to undergo the embarrassment of such nonconformity, the practice entails an inescapable element of coercion"').

136. See Engel, 370 U.S. at 430 . Excusal mattered in the free speech context, see W. Va. State Bd. of Educ. v. Bamette, 319 U.S. 624, 641-42 (1943), but Engel was not a case about free speech - it was about state-sponsored religion. See Oral Argument, supra note 21, at 42:17 (distinguishing Bamette during oral arguments in Engel).

137. See Engel, 370 U.S. at $433-34$ ("It has been argued that to apply the Constitution in such a way as to prohibit state laws respecting an establishment of religious scrvices in public schools is to indicate a hostility toward religion or toward prayer. Nothing, of course, could be more wrong." ).

138. See id.; see also Sch. Dist. of Abington Twp. v. Schempp, 374 U.S. 203, 226 (1963) ("While the Free Exercise Clause clearly prohibits the use of state action to deny the rights of free exercise to anyone, it has never meant that a majority could use the machinery of the State to practice its beliefs.").

139. See Engel, 370 U.S. at 446, 449 (Stewart, J., dissenting).

140. See Memorandum from Justice William O. Douglas to Justice Hugo L. Black (June 11, 1962) (Hugo LaFayette Black Papers, Box 354) ("If, however, we would strike down a New York tequirement that public school teachers open each day with prayer, 1 think we could not consistently open each of our sessions with prayer. That's the kemel of my problem."). All sources in this Article cited to the Hugo Lafayette Black Papers or the Earl Warren Papers are on file with the Manuscript Division of the Library of Congress.

141. See Supreme Court in Confer fnce, supra note 16, at 424 (quoting Chicf Justice Warren in conference as saying, "The fact that we speak of God with reverence does not mean that we can take the prayer into the school"); see also ED CRAY, CHIEF JUSTICE: A 
some point, there would be hard cases, but neither patriotic references to God on the one hand, nor state-composed school prayer on the other, were among them.

The ease with which the Justices decided the case came through in the Engel opinion. "There can be no doubt," key passages began, with the words "of course" sprinkled here and there for good measure. ${ }^{142}$ To the Justices in the majority, Engel was self-evident, a matter of constitutional common sense. That is why, as the Court would later explain, its opinion in Engel did not cite a single case. ${ }^{143}$

But the fact that the Justices saw Engel as a relatively easy case under the law does not mean that the law was all, or even most, of what was driving it. Shortly before Engel was announced, Justice Black gave a candid account of his jurisprudential views in what the press called "one of the most remarkable interviews in judicial history." 144 As to the First Amendment's Establishment Clause, Justice Black said this:

I have to be honest about it. I confess not only that I think the Amendment means what it says but also that I may be slightly influenced by the fact that I do not think Congress should make any law with respect to these subjects.

$$
\begin{aligned}
& \ldots[\mathrm{B}] \text { eing } \\
& \text { the }
\end{aligned}
$$

Justice Black's wife later recounted that separation of church and state was an issue her husband "felt deeply and passionately about" commitment he forged largely from growing up in rural Alabama and experi-

BIOGRAPHY OF EARL WARREN 387 (1997) ("In Warren's mind, it was one thing to invoke God's benevolence, and another to compel that prayer.").

142. See, e.g., 370 U.S. at 424 ("There can, of course, be no doubt that New York's program of daily classroom invocation of God's blessings as prescribed in the Regents' prayer is a religious activity."); id. at $\mathbf{4 3 0}$ ("There can be no doubt that New York's state prayer program officially establishes the religious beliefs embodied in the Regents' prayer."); id. at 433-34 (addressing the claim that striking down the Regents' Prayer would signal hostility toward religion with the answer that "[n]othing, of course, could be more wrong"); id. at $435 \mathrm{n} .21$ ("There is of course nothing in the decision reached here that is inconsistent with the fact that school children and others are officially encouraged to express love for our country by reciting historical documents such as the Declaration of Independence which contain references to the Deity....").

143. See Schempp, 374 U.S. at 220-21 (noting that the principles underlying Engel "were so universally recognized that the Court, without the citation of a single case," issued its ruling).

144. James E. Clayton, Black Answers Critics of 1 st Amendment View, L.A. Times, June 25,1962 , at 16 .

145. Interview by Edmond Cahn with Justice Hugo L. Black in N.Y., N.Y. (Apr. 14, 1962), in Justice Black and First Amendment "Absolutes": A Public Interview, 37 N.Y.U. L. REV. 549, 553-54 (1962).

146. HUGO L. BLACK \& Elizabeth BLACK, MR. Justic: And MRS. Bl.ACK: THE MEMOrRS OF HUGO L. BLACK AND ElZZABETH BlaCK 95 (1986). 
encing firsthand the awesome power of the church in Southern society. ${ }^{147}$ "Prayer ought to be a private thing," Justice Black told his son. ${ }^{148}$ It was, to borrow from the opinion in the case, "too personal, too sacred, too holy" for the state to draft and ask others to recite. ${ }^{149}$

Whether the rest of the Justices in Engel-most of whom were religious, ${ }^{150}$ and some of whom were anti-Catholic ${ }^{151}$-were also moved by their individual views of proper church-state relations (at least at a conscious level) is hard to say. We do know from an early draft of the Engel opinion that the Justices in the majority were thinking about school prayer in practical, as well as legal, terms. Even seemingly all-inclusive prayers were impossibly problematic, the draft stated, explaining:

This case itself shows beyond doubt that New York has not succeeded and cannot succeed in writing an official prayer satisfactory to everybody in the State. Non-believers in the State, as one of the petitioners here is shown to be, certainly cannot conscientiously participate in the prayer. And many devoutly religious people, as other of these petitioners are shown to be, are deeply offended by the practice of publicly reciting a memorized state prayer under the circumstances prevailing in a public school classroom eyen though they strongly believe that everything stated in the prayer is true. ${ }^{152}$

The state would never please everyone, the Justices had come to conclude; the best it could do was to get out of the business of trying.

The same view permeated the cultural backdrop against which Engel was decided. Writing in 1963, Newsweek reported that when the Supreme Court decided Engel, "[t]wo points were widely agreed upon: (1) fostering religion in the young is properly the job of church and home and (2) religious observances which are perfunctory or so watered down as to be offensive to no one are a waste of time for everyone." ${ }^{153}$ Perhaps Newsweek was wrong in that regard,

147. Barbara A. Perry, Jusice Hugo Black and the "Wall of Separation Between Church and State," 31 J. CHuRCH \& ST. 55, 56-59 (1989) (discussing Justice Black's religious background and the role it played in shaping his attitudes about religion); see also DIERENFIELD, supra note 14, at 49 (noting that Justice Black "never forgot how harmful and humiliating religion could be, especially when a local congregation publicly expelled his father and two uncles for imbibing alcohol"').

148. Hugo Black, JR., MY Father: A Remembrance 176 (1975).

149. Engel v. Vitale, 370 U.S. 421, 432 (1962).

150. See Earl Warren, The MEMOIrS OF Earl Warren 316 (1977) ("The majority of us on the Court were religious people, yet we found it unconstitutional that any state agency should impose a religious exercise on persons who were by law free to practice religion or not without state interference.").

151. See Berg, supra note 65, at 129 (discussing the anti-Catholic vicws of Justices Black and Douglas).

152. Hugo L. Black, Draft Opinion at 4-5, Engel v. Vitale, No. 468 (June 25, 1962) (Hugo LaFayette Black Papers, Box 354); see also Letter from Justice Hugo L. Black to Arthur J. Freund (Aug. 10, 1962) (Hugo LaFayette Black Papers, Box 358) ("This experience illustrates the simple truth that it is impossible to find a single prayer that will give full satisfaction to several conflicting religious groups.").

153. Church and State, NEWSwEEK, July 1, 1963, at 48,48 . 
but there is reason to think not. Critics lamented Engel as the product of a "broad public consensus" that religion was a private matter, ${ }^{154}$ and chastised the Supreme Court for forcing by judicial fiat what the country was already in the process of doing on its own. ${ }^{155}$ Even the Board of Regents had issued a statement when it adopted the Regents' Prayer that read, "Formal religion is not to be injected into the public school. It is a matter for the church and the home, for the religious leaders and the parents of each child." ${ }^{156}$ The principle of public secularism had gained widespread acceptance by 1962; it is hard to imagine the Justices not being impacted by those views.

That leaves one final, but critically important, point about where the Justices were coming from in Engel-their utter unawareness of just how unpopular the ruling would be. By all accounts, the Justices were surprised by the hostile reaction to Engel. ${ }^{157}$ Indeed, they found it difficult to fathom how the public could disagree. In a letter to his niece just days after Engel, Justice Black wrote:

The basic premise of the First Amendment is that people must be left to say their prayers in their own way, and to their own God, without express or explicit coercion from any political office holder. There are not many people with religion and intelligence who will think this constitutional principle wrong on mature second thought. 158

154. School Prayer Ban Scored at Red Mass, N.Y. Times, Sept. 21, 1962, at 36 (internal quotation marks omitted) (quoting a Jesuit priest). Not surprisingly, this view was widely shared by supporters of the decision as well. See Editorial, In Behalf of Religion, WasH. Post, June 26, 1962, at A12 ("But religious faith is best inculcated in the home or in places consecrated to religion."); Editorial, supra note 22.

155. See Editorial, Unrealistic and Unwise, CATH. STAR Herald, June 21, 1963, at 6 (Hugo LaFayette Black Papers, Box 355) (" $[R]$ eligious practices have been eliminated more and more over the years. The evidence has been clear that the 'trickling stream' was drying up rather than building up into a potential torrent. Justices should judge with an eye on the times as well as on the lawbooks."). omitted).

156. Brief of Intervenors-Respondents, supra note 21, at 5 (internal quotation mark

157. See CRAY, supra note 141 , at 387 ("Certainly the brethren were unprepared for the public outery that the School Prayer Case provoked."); BERNARD SCHWARTz, SUPER CHIEF; EARL WARREN AND HIS SUPREME COURT--A JUDICIAL BIOGRAPHY 442 (1983) ("Even after all the abuse they had taken during the past decade, Wancn and the Justices were both surprised and pained by the reaction to their decision."); Anthony Lewis, Op-Ed., Public Mood Plays Big Role in Court Rulings, N.Y. TJMES, June 23, 1963, \&4, at 4 ("When the prayer case came along last June few observers expected it to touch a raw nerve in the American politic. The Justices themselves treated it briefly with little of the aura that tends to surround a 'great case."); see also infra notes 262-68 and accompanying text (discussing comments by several Justices that Engel had been grossly misunderstood).

158. Roglr K. Newman, Hugo Black: A BIOGRaphy 523-24 (1994) (reptoducing in part a letter to Hazel Davis). The same sentiment was shared by several school-age boys, whose history teacher wrote to Justice Black to share that "[i]n our class discussion [the students] stated over and over again that they could not understand why something so selfevident needed to have the Supreme Court hand down a decision." Letter from Gordon Reid to Justice Hugo L. Black (Nov. 21, 1962) (Hugo LaFayettc Black Papers, Box 354). 
Justice Black expressed the same sentiment (albeit in a slightly more acerbic tone) when responding to hate mail on Engel. In letter after letter, he sent a curt response like this one:

Your letter indicates to me that you have probably not read [the Engel] opinion and for that reason I am sending a copy of it to you. After you have read it, I would appreciate your writing me what is said in that opinion, if anything, with which you disagree. ${ }^{159}$

Nowhere in the conference notes is there any indication that the Justices in Engel anticipated the possibility of negative public reaction to their ruling, as was the case in Brown v. Board of Education before it, ${ }^{160}$ or Schempp the following year. ${ }^{161}$ To the contrary, one almost gets the sense that the Justices thought they would be applauded for the decision, as had been the case when they protected the free speech rights of religious dissenters in $1943 .^{162}$ Engel's confi-

159. Letter from Justice Hugo L. Black to A.E. Shafer (June 4, 1964) (Hugo LaFayete Black Papers, Box 354); see also Letter from Justice Hugo L. Black to Macy Blanton (July 3, 1962) (Hugo LaFayette Black Papers, Box 357) ("In order that you may see for yourself what the Supreme Court decided and what it did not decide, I am sending you [a] copy of the opinion."); Letter from Justice Hugo L. Black to Mrs. James Burson (Mar. 20, 1963) (Hugo LaFayette Black Papers, Box 354) ("I would suggest that you might get a new insight into the problem about which you wrote me by reading the Court's opinion in that case, a copy of which you will find enclosed. After you have read the full opinion of the Court and the notes I would be glad to have you write me stating with which particular part of the opinion you disagree."); Letter from Justice Hugo L. Black to John W. Davis (Sept. 10, 1963) (Hugo LaFayette Black Papers, Box 354) ("After you have taken time out of your own busy schedule to read these opinions, I shall be very happy to hear from you again."); Letter from Justice Hugo L. Black to Comelia O. Edington (July 26, 1962) (Hugo LaFayette Black Papers, Box 354) ("I believe that if you will read the Court's opinion I am sending you in the Regents' case ... you, like many others who have expressed themselves about the latest opinion, will understand it much better than you have up to this time."); Letter from Justice Hugo L. Black to R.L. Flowers (May 18, 1964) (Hugo LaFayette Black Papers, Box 354) ("Since your letter seems to be based in part upon what you think that case decided, I would like to suggest that you read it."); Letter from Justice Hugo L. Black to Jane Wasson \& Faye Jernigan (July 17, 1962) (Hugo LaFayette Black Papers, Box 358) ("In your letter you referred to the decision as one in which the Court declared 'the use of prayers in public schools unconstitutional.' In order that you may understand what the Court did hold, I am sending you a copy of the opinion and would like to request that both of you read every word in it, including the footnotes.").

160. See Supreme Court IN Conference, supra note 16 , at 648 (reproducing conference notes in Brown v. Board of Education, 347 U.S. 482 (1954), including discussion of possible violence following a ruling holding segregation unlawful),

161. See id. at 426 (reproducing conference notes in School District of Abington Township v. Schempp, 374 U.S. 203 (1963), including discussion of the nced for the public to be reassured).

162. See W. Va. State Bd. of Educ. v. Barnette, 319 U.S. 624, 629, 642 (1943) (invalidating a compulsory flag salute in a challenge by Jehovah's Witnesses); GoRDON, supra note 107, at 46 ("Bamette was greeted with widespread praise."); see also Philip B. Kurland, The Regents' Prayer Case: "Full of Sound and Fury, Signifying ...," 1962 SuP. CT. REv. I, 33 ("It is hard to believe that many who now find this notion [that religion should not be in school] unpalatable will not soon, or eventually, be applauding it.")- 
dent tone. The sense that there was no need to cite precedent. Even Justice Black's comment from the bench while delivering Engel-"[T]he right of the people to pray in their own way is not to be controlled by the election returns"--bore an uncanny resemblance to West Virginia State Board of Education v. Barnette's famous line. ${ }^{163}$

How the South would have figured into the Justices' expectations is hard to say. One would think that the Justices would have known that a region referred to as the Bible Belt would not take kindly to their decision, particularly in the wake of Brown. ${ }^{164}$ And maybe that was true, but the Justices figured they had enough support elsewhere, or just didn't respect the South enough at that time to care. ${ }^{165}$

Yet it is also possible that the Justices did not think the South had a dog in the fight. The petitioners had pointed out that the Regents' Prayer was sui generis; there was not another state-composed prayer in the country. ${ }^{166}$ And the Justices knew that the pious hated the Regents' Prayer as much as religious dissenters did. ${ }^{167}$ In the end, the Justices may have viewed the South as inapposite. The Regents' Prayer was progressive, and progressive prayer was not what the South was about.

Either way, this much was true: Engel was for the Justices a relatively easy case. From the facts, to the law, to the practical considerations and cultural cues-all of the Justices' data points were pointing the same way. And that tells us something else too. Regardless of what they thought about the South, the Justices were utterly unprepared for what happened next.

163. Compare Lewis, supra note 23 (internal quotation mark omitted) (quoting Justice Black's comments from the bench while announcing the Engel opinion), with Barnetie, 319 U.S. at 638 (" $[$ F]undamental rights may not be submitted to vote; they depend on the outcome of no elections.").

164. See supra note 90 and accompanying text (noting that $89 \%$ of school districts in the South practiced religious observances).

165. See Powe, supra note 14, at 204-05 ("[T]he Court could more than balance any opposition to its actions [in Engel] by active support of the most prominent politician in the United States-John Kennedy."); of. Philip B. Kurland, The Supreme Court 1963 TermForeword: "Equal in Origin and Equal in Title to the Legislative and Executive Branches of the Government," 78 HARv. L. REV. 143, 176 (1964) ("The Court has been most fortunate in the enemies that it has made, for it is difficult not to help to resist attack from racists, from the John Birch Society and its ilk, and from religious zealots who insist that the Court adhere to the truth as they know it.").

166. See Brief for Petitioners, supra note 135, at 15 ("Petitioners do not betieve that there is any prayer in use in the public schools of any State in this country which, like the prayer involved in this case, has been composed by State officials for use in such schools. In 1955, a prayer virtually identical with the Regents' Prayer was presented to the Honorable Edmund G. Brown, now the Governor but then the Attoney General of California. ... Governor Brown ruled that the prayer presented to him was a violation of the Establishment Clause of the First Amendment ....").

167. See supra notes 97,152 and accompanying text. 


\section{WHAT HAPPENED NEXT}

Why, if Engel was so right, did it strike the country as so wrong? In this Part, I offer an answer to that question. First, I discuss the nation's reaction to Engel. Then I turn to the role of the media in tanking the decision, and the role of the religious establishment in saving it. I end with a discussion of School District of Abington Township v. Schempp, the 1963 decision that struck down Bible reading and recitation of the Lord's Prayer in public schools. ${ }^{168}$

\section{A. "When We Won the Case, All Hell Broke Loose"}

For the families who filed suit in Engel, the Supreme Court's ruling was a brief moment of elation, ${ }^{169}$ followed by a living nightmare. ${ }^{170}$ For the Supreme Court, it was only the nightmare-a "veritable avalanche" of fury and hate. ${ }^{171}$ Contemporary commentators described the public's reaction to Engel as an "explosion of shock and resentment," 172 a "thunderclap of outrage."173 The country had not seen the decision coming, and the scale of the jolt was enormous. ${ }^{174}$ In terms of sheer volume, the vitriolic attacks on Engel (and the Supreme Court for deciding it) were unlike anything the nation had ever seen. ${ }^{175}$

The first seventy-two hours after Engel were especially intense. Writing for the New York Times, Anthony Lewis reported that "[f]or several days all the serious business of the Congress of the United States was put aside while

168. 374 U.S. 203,223 (1963).

169. Plaintiff Lawrence Roth's response when told the Supreme Court had ruled his way in Engel was "Thank God." SHANE MOUNTJOY, ENGEL V. VITALE: SCHOOL PRAYER AND THE ESTABLISHMENT CLAUSE 104 (2007) (internal quotation thark omitted).

170. See DIERENFIELD, supra note 14, at 138 (discussing harassment of the plaintiffs after Engel, which included "a deluge of 'chilling' hate mail, snubs from erstwhile friends, and telephone threats of job dismissal, arson, and kidnapping"). One plaintiff responded, "I have a feeling of sadness because these are so-called godly people. ... If their God teaches therm to wish my kids get polio and my house be bombed, then I think He hasn't done a very good job with them." The Court Decision-- and the School Prayer Furor, supra note 16, at 44 (internal quotation marks omitted).

171. Julia C. Loren, Engel v. Vitale: Prayer in the Public Schools 60 (2001).

172. Public Fears Diminish that Prayer Will Have Wide Impact, Wall ST. J.-, July 6, 1962 , at 1 .

173. The Court Decision-and the School Prayer Furor, supra note 16, at 43.

174. In part this was because of the longstanding view that nonsectarian prayers did not raise Establishment Clause concems, and in part it was because the country had just spent the last decade embracing its religious heritage. See GoRDON, stipra note 107, at 86-87 (discussing both and observing that " $[\mathrm{h}]$ owever predictable the holdings may seem decades later, they fell like a meteor into American society"); see also Kurland, stupra note 162, at 17 (noting "the wide-eyed surprise with which [Engel v.] Vitale was greeted by its detractors"). For an excellent discussion of the radical political and religious realignment that occurred when Protestant organizations that had been championing the separation of church and state in order to curb Catholic power leamed, much to their surprise, that the same arguments applied to them, see GordoN, stupra note 107, at 84-95.

175. See supra notes 18-20 and accompanying text. 
members spent their time denouncing the Supreme Court." 176 Members of Congress called Engel "the most tragic [decision] in the history of the United States," 177 an "outrageous edict which has numbed the conscience and shocked the highest sensibilities of the nation." 178 Engel was "the most serious blow that has ever been struck at the Constitution," one congressman claimed, a "bold, malicious, atheistic and sacrilegious twist."179 Two former PresidentsHoover and Eisenhower-immediately denounced the decision, with Hoover urging representatives to "at once submit an amendment to the Constitution" (which they did). ${ }^{180}$ Meanwhile, newspapers drowning in letters from angry readers erupted in editorial hate. ${ }^{181}$

The reasons varied. Many hated Engel for "secularizing" national life," single-handedly destroying America's identity as a Godly nation. " ${ }^{182}$ "Court Outlaws God," headlines blasted, ${ }^{183}$ while congressmen declared, "[T]he Supreme Court has held that God is unconstitutional," 184 and accused the Justices of a "deliberate design to subordinate the American people ... to a godless

176. Anthony Lewis, Op-Ed., Court Again Under Fire, N.Y. TimEs, July $1,1962, \S 4$, at 10 .

177. Anthony Lewis, Both Houses Get Bills to Lift Ban on School Prayer, N.Y. Times, June 27, 1962, at 1 (internal quotation marks omitted) (quoting Representative Frank J. Becker of New York).

178. Id. (intema] quotation marks omitted) (quoting Senator Herman E. Talmadge of Georgia).

179. 108 CONG. REC. 11,732 (1962) (quoting Representative L. Mendel Rivers of South Carolina).

180. See Opinion of the Week: Prayers in School, supra note 20 (quoting former Presidents Hoover and Eisenhower); "To Stand as a Guarantee," supra note 97, at 8 ("Two former U.S. Presidents took issue with the court."); see also infra notes 209, 274-87 and accompanying text (discussing proposed amendments to overturn Engel).

181. "To Stand as a Guarantee," supra note 97, at 7.

182. Alan F. Westin, Also on the Bench: 'Dominant Opinion,' N.Y. Times, Oct. 2], $1962, \$ 6$ (Magazine), at 30; see also The Court Decision-and the School Prayer Furor, supra note 16 , at 43 ("[N] $[\mathrm{d}$ ) religious feelings which are still bound up with their sense of national identity."); Opinion of the Week: Prayers in School, supra note 20 (quoting Cardinal Spellman as stating that "[t]he decision strikes at the very heart of the Godly tradition in which America's children have for so long been raised").

183. See WARREN, supra note 151, at 315-16 ("I vividly remember one bold newspaper headline saying, 'Court outlaws God,"'); see also LEVY, supra note 30, at 185 ("Newspaper headlines screamed that the Court had outlawed God from the public schools ...."). For a discussion of media coverage on Engel, see Part II.B below.

184. Lewis, supra note 176 (quoting Senator Sam J. Ervin of North Carolina); see also Lewis, supra note 177 (quoting Representative L. Mendel Rivers of South Carolina as stating that the Supreme Court had "officially stated its disbelief in God Almighty" (internal quotation mark omitted)); Editorial, Prayer and Hysteria, 195 NaTION 2, 2 (1962) (quoting a New York Daily Mirror article accusing the Supreme Court of "an attempt to expel God from American life" (internal quotation marks omitted)). 
state." 185 In ruling against God in the classroom, the Supreme Court had ruled against God, "bringing untold glee to the capitals of the godless communistic world." 186 Engel was the beginning of the end, "America's downfall."187 And the nation was not going down without a fight.

Others hated Engel for being patently undemocratic. "No longer does the majority rule in our nation," 188 one letter to the editor claimed, while an editorial lamented "a tyranny of the weak over the strong." ${ }^{189}$ Letters from citizens exclaimed, "The views of the majority need to be protected too!"190 In favoring "some fancied rights of a minority of citizens," 191 the Supreme Court had tumed the core precept of democratic governance on its head, subjecting majority will to minority rule.

Still others hated Engel for what it wasn't-a prayer worth getting worked up about. "[I]t is possible that the Court has given life to quiescent forces which will do more damage to our free institutions than the prayer ever did," ${ }^{192}$ one commentator wrote. Others, too, pointed to the innocuous nature of the Regents" Prayer, criticizing the Court for "grinding such small grist" and "absorb[ing] time and attention that should be devoted to the correction of evils that afflict far more people far more grievously than a few minutes lip-service

185. DierenField, supra note 14 , at 147 (intemal quotation mark omitted) (quoting Governor George Wallace of Alabama); see also 108 ConG. REC. 11,734 (1962) (quoting Congressman John Williams of Mississippi as stating that Engel was "a deliberate and carefully planned conspiracy to substitute materialism for spiritual values, and thus to communize America").

186. Editorial, supra notc 184, at 2 (quoting Representative John Bell Williams of Mississippi); see also Lewis, supra note 176 (quoting Representative L. Mendel Rivers of South Carolina as stating, "I know of nothing in my lifetime ... that could give more aid and comfort to Moscow" (internal quotation marks omitted)).

187. DifRENFIELD, supra note 14, at I (paraphrasing a statement by David Barton, a Texas Republican).

188. Letter to the Editor, COM. APPEAL (Memphis) (n.d.) (Hugo LaFayette Black Papers, Box 361).

189. See Gerald W. Johnson, Anise and Cummin, NEw Republic, July 9, 1962, at 8, 8; see also $A$ Loss to Make Up for, TIME, June 28, 1963, at 13,14 (quoting Billy Graham as stating, "I don't believe that a small minority should rule the majority of the people").

190. Letter from Dorothy Sowers to Justice Hugo L. Black (Mar. 1, 1963) (Hugo LaFayette Black Papers, Box 356) (emphasis omitted); see also Letter from Conelia 0. Edington to Justice Hugo L. Black (n.d.) (Hugo LaFayette Black Papers, Box 354) ("Is it the opinion of the court that minority groups should rule the majority, if so please tell me why this should be so?'); Letter from Anna Thurman Finch to Chief Justice Earl Warren (Mar. 2, 1963) (Hugo LaFayette Black Papers, Box 356) ("The real issue is simple and fundamental. Which shall prevail in the land-the wishes of the majority or the desire of a minority?").

191. 108 CONG. Rec. 12,227 (1962) (quoting Representative William Raleigh Hull, Jr., of Missouri).

192. Engel v Vitale, supra note 93 , at 5 ; see also Editorial, supra note 22 ("In part the shock may be explained by the innocuous nature of the prayer."). 
given to anything." 193 Maybe the Court was right about a state-drafted prayer, critics conceded, but the stakes were so small that it was "a stupid decision, a doctrinaire decision"194 - the "Ultimate in Asininity." 195

And still others hated Engel just for the occasion it presented to hate, for all that had come before it. Engel was the decision that Southerners in particular loved to hate, ${ }^{196}$ a "heaven-sent opportunity" to defend God Almighty while simultaneously attacking the Supreme Court. ${ }^{197}$ "They put the Negroes in the schools, and now they've driven God out," went one oft-quoted refrain. ${ }^{198}$ And aside from the fact that "Negroes" weren't actually in those schools yet, ${ }^{199}$ the statement summed up the South's position perfectly. ${ }^{200}$

193. Johnson, supra note 189, at 8; see also Pollak, supra note 98 , at 63 (faulting the Supreme Court for not "sav[ing] its scarce ammunition for a prayer that soared," spending it instead on New York's "clay-footed pigeon").

194. Alexander Burnham, Court's Decision Stirs Conflicts, N.Y. TimES, June 27, 1962, at 1 (internal quotation mark omitted) (reproducing a forthcoming editorial in the Pilot, the oldest Catholic paper in the United States).

195. An Ulitimate in Asininity, ENQUIRER (Cincinnati), June 28, 1962, at 6.

196. Interestingly, a 1964 empirical study explored a number of variables thought to influence attitudes regarding the Supreme Court's school prayer and Bible reading decisions, including church attendance, religious affiliation, age, sex, education level, urban/rural community, and geographic region in the United States. It concluded, "The most significant result of the multiple regression analysis is the confirmation it gives to the influence of region, or more particularly to distinctiveness of the South." Way, supra note 90, at 193-203. For an explanation of Southern exceptionalism on the issue of school prayer and how that has translated to persistent noncompliance with the Court's edicts on religious observances in school, see note 223 and accompanying text below.

197. Dierenfield, supra note 18, at 219.

198. Uproar over School Proyer-and the Aftermath, U.S. NEWS \& WORLD REP., July 9, 1962, at 42, 44 (intermal quotation marks omitted) (quoting Representative George W. Andrews of Alabama); see Editorial, supra note 184, at 2 (paraphrasing same); see also Lewis, supra note 176 (quoting Senator Sam J. Ervin of North Carolina as stating, "I should like to ask whether we would be far wrong in saying that in this decision the Supreme Court bas held that God is unconstitutional and for that reason the public schools must be segregated against Him?" (internal quotation marks omitted)).

199. See SuPreme COURT IN CONFERENCE, supra note 16, at 671 ("In 1964, ten years after Brown, only 1.2 percent of southern black children went to school with white children." (italics omitted)).

200. See Kenneth Crawford, The Prayer Debate, NewsweEk, July 16, 1962, at 28, 28 ("Some senators and representatives from the Deep South, who are still gunning for the Court because of its school-desegregation ruling, found the school-prayer decision too good an opportunity to resist."); Lewis, supra note 177 ("Southern members of Congress were among the most prominent critics. Some punctuated their denunciations with references to the racial segregation of schools."); Lewis, supra note 176 ("There were, first, those who were delighted to find any excuse to assault the Supreme Court. This was the particular reaction of Southemers, who did their best to suggest that the prayer nuling only showed how equally wrong the court had been to outlaw segregation in public schools."). 
That said, it wasn't just the Supreme Court's race-relations rulings that drove the furor over Engel. It was obscenity. ${ }^{201}$ It was Red Monday. ${ }^{202}$ It was reapportionment. ${ }^{203}$ It was search and seizure. ${ }^{204}$ The hysteria that followed Engel was a "caldron of criticism," 205 and as one commentator put the point, "[t]he criticism became clamor" and "[t]he clamor became frenzy." 206 Engel gave rise to a virtual feeding frenzy on the Supreme Court, a "national emotional binge" 207 of fury and hate.

With reaction to Engel so strong, action was sure to follow. Legislators claimed something had to be done "to calm the power grab of these powerdrunken men" ${ }^{208}$ and proposed a number of Court-curbing measures. Dominant in the discussion were proposals to amend the Constitution to overturn Engel. More than fifty such proposals were submitted within the first three days of the decision, and by the time congressional hearings were held in 1964, nearly 150 proposed constitutional amendments had been submitted. ${ }^{209}$ Legislators also

201. See Roth v. United States, 354 U.S. 476, 487 (1957) (narrowing the definition of obscenity while recognizing constitutional protection for nonobscene expression of sexual ideas); DIERENFIELD, supra note 14, at 151 (quoting one critic as saying, "The Court blesses these rags peddling their photographs of nude male models, but makes a prayer to God a violation of the Constitution!" (internal quotation marks omitted)); Uproar over School Prayer-and the Aftermath, stupra note 198, at 44 (quoting Representative August E. Johansen of Michigan as saying, "The upshot [of the Court's decisions] seems to be: Obscenity, yes; prayer, no" (alteration in original) (internal quotation marks omitted)).

202. Known as Red Monday, the Supreme Court issued four rulings on June 17, 1957, that struck down various anti-Communist measures. See Service v. Dulles, 354 U.S. 363, $365.68,382$ (1957) (invalidating the discharge of a foreign service officer in violation of State Department regulations); Yates v. United States, 354 U.S. 298, 318 (1957) (interpreting the Smith Act as not probibiting speech advocating the overthrow of the government in the abstract); Sweezy v. New Hampshire, 354 U.S. 234, 249-50 (1957) (recognizing a claim to academic freedom by a socialist college professor); Watkins v. United States, 354 U.S. $178,215-16$ (1957) (recognizing limits of congressional investigatory power); see also Westin, supra note 182, at 30 (quoting one critic as saying, "[I]t pays to be a Negro or a Communist if you want justice from the Warren Court").

203. See Baker v. Carr, 369 U.S. 186, 198-99 (1962) (holding legislative apportionment to be a justiciable issue). rule).

204. See Mapp v. Ohio, 367 U.S. 643,655 (1961) (constitutionalizing the exclusionary

205. Richard M. Johnson, The Dynamics of Compliance: Supreme Court DECISION-MAKING FROM A NEW PERSPECTIVE 82 (1967) (intemal quotation marks omitted).

206. CRAY, supra note 141 , at 389.

207. Excerpts from Editorials on School Prayer Decision, N.Y. TIMES, June 29, 1962, at 11 (quoting an editorial from the Salt Lake Tribune). The editorial warned, "It will be unfortunate if a national emotional binge is set off. Imesponsible and demagogic criticism by some members of Congress will not encourage needed thoughtful study of the decision and its real effects." $I d$.

208. SOLOMON, supra note 31, at 261 (internal quotation marks omitted) (quoting Representative Thomas Abernathy of Mississippi).

209. See Geoffrey R. Stone, In Opposition to the School Prayer Amendment, 50 U. CHI. L. Rev. 823, 826 (1983); see also Arthur E. Sutherland, Jr., Establishment According to En- 
called for the Justices' impeachment, ${ }^{210}$ for jurisdiction-stripping legislation, ${ }^{211}$ for the words "In God We Trust" to be inscribed above the Supreme Court's bench, ${ }^{212}$ and for federal funds to be appropriated to buy a Bible for each of the Justices. ${ }^{213}$ None of the proposed measures passed, but there could be no doubt as to where Congress stood. The Justices that year reportedly received a smaller annual raise than anyone else on the federal bench, ${ }^{214}$ and the House of Representatives voted (unanimously, no less) to place the words "In God We Trust" above the Speaker of the House's rostrum. ${ }^{215}$ It remains there today.

Outside Congress, people took action too. Protestors picketed the White House with signs that read, "Remove Warren, Restore God," and the John Birch Society added the words "Save Prayer" to its "Impeach Warren" billboards. ${ }^{216}$ Every governor in the nation, save one, endorsed a resolution condemning Engel and supporting a constitutional amendment to overturn it. 217

gel, 76 HARV. L. REV. 25, 50-51 (1962) (noting "fifly-odd proposals" immediately following Engel, most "directed to the precise Engel situation"); Kenneth Crawford, Politics and Prayer, NEWSWEEK, May 25, 1964, at 36, 36 (noting that "[n]o less than 147 bills" proposing to overtum Engel were introduced in the House).

210. See LaUBACH, supra note 38, at 2 (quoting Representative Alvin O'Konski of Wisconsin as saying, "We ought to impeach these men in robes who put themselves up above God" (internal quotation mark omitted)).

211. 108 CONG. REC. 11,732 (1962) (quoting Representative L. Mendel Rivers of South Carolina as arguing that unless other measures were taken, it was time "to drastically restrict and limit the appellate jurisdiction of this court which flaunts its authority in our very faces and it flaunts its authority because we have permitted them to run rampant over us").

212. See Lynda Beck Fenwick, Should the Children Pray?: A Historical, Judicial, and Polttical Examination of Public School Prayer 130 (1989); see also JaCK HARRISON POLLACK, EARL WARREN: THE Judge WHO CHANGED AMERICA 262 (1979) (noting that Chief Justice Warren wrote a letter that helped bury the bill).

213. See 108 CoNG. REC. 14,360-61 (1962) (quoting Representative James A. Haley of Florida as proposing to fund the purchase of a Bible "for the personal usc of each justice"). The proposal was rejected by a vote of 66 to 47 . LOUIS FISHFR, REL.IGIOUS LIBERTY IN AMERICA: POLITICAL SAFEguards 127 (2002).

214. See POLLACK, supra note 212 , at 262 ("In retaliation, the following March, House members denied Justices a $\$ 3,000$ annual pay raise on their $\$ 39,500$ salaries, even though they then voted \$7,500 increases for themselves, Cabinet officers and all lesser Federal judges.").

215. See LaUBACH, supra note 38, at 3; see also 108 CoNG. REC. 21,102 (1962) (quoting Representative William Randall of Missouri as justifying the move as "in a not so subtle way our answer to the recent decision of the U.S. Supreme Court order banning the regents prayer from the New York State schools").

216. See DIERENFIELD, stpra note 14, at 151-52; Dierenfield, supra note 18, at 219.

217. See Governors Seek Prayer Measure, N.Y. Times, July 4, 1962, at 1 (reporting on the nearly unanimous Governors Conference resolution, with only Governor Rockefeller of New York abstaining "because he thought the decision should be thoroughly studied before any action was taken"). 
And thirty-two state legislatures, just two short of the required two-thirds, called for a constitutional convention. ${ }^{218}$

Vows of open defiance were common. ${ }^{219}$ "We will not pay any attention to the Supreme Court ruling," ${ }^{220}$ one Southern superintendent stated, with another asserting that religious observances in school should continue "regardless of what the Supreme Court says." 221 Governors urged schools to "keep right on praying." 222 And in the South, that is exactly what most of them did. ${ }^{223}$

218. See SUPREME COURT IN CONFERENCE, supra note 16 , at 425 (italics omitted).

219. See The Court Decision-and the School Prayer Furor, supra note 16, at 45 ("Twenty-four states expressly permit or require prayers in schools, and in many of these areas, the judgment provoked open threats of defiance."); Nation Chooses Sides' in Fight over Proyer, supra note 17, at 64 ("[Fifteen] States have refused to give up devotional services in their public schools.").

220. The Court Decision-and the School Prayer Furor, stupra note 16, at 45 (internal quotation marks omitted) (quoting the Deputy Superintendent of Atlanta Public Schools); see also School Prayers: What's Scheduled This Autumn, U.S. News \& WorLo ReP., Aug. 19,1963 , at 11, 11 (listing statements of defiance from various states).

221. Burnham, supra note 194 (internal quotation marks omitted) (quoting the Alabama Superintendent of Education); see also William M. Beaney \& Edward N. Beiser, Prayer and Politics: The Impact of Engel and Schempp on the Political Process, 13 J. PUB. L. 475, 487 (1964) (quoting the Rhode Island State Commissioner of Education as stating that he did "not now or in the future intend to prostitute the office of Commissioner of Education of Rhode Island to further the cause of the irreligious, the atheistic, the unreligious, or the agnostic" (internal quotation marks omitted)). One school board president stated that the board had "no intention of abolishing prayer. If we are compelled to ban it, then we'll devise another prayer. A school without prayers is not a school." Theodore Powell, The School Prayer Battle, SATURDAY REV., Apr. 20, 1963, at 62, 63 (internal quotation mark omitted).

222. See DeLFATTORE, supra note 36, at 104 (quoting Governor George Wallace of Alabama). "I want the Supreme Court to know we are not going to conform to any such decision," Governor Wallace said. "I want the State Board of Education to tell the whole world we are not going to abide by it." Beaney \& Beiser, supra note 221 , at 486 (internal quotation mark omitted); see also Beaney \& Beiser, supra note 221, at 487 (quoting Governor Ross Bamett of Mississippi as saying that he was "going to tell every teacher in Mississippi to conduct prayers and Bible reading despite what the Supreme Court says" (internal quotation marks omitted)); Another Kind of Defiance, TIME, Aug. 16, 1963, at 16, 16 (quoting Governor Terry Sanford of North Carolina as saying, "We will go on having Bible readings and prayers in the schools of this state just as we always have" (internal quotation marks omitted)).

223. See Kenneth M. Dolbeare \& Phillip E. Hammond, The School Prayer Decisions: From Court Policy to Local Practice $33 \&$ tbl.8 (1971) (finding that $93 \%$ of school districts in the East complied with Engel, but only $21 \%$ of school districts in the South did so); see also SOLOMON, supra note 31 , at 310 (discussing a study showing that after Engel, $11 \%$ of schools in the East still conducted prayer, $5 \%$ of schools in the West still conducted prayer, but $64 \%$ of schools in the South still conducted school prayer). Frank Sorauf writes,

Explanations for the Southern noncompliance [with Engel and Schempp] are not hard to adduce - the conservative Protestant homogeneity, the general traditionalism of values, the rcinforcement of noncompliance in other areas of constinational decision, indeed the whole complicated web of the Southern culture that relates religion to other social values and institutions. 
In short, Steven Engel remembered it right in saying, "When we won the case ... all hell broke loose." 224 The Supreme Court thought it was protecting the people from an overzealous, prayer-pushing state. But that point was lost on the American people, who wanted protection from the Supreme Court instead. $^{225}$ There was a disconnect between what the Court said and what the people heard, and a disconnect between what happened before Engel and what happened after it. The question I explore next is why.

\section{B. The Role of Media and Misunderstanding}

Anyone who spends time with the historical record cannot help but notice that the public discourse surrounding Engel was not about what the Supreme Court actually held. The Justices themselves were partly to blame for that discourse. The rest of the responsibility lay with the media.

Turning first to the Justices, two wrote minority opinions in Engel, and both turn out to be important in understanding the nation's reaction to the case. As previously mentioned, Justice Stewart wrote a lone dissent in Engel. ${ }^{226}$ Not yet mentioned is the fact that Justice Douglas wrote a lone concurrence. ${ }^{227}$

SORAUF, supra note 105 , at 299 . He goes on to explain that "[e]nforcement by court order would have to be literally on a school-district-by-school-district basis, assuming the availability of plaintiffs willing to come forward against the pressure of the community." Id. at 300 .

Herein may lie a clue to the riddle of why the East readily complied with Engel and Schempp while the South did not, even though religious observances in both areas were equally entrenched. See id. at 297 tbl.12-5 (showing that in $1960,68 \%$ of public schools in the East and $77 \%$ of public schools in the South reported Bible reading, whereas in 1966 , only $4 \%$ of public schools in the East reported continued Bible reading compared with $50 \%$ in the South). In the East, there may have been enough religious diversity to pose a realistic threat of an enforcement action, whereas in the South, religious homogeneity and other factors contributing to community pressure may have been so strong that an enforcement action was unlikely. This surmise would also suggest that it is more than mere coincidence that cases like Engel and Schempp came from the East rather than the South. For an excellent empirical study of factors contributing to such community pressure, see generally Kevin T. McGuire, Public Schools, Religious Establishments, and the U.S. Supreme Court: An Examination of Policy Compliance, 37 AM. POL. RES. 50 (2009) (finding rural communities, less educated communities, and communities with higher concentrations of conservative Christians, all characteristics that dovetail with the South, to be statistically significant factors of noncompliance witb the Supreme Court's school prayer decisions).

224. DiERENFIELD, supra note 14 , at 138 (internal quotation marks omitted) (quoting Steven Engel).

225. See Postcard from Mary F. Dickinson to Justice Hugo L. Black (June 18, 1963) (Hugo LaFayette Black Papers, Box 355) ("Our eamest prayer is: 'God save America from the Supreme Court." ); Note from Peggy Ann Louis to Justice Hugo L. Black (n.d.) (Hugo LaFayette Black Papers, Box 355) ("God save us from the Supreme Court!").

226. Engel v. Vitale, 370 U.S. 42 1, 444-50 (1962) (Stewart, J., dissenting); see also sttpra note 129 and accompanying text (identifying Justice Stewart as the lone dissenter in $E n$ gel).

227. 370 U.S. at $437-44$ (Douglas, J., concurring). 
Both Justice Douglas and Justice Stewart argued that the prayer in Engel was indistinguishable from the myriad of other acknowledgments of God by the state; the only difference between the two was which way the argument cut. Justice Douglas claimed that any commingling of church and state was constitutionally impermissible. ${ }^{228}$ Thus, he agreed with the majority's ruling on school prayer and pointed to other practices the Supreme Court could, and should, strike down as well. ${ }^{229}$ Justice Stewart took the opposite stance, arguing that school prayer was just as constitutional as everything else. "I cannot see how an 'official religion' is established by letting those who want to say a prayer say it," he wrote, pointing to "countless practices" that recognized religion and were sponsored by the state. 230

The majority in Engel answered both Justices' claims, explicitly rejecting the premise upon which they were based-that school prayer and other references to God in government were indistinguishable. In characteristically confident style, the Engel opinion stated:

There is of course nothing in the decision reached here that is inconsistent with the fact that school children and others are officially encouraged to express love for our country by reciting historical documents such as the Declaration of Independence which contain references to the Deity.... Such patriotic or ceremonial occasions bear no true resemblance to the unquestioned religious exercise that the State of New York has sponsored in this instance. ${ }^{2}$

The line drawing was clear, but the statement was poorly placed. The majority had relegated the passage to a footnote that most everyone overlooked, including critics and the popular press. ${ }^{232}$ The New York Times, for example, reprinted the entire Engel opinion, along with parts of the concurrence and dissent, but neglected to include the footnote that addressed those Justices' claims. ${ }^{233}$ Critics decried Engel's broad, sweeping language, and chided the Supreme Court

228. See id. at 437 ("I think it is an unconstitutional undertaking whatever form it takes.").

229. See id. at $437 \mathrm{n} .1$.

230. Id. at 445-46 (Stewart, J., dissenting).

231. Id. at $435 \mathrm{n} .21$ (majority opinion).

232. See Raymond J. Celada, Library of Cong. Legislative Reference Serv., The Supreme Court Opinion in the School Prayer Case (Engel v, VITale): The Decision, THE REACTION, THE PROS AND CONS 12 (1963) ("The Court attempted to indicate the narrow limits of its holding in a significant but generally overlooked footnote to the opinion ...."); FENWICK, supra note 212 , at 133 ("Unfortunately, most people skip over footnotes, and many of the published reports of the decision omitted any reference to this footnote. Intended to allay such fears as those expressed by religious leaders ..., the footnote was instead ignored."); "To Stand as a Guarantee," supra note 97 , at 9 ("Black's footnote was virtually ignored in the public reporting of the decision....").

233. See Text of Opinions in Supreme Couft Case Holding School Prayer Unconstitutional, N.Y. TIMES, June 26, 1962, at 16. 
for its "failure to emphasize the limitations of the decision." 234 In fact, those limits were there. They just weren't where anyone would have thought to look.

In different ways, both the concurring and dissenting opinions in Engel played a prominent role in the fury that followed the case. Justice Stewart's dissent fueled hyperbolic claims that in striking down school prayer, the Supreme Court had told schoolchildren they could not pray even if they wanted to. "[T]o deny the wish of these school children to join in reciting this prayer is to deny them the opportunity of sharing in the spiritual heritage of our Nation," he wrote. ${ }^{235}$ Justice Stewart viewed Engel in free exercise terms, and in the public discourse, his was the view that stuck. ${ }^{236}$

Meanwhile, Justice Douglas's concurrence lent legitimacy to claims that the Court would soon be taking aim at other aspects of God in public life. Time and again, critics pointed to Engel's concurrence for the implications of the case. ${ }^{237}$ Indeed, on numerous occasions they quoted Engel's concurrence as though it was the holding in the case, leading many people to think it actually was. ${ }^{238}$ This was especially incendiary because unlike Justice Stewart, who had

234. Irving R. Kaufman, The Supreme Court and lis Critics, AtLantic, Dec. 1963, at 47, 50; see also Arthur Krock, Op-Ed., The Prayer Ruling, N.Y. TIMES, July 1, 1962, \$ 4, at 9 (describing Engel as "the latest in a series of high judicial rulings on the issue of churchstate separation that continue to supply no guide to the next one"); Lewis, stpra note 135 (writing that the "sweeping language" of the opinion made it "impossible to draw . . any conelusion on what the Supreme Court will or will not allow"); Anthony Lewis, Op-Ed., School-Prayer Issue in High Coum Again, N.Y. TimEs, Oct. 14, 1962, \$ 4, at 5 ("Th[e] limits [of the Court's decision] have been difficult to set with any degree of confidence because Justice Hugo L. Black's opinion for the court was so broadly and vaguely phrased. The lack of boundaries in turn has doubtless served to heighten public agitation.").

235. See 370 U.S. at 445 (Stewart, J., dissenting).

236. See Powell, supra note 221, at 62-63 ("Much opposition arose out of the mistaken impression that the decision was based on the 'frec exercisc' clausc."); "To Stand as a Guarantee," supra note 97, at 8 ("The Supreme Court last week based its ruling solely on the 'establishment' clause, but many Americans got an impression that the court impaired the free exercise of religion. This impression was fortified by Justice Stewart's dissent ....").

237. See Beaney \& Beiser, supra note 221, at 479; see also The Court Decision-and the School Praver Furor, supra note 16, at 44 ("It was the concurring opinion, by Justice William O. Douglas, however, which gave the aroused critics of the decision their greatest fears."); Editorial, In the Name of Freedom, WALL ST. J., June 27, 1962, at 14 ("If the majority opinion prevails, however, it must logically require the excision of all those countless other official references to God-such as in the Declaration of Independence, the Pledge of Allegiance, [and] the Star-Spangled Banner ... . Justice Douglas, concurring with the majority, seems to say it does and should apply to these and all the other officjal instances.").

238. See "To Stand as a Cuarantee," supra note 97, at 8 ("Adding greatly to the confusion was Justice Douglas' concurring opinion - which was mistakenly understood by many as having some force of law."); see also Beaney \& Beiser, supra note 221, at 485 ("[M]uch of the bitter first commentary was uninformed, and frequently was based on sentences ripped out of the context of the Court's opinion, or to be found only in the concurring opinion of Mr. Justice Douglas."); Chester A. Newland, Press Coverage of the United States Supreme Court, 17 W. PoL. Q. 15, 25 (1964) ("Basis for the most extreme and unplausible public crit- 
lamented Engel's implications, Justice Douglas embraced them as right. ${ }^{239}$ Writing in the 1962 Supreme Court Review, Philip Kurland described Engel as a picture of the majority Justices "walking on eggs and of the two minority Justices stamping after them." ${ }^{240}$ It was an apt analogy, particularly in light of the mess in their wake.

In fairness, neither of the minority opinions in Engel could have been fully responsible for the hysteria that followed the decision, because the Supreme Court came under attack well before anyone had time to read them. ${ }^{241}$ Engel's concurrence and dissent may have bolstered critics' claims, but they are just a part of understanding the misunderstanding that marked the case. For the rest of the story, one must leave the world of law altogether and enter the world of journalism.

Within legal academia, Engel is a case study in Supreme Court decisionmaking (and on the doctrinal side, First Amendment law, of course). But within journalism scholarship, Engel is a case study for an entirely different proposition-how the media's coverage of Court decisions can skew public opinion. ${ }^{242}$ As is so often the case, the insights of an interdisciplinary perspective enrich our understanding considerably.

From a joutnalistic viewpoint, the story begins with the Supreme Court's announcement of Engel and the media race to report the ruling. ${ }^{243}$ The first wire service reports on Engel went out within five minutes of the decision's announcement, feeding what would become the lead story in all news outlets by the end of the day and front-page news the following morning. ${ }^{244}$ Unfortu-

icisms of the majority opinion are to be found in the dissent by Mr. Justice Stewart; and Justice Douglas' unrestrained remarks in a concurrence provide equally ample fuel for critics.").

239. See Engel v Vitale, supra note 93, at 4 ("Mr. Justice Douglas concurring and $\mathrm{Mr}$ Justice Stewart dissenting both thought-the one approvingly, the other with regret --that all sorts of invocations of the Deity associated with our public life are or will soon become unconstitutional."); stpra notes 226-28 and accompanying text (discussing the opinions of Justices Douglas and Stewart).

240. Kurland, supra note 162, at 13.

241. See Thomas M. Mengler, Public Relations in the Supreme Court: Justice Tom Clark's Opinion in the School Prayer Case, 6 CONST. COMMENT. 331,337 (1989).

242. See, eg., David L. Grey, The Supreme Court and the News Medta (1968); Newland, supra note 238; William A. Hachten, Journalism and the Prayer Decision, COUUm. JOURNAlism Rev., Fall 1962, at 4, 4.

243. Engel was announced on June 25, 1962, along with fifteen other decisions. Hachten, supra note 242 , at 4 . It was the only one to command immediate media attention. See id. For a glimpse of history repeating itself, see Katherine Fung \& Jack Mirkinson, $S_{u-}$ preme Court Health Care Ruling: CNN, Fox News Wrong on Individual Mandate, HufFINGTON POST (June 28, 2012, 10:29 AM EDT), http://www huffingtonpost.com/2012 106/28/crn-supreme-court-health-care-individual-mandate_n_1633950html (discussing the modia's mishandling of the Supreme Court's health care ruling in 2012).

244. See GREY, supra note 242, at 87-88 ("Justice Black started reading Engel at about 11:50 A.M. on June 25, $1962 \ldots$ In both Engel and Schempp, the AP and UPI were out with bulletins within five minutes of the start of announcing the cases in the courtroom."); Hachtcn, supra note 242, at 4 ("Wire-service reporters led their stories with [Engel], radio 
nately, none of the reports stressed the limited nature of the Court's ruling; indeed, the AP bulletin failed to note the state-sponsored nature of the prayer at all. $^{245}$ Thus, from the start, media reports gave the impression that the Court had forbidden prayer of any type--individual or state sponsored-in public schools. ${ }^{246}$ Newspapers sensationalized the ruling with headlines such as "No Praying in Schools, Court Rules" and "Supreme Court Outlaws Prayers in Public Schools" that exaggerated the holding of the case and provided terse, oversimplified accounts of the decision that were at best incomplete. ${ }^{247}$ Radio and TV quickly followed suit. ${ }^{248}$

Meanwhile, public officials likewise reacted to the AP and other wire service reports, quickly going on record to criticize Engel and take a stand in favor of God, prayer, and the American way. ${ }^{249}$ The commentary was uninformed

and television and afternoon newspapers used it prominently, and by the following morning it had become the leading story in most newspapers."); see also Mengler, supra note 241, at 336 ("The response to the Engel decision was literally instantaneous and, consequently, uninformed.").

245. See GREY, supra note 242 , at 88.

246. See JoHNSON, supra note 205 , at 75 ("In no instance d[id] a headline ... indicate that the banned prayer was one composed by state officials and preseribed by a school board---both relevant considerations as far as the Court was concened."); Hachten, supra note 242, at 5 ("The majority of newspapers appear to have kept 'prayer' in the singular, but many failed to specify... its official character...."); A Loss to Make Up for, supra note 189 , at 13 ("Misled by headlines, many thought that the court had all but ordered an end to all ties between government and religion...."); see also Excerpts from Editorials on School Prayer Decision, supra note 207 (quoting the Evening Star as stating: "The real effect of the Court's ruling is to prohibit children who might wish to do so from teciting the prayer"). Because the only prayer in schools at this time was state-sponsored prayer, one can readily see how the media conflated the two.

247. Newland, supra note 238 , at 29 (discussing these and similar headlines, including "No Prayers in Schools, Supreme Court Orders" and "Possible End to Christian, Jewish Holy Day Activity in Public Schools as Court Bans N.Y. Prayer"); Hachten, supra note 242, at 5 (discussing similar headlines, including "Court Rules Out Prayers in Schools" and "High Court Bans School Prayer"); see, e.g., Joseph Hearst, Stpreme Court Bans School Prayers, ChI. Dally TRIB., June 26, 1962, at 1; School Prayer Ruled Out, L.A. Trmes, June 26, 1962, at 1; see also Leo Katcher, Earl Warren: A Political BIography 422 (1967) ("[T]he early newspaper treatment of the decision was incomplete, inaccurate, and intended to make headlines rather than to report the facts."); Mengler, supra note 241, at 337-38 ("The press caused perhaps greater damage through its incompetent interpretation of the decision and aggressive attempts to fan the flames. Headlines the morning after the decision obscured the narrowness of the Court's explicit holding....").

248. See JoHnSON, supra note 205, at 84-85 ("Thus the radio and TV newscasts, with their characteristic incisiveness and drive to report events 'as they happen,' conveyed an image of a much broader ruling than was actually handed down. In this rcgard their treatment was similar to the early news stories.").

249. See Mengler, supra note 241 , at 336 ("[C]ongressmen who spoke went on the record quickly and, sensing a political bonanza, almost uniformly criticized the decision."); Lewis, supra note 176 ("The grotesque distortion of suggesting that the court had held God unconstitutional was characteristic of many comments. The purpose was abuse, not rational 
and "not a little demagogic."250 But with proposed constitutional amendments flying, it was newsworthy, and papers quickly shifted from reporting on Engel to reporting on the reaction to the case. ${ }^{251}$ Here too the media fanned the flames, focusing almost exclusively on the comments of extremists and following up with interviews to solicit the strongest sound bite reporters could get. ${ }^{252}$ Surveying the scene, the New York Herald Tribune lamented "the sight of so many otherwise responsible newspapers getting completely swept off their feet by the tide of emotionalism." 253 Scholars reviewing the news reports agreed, finding "serious distortions" in the media's reporting of the case ${ }^{254}$ and concluding that there was "little question" that the way the news was handled contributed to the reaction against Engel. ${ }^{255}$

All this points to a conclusion that several news magazines noted at the time: Engel was hated "not so much for what it said as for what people thought it said."256 Time magazine was one of the first to make the point, stating:

discussion of the court's reasoning. And so these critics tended to denounce the motives of the justices, terming them pro-Communist, atheistic, conspiratorial.").

250. Crawford, supra note 200, at 28; see also FENWICK, supra note 212, at 130 ("Yet many of the people voicing the greatest outrage spoke out against [Engel] without having read the opinion."); JoHvSON, supra note 205, at 91 ("The Educational Executives' Overview was particularly outraged about the fact that so many 'pontificated so freely' about the decision without bothering to see what the Court had said.").

251. See JOHNSON, supra note 205 , at $72-73,74$ tbl.2 (noting that "[s]ubsequent articles appearing on the news pages ... were uniformly concerned with public reaction to the decision," and listing headlines, including "Prayer Decision Stirs Anger," "Prayer Ruling Stirs Caldron of Criticism," "Lawmakers Seethe over Prayer Ban," "Local Religious Leaders Deplore Prayer Ban," and "Court Ruled Against God: Goldwater," among others); Newland, supra note 238, at 27 ("Starting with day-two stories and throughout the remainder of the week, however, reports drawn from wire services generally departed far ftom the Court's action and stressed reaction instead.").

252. See Hachten, supra note 242 , at 8 ("[T] he wire services obtained comment largely from the angriest members of Congress."); see also Mengler, supra note 241, at 338 ("Arguably worse than its misinterpretation was the press' solicitation of uninformed criticism. Starting immediately after the decision's announcement and continuing through the rest of the week, the press departed from wire service interpretations of the decision and actively sought good quotes."); Newland, supra note 238, at 27-28 ("On the Prayer case, wire reports of national level reaction were numerous and often on extreme views, completely obscuring the Court's opinion in most newspapers... Solicited opinions of political and religious spokesmen and of uninformed people in general dominated the news.").

253. Rockefeller Keeps His Head, N.Y. Herald TriB., July 5, 1962, at 18.

254. Newland, supra note 238, at 29.

255. Hachten, supra note 242, at 7 ("There seems little question but that the mochanics of handling news contributed to the reaction."); see also GREY, strpra note 242 , at 92 ("[I]t is hard to assess press responsibility for the uproar caused by the earlier decision. But, again at minimum, it would seem that the press was one element in the Engel case."). For an explanation of why Engel's countermajoritarian narrative has persisted despite such evidence, see text accompanying notes $272-73$ and 400 below.

256. A Loss to Make Up for, stpra note 189, at 13; see also Does Schoolroom Prayer Require a New Amendment?, TIME, May 8, 1964, at 62, 62, 64 ("Much of the cry to "Get God Back in the Schools' reflects deep misunderstanding of what the court actually said."). 
Much of last week's controversy arose from confusion about what the Supreme Court ruled-and, perhaps more importantly, what it did not rule. All too typical was the reaction of an Atlanta clergyman who called the decision "the most terrible thing that's ever happened to us"- then admitted he did not really know what the decision said.

Letters to the Justices confirmed it, ${ }^{258}$ and surveys showed it in spades ${ }^{259}$ people viewed Engel just as newspapers had reported it, as banning any and all prayer in public schools. Indeed, in one study, a whopping $78.8 \%$ of participants thought Engel said "prayer in the public schools was to halt," while just $10.5 \%$ thought the ruling banned "state-prescribed prayer . . . but saw no impairment of prayer in general." ${ }^{260}$ Inadvertently proving the point, the study then went on to conclude (wrongly) that most people had gotten Engel right. ${ }^{261}$

The Justices felt they had been burned. Justice Black privately stated that Engel was "grossly misrepresented and misunderstood" and expressed hope

257. "To Stand as a Guarantee," supra note 97, at 8.

258. Some letters illustrated the confusion, See, e.g., Letter from Mary Kathryn Davis to Members of the Supreme Court (Mar. 1, 1963) (Earl Warren Papers, Box 366) (expressing distress "at the thought of not bcing able to say a simple prayer in the public school which I attend" and accusing the Justices of "trying to take away the privilege of being able to worship FREELY whenever and WHEREVER we wish"); Letter from Madeline Theresa McLain to Justice Hugo L. Black (n.d.) (Hugo LaFayette Black Papers, Box 355) ("Your decision to outlaw God from public life is very bad."); see also Letter to Justice Hugo L. Black (n.d.) (Hugo LaFayette Black Papers, Box 355) (sharing a poem, titled "Prayer on the Q.T." that opens with the line, "Now I sit me down to school / Where praying is against the nule"); Petition (n.d.) (Hugo LaFayette Black Papers, Box 355) (proposing a constitutional amendment "to guarantce that nothing in this constitution shall be construed to prohibit the voluntary expressions of belief in the existence and providence of God, or the voluntary saying of prayers addresscd to God").

Other letters recognized the confusion. See, eg., Letter from Fred Larkins to Justice Hugo L. Black (July 1 1, 1962) (Hugo LaFayette Black Papers, Box 354) ("I am really concerned because of the greatly distorted views taken by the press and many individuals of the Prayer decision. The truth is that regarding it as prohibiting prayer in schools makes a much better and more sensational news story than to merely refer to it as a prohibition of preparation and promulgation of prayers by public officials."); Letter from George Mills to Justice Hugo L. Black (nl.d.) (Hugo LaFayette Black Papers, Box 355) ("Also, the uproar over your decision on prayer in schools appears to me to indicate a serious lack of understanding ....").

259. A 1968 survey asked, "In general, what has the Supreme Court said about prayers in the public schools?" Illustrative responses included, "They are not supposed to say prayers or mention God in school"; "They"ve just cut it out completely"; "It banned them, I think"; "I don't recall what they said but they took the prayer out of the schools"; "They ruled it out"; "They made a ruling that there were to be none"; and "It ruled them out. I don't know for what reasons. . . [T] hat's what is wrong with our nation." Gregory Casey, Popular Perceptions of Supreme Court Rulings, 4 AM. POL. Q. 3, 9, 10 \& tbl.1 n.a (1976) (internal quotation marks omitted).

260. See id. at 10-11.

261. See id at 11. 
that in due time the truth about the ruling would come to light. ${ }^{262}$ Chief Justice Warren expressed similar views, stating in private correspondence that he hoped that as Engel became "more clearly understood the hysteria concerning the decision w[ould] subside." 263 Justice Brennan was slightly more pointed in his views, publicly stating that those who criticize a decision of the Supreme Court "should at least read the decision" to attempt to understand it first. ${ }^{264}$

And Justice Clark was more to the point yet. At an American Bar Association meeting two months after Engel was decided, Justice Clark broke from judicial custom of not commenting on the merits of a case to explain the decision to the public. ${ }^{265}$ "Here was a state-written prayer circulated to state-employed teachers with instructions to have their pupils recite it in unison at the beginning of each school day," he stated, faulting the press for writing stories that were inaccurate and incomplete. ${ }^{266}$ Afterward, Justice Clark observed that

[a]s soon as people learned that this was all the court decided-not that there could be no official recognition of a Divine Being or recognition on silver or currency of "In God We Trust", or public acknowledgement that we are a religious nation - they understood the basis on which the court acted. ${ }^{267}$

Ironically, his comments received little attention in the popular press. ${ }^{268}$

As to whether such attempts to clarify Engel made much difference, the evidence is mixed. One researcher concluded, "As the volume of informed com-

262. Letter from B.W. Simmons to J.A. Fortner (Jan. 17, 1963) (Hugo LaFayettc Black Papers, Box 354) ("I talked with Justice Black .... [He] stated that the textual content of the decision was grossly misrepresented and misunderstood and that he hoped in time the real efficacy of the opinion and its objectives would be disseminated to the public."); see also Letter from Justice Hugo L. Black to Tom Murphy, Minister to Students, Auburn Univ. (July 3, 1962) (Hugo LaFayette Black Papers, Box 358) ("Enclosed is the copy of all the opinions of the Court in the case involving the New York Regents' official public school prayer. 1 can readily understand how difficult it has been ... for you to know what the Court decided in this case from much of the newspaper publicity about it.").

263. Letter from Earl Warren to Thomas J. Cunningham, Vice-President \& Gen. Counsel, Univ. of Cal., Berkeley (Oct. 15, 1962) (Earl Warren Papers, Box 365).

264. High Court Found Imperiled by Foes, N.Y. TIMES, Aug. 30, 1963, at 13 (internal quotation mark omitted) (quoting Justice Brennan); see also id. ("He cited the decision banning ritual prayers in the public schools as an example of decisions that produced criticism by persons unfarmiliar with what the Court said.").

265. See Hachten, supra note 242 , at 4 ; see also SCHWARTZ, supra note 157 , at 442 (discussing Justice Clark's "almost unprecedented step of publicly defending" a Supreme Court decision). For Justice Black's view of the propriety of speaking to the press about Engel, see Letter from Justice Hugo L. Black to Paula Fraser (July 9, 1962) (Hugo LaFayette Black Papers, Box 358) ("Thanks for your interesting note of June 27th about our judgment and opirion in the New York Regents' official state prayer case. Your suggestion that I talk about the case on the radio or television is interesting, but I could [n]ot do this.").

266. Hachten, supra note 242 , at 4 (internal quotation mark omitted).

267. $I d$.

268. See Newland, supra note 238 , at 29. 
ment grew, the reaction [to Engel] continued to subside,"269 and letters to Justice Black confirmed that at least some who took heed to actually read the decision did in fact change their view. ${ }^{270}$ But at the end of the day, Engel remained a staunchly unpopular decision, with substantial majorities favoring school prayer (at least according to the results of most polls). ${ }^{271}$ Scholars blamed the media for not publishing follow-up stories to correct erroneous reports promptly, concluding that by the time the decision was clarified, initial misperceptions had "hardened into the perception of fact." 272 The public had made up its mind about Engel, and was not open to changing it. ${ }^{273}$

269. Hachten, supra note 242, at 7; see also Paul G. Kauper, Prayer, Public Schools and the Supreme Court, 61 Mich. L. REV. 1031, 1031-32 (1963) ("Moreover, much of the initial criticism was dissipated when the Court's full opinion was read and understood.").

270. See Letter from Justice Hugo L. Black to Roland Frye (July 17, 1962) (Hugo LaFayette Black Papers, Box 354) ("In recent days I have also had a number of communications from people whose views have changed since they became familiar with what the Court decided. The quality of thought expressed in these communications has demonstrated that the capacity for thinking has not been lost in this country."); Letter from Margaret Hopkins Worrell, Exec. Sec'y, Nat'l Shrine Comm'n, to Justice Hugo L. Black (Dec. 6, 1962) (Hugo LaFayette Black Papers, Box 354) (expressing changed view upon reading the decision); see also NEWMAN, supra note 158, at $\$ 23$ ("Many people wrote to say they changed their minds about the decision once they read it ....").

271. See 30 Years After the Supreme Court's School Prayer Decision, AM. ENTERPRISE, Mar./Apr. 1992, at 102, 102 (reporting tesults of a September 1964 Gallup poll it which $77 \%$ of those asked said they would "[f]avor a constitutional amendment to legalize prayers in public school"); id. at 104 (reporting results of a June 1988 Gallup poll in which $70 \%$ of those asked said they "[f]avor[ed] prayer in public schools").

Interestingly, although support for the concept of school prayer is strong, the polling results look much different when the question is concrete. Since the mid-1980s, support for "Christian prayer" in schools has hovered around 10\%, support for "general prayer" (like the prayer in Engel) has hovered around 20\%, and support for "silent prayer" has hovered around 50\%. See Alison Gash \& Angelo Gonzales, School Prayer, in PUBlic OpINION AND Constitutional Controversy 62, 68-70 (Nathaniel Persily et al. eds., 2008) (comparing results of polls asking about support for school prayer in general with polls starting in the mid-1980s asking about support for specific categories of prayer).

272. Solomon, supra note 31, at 263; see also FISHER, supra note 213, at 126 ('The public impression never recovered from these irresponsible readings."); GREY, supra note 242 , at 95 ("[A]bsent was any full-fledged drive by the wire services, especially, to spced their clarifications. ... [M]uch of the news coverage of the Engel decision failed to meet a demanding standard of adequacy."); Hachten, supra note 242, at 9 ("Yet there should be a point in the development of a story where speed gives way to reflection. For much of American journalism, this point came too late in the school-prayer case. And for one segment, it never came at all.").

273. See William C. Adams, American Public Opinion in the 1960s on Two ChurchState Issues, 17 J. CHURCH \& ST. 477, 479 (1975) ("A remarkable 97 percent of that large majority favoring school prayers said that their minds were made up. Furthermore, 90 percent of those opposing school prayers had no doubts about their stance. This degree of certainty may explain the striking similarity between the 1964 and the 1968 data on the school prayer issue."). 
That said, there is another indication of what an informed public might have thought about Engel, and it comes from an unlikely source: the congressional hearings to overtum it. By the time of those hearings in 1964, some 150 proposals to amend the Constitution had been submitted by 115 members of Congress. ${ }^{274}$ Observers thought an amendment stood a good chance of passing if it could make it out of the House Judiciary Committee, and a majority of the Judiciary Committee members reportedly supported it at the outset. ${ }^{275}$ Even so, a discharge petition to spring the amendment from committee and bring it straight to the House floor had $16^{7}$ votes at the start of the hearing process-just 51 short of the necessary $218 .^{276}$ At the time, pressure to pass some sort of constitutional amendment was considered "nearly irresistible." 277

But the hearings changed everything. Supporters of the amendment process had taken a simplistic view: "The people want prayers in schools; the Court took them away; we, on behalf of the people, must restore them."278 The hearings showed just how complex the issue actually was. What would the prayer look like? Proponents of an amendment yielded to the inclusion of the words "nondenominational" or "nonsectarian" in the proposed amendment's text, but then the question became what those words meant, and who would get to define them. ${ }^{279}$ The best supporters could do was propose that local school boards decide what was appropriate for each school, but that led to questions about what

274. See DELFATTORE, supra note 36, at 116 . The Senate Judiciary Committee held two days of hearings in July 1962, but because the Justices recognized jurisdiction in Schempp shortly thereafter, the amendment process was deemed premature and no action was taken. See Steven K. Green, Evangelicals and the Becker Amendment: A Lesson in Church-State Moderation, 33 J. CHuRCH \& ST, 541, 551-52 (1991). Even after Schempp was decided, the amendment process initially stalled because the Chair of the House Judiciary Committee was opposed to an amendment. See id, at 557.

275. See Beaney \& Beiser, supra note 221, at 497 (noting that in early 1964, opponents of the amendment thought that it "had an excellent chance of receiving the approval of a majority of the Judiciary Committee, that if reported out favorably it was likely to pass easily in the Housc, and that while the Senate might delay passage of the bill, it would eventually pass there as well"); id. at 502 (noting that at the beginning of the committee hearings, observers estimated that the amendment "would easily win a majority in the committee"); Nation Chooses Sides in Fight over Proyer, supra note 17, at 64 ("Sentiment in the House at this time appears to favor passage of an amendment if the Judiciary Committee can agree on language and get a resolution to the floor.").

276. See Nation Chooses Sides in Fight over Prayer, supra note 17, at 64.

277. LAUBACH, supra note 38, at 84; see also ALLEY, supra note 17, at 123 ("The mood was such that the Religions News Service offered the opinion, 'Congress will take action before fall to submit such an amendment to the states for ratification.'").

278. Beaney \& Beiser, supra note 221, at 501 .

279. LAUBACH, supra note 38, at 73; see also Beaney \& Beiser, supra note 221, at 500 ("Which version of the Bible would be used? Would the Koran qualify under the amendment? Who would decide which prayers to say? Could the 'Ave Maria' be employed? And again and again they returned to the basic theme: "thou shalt not touch the Bill of Rights."'). 
that would look like too. ${ }^{280}$ Would each school district have a dominant religion, with the expectation being that people would move to the religious area of their choice? Or were school districts expected to be able to accommodate numerous interests, if that was even possible? And what about the divisiveness, and litigation, that would inevitably ensue if the hard questions were punted to localities to work out on their own?

These questions and more filled three thick volumes of House Judiciary Committee records, encapsulating 2774 pages of testimony by 197 witnesses over the course of eighteen days. ${ }^{281}$ Observers noted that proponents of the amendment "frequently seemed annoyed by the complexities of issues framed by opponents." 282 Reporting on the hearings in 1964, Newsweek summed up the glitch: "Everybody admits the difficulty of writing a proper amendment or even an acceptable school prayer. Nothing is as simple as it once seemed." 283

As the hearings progressed, the tide turned on support for a constitutional amendment. Congressmen reported a change in the constituency mail they were receiving, noting that correspondence once running twenty-to-one in favor of an amendment was now running just as strongly the opposite way. ${ }^{284}$ Some who had been among the first to call for an amendment now opposed it, and others who had signed the amendment's discharge petition were prepared to take their names off should the total start to approach the number necessary to get to the House floor. ${ }^{285}$ The Wall Street Journal reported that calls to amend the Constitution had "trailed off to a whisper" and that only eight of the House Judiciary Committee's thirty-five members still supported an amendment. ${ }^{286}$ The proposal died quietly in committee. ${ }^{287}$

280. See LaUbaCH, supra note 38, at 73-74. Indeed, the Judiciary Committce's staff sudy report raised so many questions about the practicalities of school prayer that several members of the Committee strenuously objected to its release. See Beaney \& Beiser, supra note 221 , at 498 .

281. Beaney \& Beiser, supra note 221, at 499.

282. Id at 501; see also DeLFATTORE, supra note 36, at 120 ("Supporters of the amendment were infuriated by questions about how this process would work for the same reason that its opponents kept asking them: they shone a spotlight on contentious issucs that Becker would have preferred to finesse....").

283. Crawford, supra note 209, at 36.

284. See A Tide Reversed, TIME, June 19, 1964, at 60, 65.

285. See LaUbACH, supra note 38 , at 85 ("Congressman Leggett, one of the first sponsors of a prayer amendment, had changed his mind and was urging the committee to reject the Becker proposal."); Beaney \& Beiscr, supra note 221, at 502 ("It was apparent that the drive for a discharge petition had passed its erest; not only could it not gain the necessary 218 signatures, but members who had signed the petition were prepared to remove their names should the total approach 210 .").

286. Joseph W. Sullivan, Support Fades for Change in Constitution to Allow Bible Reading, Prayers in Schools, WALL ST. J., June 16, 1964, at 3.

287. See id. (" $[T]$ he prevailing disposition on the House committee is to bury the prayer issue as qujetly as possible. 'The only reason its obituary notice hasn't gone out already is that we still don't know how to write it without risking another furor,' confides one committee leader."), Interestingly, later attempts to restore school prayer by constitutional amend- 
But the postscript to the story is, for present purposes, almost the best part. In the process of responding to objections during the hearing process, the text of the proposed amendment was repeatedly edited, bringing it closer and closer to the Supreme Court's position in Engel. ${ }^{288}$ In the end, the amendment that died in committee became a plank in the 1964 Republican Party Platform, which declared support for

a Constitutional amendment permitting those individuals and groups who choose to do so to exercise their religion freely in public places, provided religious exercises are not prepared or prescribed by the state or political subdivision thereof and no person's participation therein is coerced, thus preserving the traditional separation of church and state. ${ }^{289}$

The messaging was better, but the substance was the same. What the Republicans wanted was no different from what the Supreme Court in Engel had actually held.

In short, it is anything but clear that Engel was a decision the public hated on the merits, or even disagreed with at all. Misunderstanding played a massive role in tanking the case. I turn next to the role that the religious establishment played in saving it.

\section{The Role of Religious (and Other) Elites}

Lest the discussion thus far give the wrong impression, the hostility that met Engel was bitter, loud, and overwhelming - but it was not unanimous. A number of voices came to the Supreme Court's defense, and they too played a critical role in the narrative of the case. Education elites--high-echelon education officials, the organizations they belonged to, and the professional publications they read-uniformly supported Engel. ${ }^{290}$

ment failed for the same reason: once congressmen had to grapple with what school prayer would actually look like on the ground, the drive for a constitutional amendment lost support. See infra note 388 and accompanying text (describing legislators' attempt to restore school prayer by constitutional amendment in the 1980 s).

288. The original text of the amendment read, "Nothing in this Constitution shall be deemed to prohibit the offering, reading from, or listening to prayers, or biblical scriptures, if participation therein is on a voluntary basis, in any govemmental or public school, institution, or place." School Prayers: Hearings on Proposed Amendments to the Constitution Relating to Prayers and Bible Reading in the Public Schools Before the H. Comm. on the Judiciary, 88th Cong. 236 (1964) [hereinafter Hearings]. But the language softened as the hearings progressed. See $i d$. at 2320 (considering language to set aside time for "silent prayer by any individual or group on a voluntary basis"); $i d$. at 2358 (considering language to protect a parent's right to have "children engage in voluntary religious exercise"); see also LALBACH, supra note 38 , at 151 ("But the more the texts were modified to meet the acknowledged objections, the more they resembled the Supreme Court's own position in the Engel and Schempp cases.").

289. LAUBACH, supra note 38, at 93 (internal quotation marks omitted) (reproducing a resolution adopted at the 1964 Republican Convention).

290. See BoLes, supra note 31, at 315 (discussing support for Engel among high-level educators); JoHNSON, supra note 205, at 91-93 (discussing support for Engel among educa- 
President Kennedy also supported Engel, which was no surprise given the fact that he had touted the principles underlying Engel two years before the $\mathrm{Su}-$ preme Court decided it. ${ }^{291}$ At a press conference shortly after Engel was decided, Kennedy stated:

I think that it is important for us if we are going to maintain our constitutional principle that we support the Supreme Court decisions even when we may not agree with them.

In addition, we have in this case a very easy remedy and that is to pray ourselves. And I would think that it would be a welcome reminder to every American family that we can pray a good deal more at home, we can attend our churches with a good deal more fidelity, and we can make the true meaning of prayer much more important in the lives of all of our children. ${ }^{29}$

Kennedy's comments were careful, measured, politic. But that sort of support made sense in light of the fury that followed Engel; Kennedy was a politician.

That said, the support that mattered most in Engel came from what might seem a surprising source: the nation's religious establishment. ${ }^{293}$ In statement after statement, leaders of the largest denominations took the Supreme Court's side, and the reason was most always the same-Engel was a "blow against formalism,"294 invalidating a prayer that was "of necessity so neutral, so interdenominational, so nonsectarian that it was simply not a religious utterance

tion specialty magazines appealing to a well-educated readership); Opinion of the Week: Proyers in School, supra note 20 (quoting the U.S. Commissioner of Education as supporting Engel); Prayer Ban Backed by Education Aides, N.Y. TIMES, July 2, 1962, at 26 (discussing support for Engel by the President of the National Education Association and the Secretary of the Educational Policies Commission).

291. See supra text accompanying note 85 .

292. The President's News Conference, 1 PuB. PAPERS 509, 510-11 (June 27, 1962). To see the press conference, and how President Kennedy used intonation to communicate support for Engel, see British Pathé, President Speaks on Prayer Banning in U.S. Schools (1962), YouTube (Apr. 13, 2014), https:/www.youtube.com/watch?v=F0sPUpj7Fac.

293. One might have thought that the religious establishment would support school prayer because it was proyer, especially in light of the ecumenical nature of the Regents' Prayer. In addition, one might have thought that whatever fears the public had about the implications of Engel for religion in American society, the religious establishment would have felt them tenfold.

294. Paul A. Friedrich, A Sermon (n.d.) (Hugo LaFayette Black Papers, Box 354) (underlining omitted). "The prayer sounds like a Boy Scout oath," the Executive Secretary of the Synagogue Council of America said. "It's a downgrading prayer." The Court Decisionand the School Prayer Furor, supra note 16, at 45 (internal quotation marks omitted); see also Hearings, supra note 288, at 659 (quoting Edwin H. Tuller, General Secretary of the American Baptist Convention, as stating, "It is because of a deep respect for rcligion, and the recognition that prayer is essential and should be a vital encounter between man and God, that Baptists oppose devotional exercises that are more rote than worship"); Emmet John Hughes, Schoolrooms and Prayers, NEWSwEEk, July 1, 1963, at 15, 15 ("None of the nation's 83 larger religious bodies would confess that the vigor of its faith depends on the rather perfunctory recitation of a schoolroom prayer. And many a religious leader sensibly views such routine rituals as more likely to blur than to focus religious feeling."). 
worthy of the name."295 That kind of prayer wasn't good for prayer, religious leaders stated, and in a pluralistic society, there was no other kind it could be. "When the positive content of faith has been bleached out of prayer," said one church spokesman, "I am not too concerned about retaining what is left." 296 Others agreed, ${ }^{297}$ including the nation's two leading Protestant magazinesone liberal, one conservative. ${ }^{298}$ Within two months, the National Council of Churches, which purported to speak for thirty-one Protestant denominations and forty million members, weighed in on Engel, praising the Supreme Court for "guard[ing] against the development of 'public school religion' which is neither Christianity or Judaism but something less than either." 299

Within the religious establishment, that left just Catholics and Southern evangelicals against Engel-and their denunciation of the decision was fierce. ${ }^{300}$ Catholics in particular were among Engel's most vehement critics. ${ }^{301}$

295. Ruling on Prayer Upheld by Rabbis, N.Y. TLMEs, July 1, 1962, § 1, at 48 (quoting Rev. Dr. Joseph H. Lookstein).

296. See The Court Decision-and the School Prayer Furor, supra note 16, at 45 (internal quotation marks omitted) (quoting the President of the Lutheran Church in America).

297. For example, the New York Times quoted Presbyterian Life, "the official magazine of the 3,260,000-member United Presbyterian Church," as saying, "If you have faith-ingeneral, you have no faith to speak of. Faith has to be in something-in-particular. A nondenominational prayer is doomed to be limited and circumscribed. If prayer starts soaring, it starts to be controversial, which is one thing a nondenominational prayer dares not be." Prayer Ban Wins Church Backing, N.Y. TIMEs, Aug. 13, 1962, at 35 (internal quotation mark omitted); see also Ruling on Prayer Upheld by Rabbis, supro note 295 (quoting one rabbi as saying that "nothing is more likely to rob prayer of its most profound purpose than a prescribed and uninspired invocation" (internal quotation mark omitted)).

298. See On Second Thought ..., TTME, Aug. 24, 1962, at 40, 40 ("Church magazines as different as the liberal Christian Century and the conservative Christianity Today have backed the court nuling."), see also id. (quoting Presbyterian Life as supporting Engel, stating that the Regents' Prayer "was really a rather limited, circumscribed prayer directed to a limited, circumscribed God" (internal quotation marks omitted)).

299. Alexander Burnham, Edict Is Called a Setback by Christian Clerics-Rabbis Praise It, N.Y. Times, June 26, 1962, at 1 (quoting the Director of the National Council of Churches' Department of Religious Liberty); see also Crawford, supra note 209, at 36 (noting membership numbers and approval of Engel by the National Council of Churches).

300. See Kirk W. Elifson \& C. Kirk Hadaway, Prayer in Public Schools: When Church and State Collide, 49 PUB. OPnNION Q. 317, 319 (1985) (describing Southem evangelicals as "those who are most vocal in pushing for constitutional amendments," and noting that they "favor allowing prayer in public schools by a margin of 94 to 6 percent"); Jeffries \& Ryan, supra note 26, at 323 ("The coalition of Protestants, Jews, and secularists produced a remarkable array of elite opinion in favor of the Supreme Court's school-prayer and Bible rcading decisions. This coalition left out conservative evangelicals-who were then less numerous, less well organized, and far less influential than today-and Roman Catholics." (footnote omitted))

301. See Beaney \& Beiser, supra note 221, at 482 ("Roman Catholic spokesmen were extremely critical of the Court... [T] [Te Jesuit weekly America used the adjectives "asinine,' 'stupid,' 'doctrinaire,' and 'unrealistic." (quoting Kurland, supra note 162, at 2 n.5)); Kurland, stupra note 162, at 2 ("The Catholic hierarchy and its spokesmen were almost unan- 
Indeed, reports of religious opposition to Engel almost always quoted Catholic leaders to prove the point. ${ }^{302}$ Given the fact that Catholics had historically decried religious observances in public schools, and even drove much of the litigation to enjoin such practices, ${ }^{303}$ the question is why. Why did Catholics condemn Engel when they had complained for so long about school prayer?

As a number of contemporary commentators observed, the answer almost certainly had more to do with financial aid to parochial schools than school prayer per se. ${ }^{304}$ As Catholics came into their own, their priorities shifted from wanting (Protestant) religion out of public schools to wanting public funding for religious schools of their own. ${ }^{305}$ Engel undercut that position in two ways. First, it took away Catholics' chief complaint-that religious observances made public schools inhospitable for children of the Catholic faith. ${ }^{306}$ Second, it added another brick to the wall of separation between church and state-culturally,

imous in condemnation of the Court in most vehement terms."); Burnham, supra note 194 ("Roman Catholic opinion was particularly strong in opposition to the court's decision.").

302. See, e.g., Bumham, supra note 194 (quoting multiple cardinals opposed to Engel); Burnham, supra note 299 (same); George Dugan, Clergy is Divided on School Prayer, N.Y. TIMES, July 9, 1962, at 51 (discussing Roman Catholic opposition); School Prayer Ban Scored at Red Mass, supra note 154 (discussing a Jesuit priest's remarks); Spellman Renews Atack on Court's Decision, N.Y. TIMES, June 28, 1962, at 17 (discussing Cardinal Spellman's vigorous attack on the Supreme Court's school prayer ruling).

303. See BoLES, supra note 31 , at 220 ("When examining the attitudes of Roman Catholics regarding Bible-reading practices in the public schools, one fact in particular stands out: Most of the litigation seeking to enjoin such exercises bas been brought by Catholic and Jewish citizens."); SoLomon, supra note 31, at 319 (stating that the Roman Catholic Church"s opposition to Engel was "a reversal of the position it held for a century"); Gordon, supra note 66, at 1216 ("Engel and Schempp created a new fault line when Catholics, who had long complained that reading the King James Bible was hardly an ecumenical approach to religion, rallied around the concept of prayer as key to education in a democracy.").

304. See, e.g., The Court Decision-and the School Proyer Furor, supra note 16, at 45 (" (An attorney] added that the decision "makes it clear that Federal funds may not be used to finance parochial-school education.' The nuling may mean no such thing, but, judging from their heated response, the point was not lost on Catholic leaders, who favor church-school aid."); Lewis, supra note 234 ("The critics may have reacted as bitterly as they did because they felt the decision did foreshadow rulings against [parochial school] assistance.'). Similarly, the New York Times quoted the New York Post as writing, "The indignation of the Catholic hierarchy is understandable. It is prompted, we suspect, not by the prohibition of a prayer which many churchmen would agree had little religious value, but by the potential impact of the decision on the aid-to-education battle." Excerpts from Editorials on School Praver Decision, supra note 207. Indeed, a Catholic was on the interdenominational committee that wrote the Regents' Prayer. See supra note 95 and accompanying text.

305. See BoLEs, supra note 31, at 228 (noting Catholic preference for a "system of taxsupported parochial schools" to overcome the various drawbacks to religious education in public schools); GREEN, supra note 31, at 83 (noting a tum in the wake of the Philadelphia "Bible Riots" from "seeking to resolve the Bible reading issue in the public schools" to "creating parochial schools to serve the growing number of Catholic children").

306. In faimess, this was a minor point, as Engel provided a new claim to make: public schools were secular, and that was inhospitable for Catholics too. 
politically, jurisprudentially. ${ }^{307}$ In short, Catholics genuinely hated Engel, but not because they loved school prayer. Catholics hated Engel because of what it meant for them.

As time passed, however, the religious landscape shifted. By the start of the congressional amendment hearings in the spring of 1964, mainstream Protestant support for Engel had hardened and was virtually unanimous. ${ }^{308}$ And the Catholic position on Engel had moved from vehement opposition to "guarded approval." ${ }^{309}$ Even Southem evangelicals had split, with some supporting efforts to amend the Constitution and others concluding that the Supreme Court had been right. ${ }^{310}$ In the end, almost every mainstream denomination in the United States went on record in favor of Engel, with over thirty presenting testimony before Congress. ${ }^{311}$ The consensus was clear-prayer that was "more rote than worship" was not prayer worth praying, ${ }^{312}$ and in a world of religious pluralism, that was all that was left.

With the religious establishment's testimony in Congress, momentum to amend the Constitution first slowed, then went the other way. ${ }^{313}$ To be fair, others played a part too; a petition signed by 223 law professors, for example, was thought to have had sway (at least among law professors). ${ }^{314}$ But it was

307. See Berg, supra note 65 , at 126-27 ("While the bishops clearly supported public school prayer itself (which had become less Protestant and more ecumenical over the years), they almost eertainly were looking beyond the issue: their chief concern lay in establishing church-state 'cooperation' rather than separation as the rule for future school aid disputes.").

308. See A Tide Reversed, supra note 284, at 62 ("Almost evcry Protestant denomination-ranging from the Seventh-day Adventists to the Episcopal National Council-has gone on record endorsing the decisions.").

309. Id. Perhaps Justice Brennan's concurrence in Schempp made a difference. See infra notes 349-52 and accompanying text (discussing Justice Brennan's stated intent to use his concurrence to speak to the Catholic Church); see also James O'Gara, Prayer in School, 80 COMMONWEAL 442, 442 (1964) (discussing results of a poll of 48 Catholic cditors, 35 of which opposed an amendment overturning Engel, and listing the reasons given as "[ $r]$ eluctance to resort to constitutional amendment; concem over weakening of chances for aid to parochial schools should the amendment be enacted; the view that public school devotions with proper concern for all involved are a practical impossibility; and the fear that many parents would consider school prayers as adequate religious instruction for their children" (internal quotation marks omitted)).

310. See Green, supra note 274, at 564. For a discussion of how Engel fundamentally realigned the traditional Protestant-Catholic split, creating a new coalition of conservative Protestants and Catholics, see Gordon, supra note 66, at 1210-19.

311. See GoLD, supra note 48 , at 126.

312. Hearings, supra note 288, at 659 (quoting Edwin H. Tuller, General Secretary of the American Baptist Convention); see also LAUBACH, supra note 38, at 54, 78, 81 (quoting congressional testimony opposing a constitutional amendment to allow nonsectarian prayer on the grounds that such prayer was inherently "ioutine, casual, and indiscriminate, in the same category with algebra and spelling," "a theological caricature at best or a thcological monstrosity at worst," and a "trivial inconvenience" to get out of the way before getting to the important work of the day (internal quotation marks omitted)).

313. See A Tide Reversed, supra note 284 , at $60,62,65$.

314. See Beaney \& Beiser, supra note 221, at 500 . 
church opposition to state-sponsored religion that formed the comerstone of the anti-amendment position and religious support for Engel that ultimately won the day. ${ }^{315}$

In part, church testimony was important because it made people think about what nonsectarian prayer looked like in a religiously diverse society; in part, it was important just for the signal it sent. Members of Congress confided that before church leaders testified, it would have been political suicide to oppose calls for an amendment. ${ }^{316}$ The question had been framed as "whether one is for prayer or against it," and the answer to that was easy, especially in an election year. ${ }^{317}$ What religious leaders showed was that the question was not that simple, and it was also not true that only the godless opposed God in public schools. ${ }^{318}$ Once backed by the religious establishment, congressmen could respectably oppose school prayer if they wanted. And they did.

What the support of religious (and other) elites in Engel might tell us about the nature of Supreme Court controversies more broadly is a question I explore below. For now, suffice it to say that elites played a distinctly educative role in Engel, and it was critical in preserving the case. For the Supreme Court's at-

315. See ld. (describing religious opposition as "the major factor which tipped the balance against the [pro-amendment] forces"); Sullivan, supra note 286 ("Church opposition to a state-sponsored 'homogenized' religion has been the comerstone of the case against other prayer amendment proposals.").

316. See BOLES, supra note 31, at 299 ("A number of congressmen privately confided to this author that if the discharge petition had been successful the amendment would have passed the House of Representatives since many members of the House felt it was impossible politically to oppose the amendment despite personal views to the contrary."); Beaney \& Beiser, supra note 221 , at 496 (quoting an unnamed "powerful Southern committee chairman" as saying, "I have been somewhat silent on the subject matter, waiting for the hysteria to subside," and noting that "Congressman Becker put additional pressure on his colleagues by threatening to come into the district of every congressman who failed to support his amendment and actively campaign against him in the forthcoming election" (internal quotation marks omitted)).

317. BOLES, stipra note 31 , at 254 (paraphrasing testimony of the Executive Director of the Baptist Joint Committee on Public Affairs); see also Beaney \& Beiser, supra note 221, at 496 ("In an election year, no Congressman wanted to be placed in a position of appearing to vote against God, which was exactly the role into which supporters of the Court were being forced."). As one Representative, an opponent of an amendment, said, "[T]he question before us now is, 'Do we want to change the First Amendment?' It must be discussed without any suggestion that those who seriously question any change are somehow anti-God, or antichildren or antimother." New Uproar over School Prayers, U.S. NEWS \& WORLD REP., May 4, 1964, at 12, 12 (internal quotation mark omitted).

318. See DeLFatTORE, supra note 36, at 115-16 ("Above all, [amendment opponents] were determined to neutralize the perception that a vote against the amendment would be a vote against God ... [T] his activism encouraged anti-amendment members of Congress to speak out, since they could refute the charge of ungodliness by pointing to all the religious leaders and legal experts who shared their view."); see also Beaney \& Beiser, supra note 221 , at 497 (noting that "the most important function" that the religious establishment served at the hearings was "to make it 'respectable' and 'safe' for Congressmen to oppose the Becker proposal"). 
tempt to play an educative role of its own, I turn to its 1963 decision in School District of Abington Township v. Schempp.

\section{The Supreme Court Responds: School District of Abington Township v. Schempp}

The Supreme Court's 1963 decision in School District of Abington Township v. Schempp, ${ }^{319}$ which struck down Bible reading and recitation of the Lord's Prayer in public schools, is typically viewed as a continuation of the Court's countermajoritarian streak in Engel. Not only did the Justices decide Engel, but in its wake, they did the most bold, brave thing they could do: they took another school religion case and again invalidated religious observances in public schools. ${ }^{320}$ So stated, Schempp doubles down on Engel's countermajoritarian narrative, showcasing the Court's capacity to stand firm even as threats of a constitutional amendment were hurled against it. Yet here again, the historical record reveals a different reality.

The story starts with the Supreme Court's decision to take Schempp in the first place-or, more accurately, its lack thereof. Missed in most of the commentary on Schempp is the fact that the case was a direct appeal from a threejudge district court panel, a mechanism that at the time conferred mandatory jurisdiction upon the Supreme Court. ${ }^{321}$ Thus, while it is true that the Court decided Schempp in Engel's wake, the reality is that it had no choice. ${ }^{322}$

319. 374 U.S. 203 (1963).

320. ALLEY, supra note 17 , at 120 ("In the midst of this public uproar the Court assembled for the fall and straight away agreed to hear appeals of two cases involving prayer and Bible reading in public schools .... "); PETtER IRONS, A PEOPLE'S HISTORY OF THE SUPREME CouRT 411 (2006) ("The justices could easily have denied review in Abington Township $v$. Schempp, which differed from Engel only in the text of the classroom prayer. Most likely, they wanted to tell the politicians who demanded a constitutional amendment to reverse Engel that the Court stood firm in the face of pressure."); Lewis, supro note 234 ("Few Supreme Court decisions in recent years have aroused so much public anguish as the case of the New York Regents prayer. ... Now, as one of the first acts in their new term, the justices have agreed to take a fresh look at the broad problem of religion in the public schools.").

321. See Sch. Dist. of Abington Twp. v. Schempp, 371 U.S. 807 (1962), noting prob. juris. in $201 \mathrm{~F}$. Supp. 815 (E.D. Pa. 1962). For a history of the three-judge district court, which was established to hear claims against the state for injunctive relief on constitutional grounds, and a discussion of the mandatory appellate jurisdiction that came with it, see Michael E. Solinine, Congress, Ex Parte Young, and the Fate of the Three-Judge District Court, 70 U. PITT. L. REV. 101 (2008).

322. The Schempps continued to have children in school throughout the litigation, so not even taxpayer standing, which had provided the Justices an out in other early school religion cases, was available. See Schempp, 374 U.S. at 206 (noting that two of the Schempp children were current students and that another was originally a party but graduated and thus was voluntarily dismissed from the suit); supra note 119 (citing dismissal of Doremus for lack of standing). Not even Alexander Bickel's "passive virtues" could have helped the Justices avoid Schempp, as jurisdiction in the case was mandatory. See Alexander M. Bickel, 
In fairness, the Supreme Court did have a choice in taking Murray $v$. Curlett, ${ }^{323}$ the companion case to Schempp. The plaintiffs in that case were William J. Murray III and his mother, Madalyn Murray - an outspoken and controversial atheist who would later become known as "The Most Hated Woman in America." ${ }^{324}$ In the wake of Engel, just the fact that the Court granted certiorari in Murray suggests some modicum of bravery.

But not much. Although Murray arrived at the Supreme Court first, the Justices did not grant certiorari in the case until the day they recognized jurisdiction in Schempp. ${ }^{325}$ Even then, there was substantial discussion among the Justices as to whether both cases could be summarily disposed of under Engel. ${ }^{326}$ Ultimately, they decided against summary disposition because the state in Schempp and Murray had not actually composed the religious observances at issue. ${ }^{327}$ The cases would need to be considered on the merits, and " $[\mathrm{b}]$ ecause of the striking similarity in the facts and the identity of the basic issue," ${ }^{328}$ they would need to be considered together.

Yet even as a companion case, the Justices' treatment of Murray is telling. Murray's case number at the Supreme Court came before Schempp's, which should have resulted in the consolidated cases being styled under the caption of Murray v. Curlett. ${ }^{329}$ But that is not what the Justices did; they gave Schempp the lead case name instead. Indeed, the first draft of the Court's opinion did not mention the name "Murray" at all, referring to the case by its case number and to the Murrays as "petitioners" instead ${ }^{330}$ The move was, to borrow from journalism professor Stephen Solomon, "like overlooking a town fireworks display

The Supreme Court 1960 Term-Foreword: The Passive Virtues, 75 HARv. L. REv. 40, 4042 (1961) (discussing passive virtues in light of the 1960 Supreme Court term).

323. 374 U.S. 203 (1963).

324. Jane Howard, 'The Most Hated Woman in America, 'LJFE, June 19, 1964, at 91, 91 (internal quotation marks omitted). Ironically, her son William later became an evangelical Christian and picketed her public appearances. See DIERENFIELD, supra note 14, at 186 . For an in-depth discussion of Madalyn Murray and her challenge of school religious observances, see $i d$. at 163-86.

325. Murray's petition for a writ of certiorari was filed on May 15, 1962. The Justices granted certiorari on October 8,1962, the same day they recognized jurisdiction in Schempp. Compare Murray v. Curlett, 371 U.S. 809 (1962), granting cert. to 179 A.2d 698 (Md. 1962), with Schempp, 371 U.S. 807 (noting probable jurisdiction).

326. Chief Justice Warren, along with Justices Brennan and Douglas, thought the cases should be decided summarily under Engel. See SOLOMON, supra note 31, at 265-67 (relating discussion among the Justices as to how the two Bible reading cases should be handled).

327. See id.

328. Tom C. Clark, Draft Opinion at 3, Sch. Dist. of Abington Twp. v. Schempp, No. 142 (May 1963), available at http:/tarlton.law.utexas.edu/clark/view_doc.php?id=al43-10 -01. Both cases challenged Bible reading and recitation of the Lord's Prayer, $I d$. at 3 n.3.

329. Murray's docket number was 119; Schempp's was 142. See Mengler, supra note 241 , at 339 (discussing Murray and Schempp in light of the Court's custom of using the lowest docket number as the style for consolidated cases).

330. See Clark, supra note 328 . 
taking place on your front lawn." ${ }^{331}$ But for a Court under attack, it made sense. Having determined they could not ignore Murray, or summarily dispose of it and Schempp, the Justices did the next best thing they could: they downplayed Madalyn Murray as much as humanly possible. Whereas the facts of Schempp spanned seven pages (beginning with the introduction of the named plaintiffs as devout Unitarians), the facts of Murray were relegated to two short paragraphs, appearing almost as an afterthought in the case. ${ }^{332}$

On the law, Schempp was easy. In fact, a number of the Justices including Justice Stewart-recognized that the daily devotionals at issue in the companion cases were even more of an Establishment Clause violation than the state-written prayer in Engel. ${ }^{333}$ Bible reading and recitation of the Lord's Prayer were unequivocally sectarian, and the state was sponsoring their use. ${ }^{334}$ "Unless we reverse [Engel] we must reverse here," Chief Justice Warren stated in conference, and only Justice Stewart disagreed. ${ }^{3.35}$ Justice Stewart thought that between the two religion clauses, "[t]he free exercise clause is the important one." ${ }^{336}$ As long as individuals had toom to go their own way, he argued, what the state did (or did not do) by way of daily devotionals was not constitutionally significant. Once again, he was the lone dissenter. ${ }^{337}$

Although on the law Schempp was easy, the public relations aspect of the case made it hard. "This issue is a heated one," Justice Goldberg stated in conference, noting that the public would need to be "reassured." 338 And that is exactly what the Justices in Schempp set out to do.

The Justices' efforts at reassuring the public in Schempp started with who was assigned to write it: Tom Clark. Unlike Justice Black, Justice Clark was one of the Warten Court's core conservatives, a man who could be counted on to write a careful, centrist opinion that minimized misunderstanding and emphasized the limits of the case. ${ }^{339}$ In addition, Justice Clark's hardline anti-

331. Solomon, supra note 31 , at 288.

332. See Sch. Dist. of Abington Twp. v. Schempp, 374 U.S. 203, 205-13 (1963).

333. In the conference on Murray, Chief Justice Warren stated, "This case is stronger than that case was. This is a violation of the establishment clause." SUPREME COURT IN CONFERENCE, supra note 16, at 425. Justice Stewart stated, "This is more of an establishment clause case than [Engel v.] Vitale. This is sectarian." Id, at 426 . And in the conference on Schempp, Justice Goldberg stated, "[T]his is a much more religious prayer than the one in Vitale." Id.

334. Once again, the State essentially conceded the point. See Schempp, 374 U.S. at 210 (noting that the State's expert testificd that the Bible was nonsectarian but upon further questioning "stated that the phrase "non-sectarian' meant to him non-sectarian within the Christian faiths").

335. See SUPREME COURT IN CONFERENCE, supra note 16, at 425-26 (quoting Chief Justice Warren).

336. Id. at 426 (quoting Justice Stewart).

337. See id. at 425-26; see also Schempp, 374 U.S. at 308-20 (Stewart, J., dissenting).

338. SuPREME COURT IN CONFERENCE, supra note 16, at 426 (quoting Justice Goldberg).

339. Justice Black would have been the obvious choice for the assignment to write Schempp; he had authored not only Engel but also Everson and McCollum-two of the three 
Communist efforts while Attorney General made it harder for critics to claim that the Supreme Court was subverting democracy in favor of atheistic Communists, as they had in Engel's wake. ${ }^{340}$ Justice Clark was an ideal choice for yet another reason as well: he had been deeply disturbed by the press corps' handling of Engel and was certain to be attentive to the public relations aspect of the case. ${ }^{341}$ In the aftermath of Engel, that was (almost) the entire point.

The difference was palpable. If any one line of the opinion in Schempp captured its overriding theme, it was this: "The place of religion in our society is an exalted one. ${ }^{1342}$ And in Schempp, the Supreme Court's nod to religion was not just abstract. It was punctuated with references to religious practices in public life--oaths of office, legislative prayer, military chaplains, the Court crier's announcement at the beginning of each session of the Supreme Court-all of which were cited with reverence. ${ }^{343}$ By design, the opinion in Schempp left no doubt about the Court's respect for religion and no room for an overly broad interpretation of the case.

A close second by way of overarching themes in the Schempp opinion was the importance of religious freedom in a religiously diverse society. Here again, the opinion made abstract ideals concrete, providing data on religious diversity and explaining how respect for pluralism was a core component of the religious freedom that marked the American way ${ }^{344}$ And whereas Engel had not cited a single case, Schempp referenced a veritable catalog of Supreme Court precedent, citing case after case to bolster its point. ${ }^{345}$ The Constitution required "strict neutrality," the Supreme Court explained, not because it was against religion, but because the First Amendment was for it. ${ }^{346}$

Rounding out the majority's opinion in Schempp were three concurrences—one each by Justices Douglas, ${ }^{347}$ Brennan, ${ }^{348}$ and Goldberg. ${ }^{349}$ For purposes of the present discussion, Justice Brennan's seventy-page concurring opinion is most worthy of note, if only because he asked the other Justices not

prior school religion cases. See SOLOMON, supra note 31, at 284-85 (discussing the tactical assignment of the Schempp opinion to Clark); supra note 134 (listing the three school religion cases prior to Engel); see also Powe, supra note 14, at 359 (noting that Justice Clark was assigned the Schempp opinion in part because he was "a conservative, not a crazy").

340. See Solomon, supra note 31 , at 285.

341. See supra notes 265-68 and accompanying text (discussing Justice Clark's public comments about Engel).

342. 374 U.S. at 226; see also Lewis, supra note 157 ("[The Justices in Schempp] bent over backwards to praise the role of religion in this country. Thcy made clear-as they had not entirely done a year ago-that a ban on the use of the public school classroom for devotionat exercises did not mean the rooting out of other religious elements from public life.").

343. See 374 U.S. at $212-13$.

344. See id. at 214-15.

345. See id. at 215-21.

346. See id. at 225 .

347. Id. at 227 (Douglas, J., concurring).

348. $I d$. at 230 (Brennan, J., concurring).

349. Id at 305 (Goldberg, J., concurring). 
to join it. ${ }^{350}$ Justice Brennan wanted to appeal to a Catholic audience as a Catholic, and for that he felt the opinion needed to be his and his alone. ${ }^{351}$ There could be no doubt as to where he stood. "[N]ot every involvement of religion in public life violates the Establishment Clause," Justice Brennan explained, noting that Schempp said nothing about church-state issues such as "the propriety of certain tax deductions or exemptions which incidentally benefit churches and religious institutions." ${ }^{352}$ One could almost hear the Catholic sigh of relief.

The difference between the Engel and Schempp decisions was not lost on the media, which credited the Justices for having "learned a bit about public relations" since $1962 .{ }^{353}$ In every part of the Schempp opinion--from its caption, to its recitation of the facts, to its recognition of religion's importance, to its celebration of religious diversity-the Court communicated with the public in mind. Even the fact that a Protestant, a Catholic, and a Jew each wrote an opinion in the case sent a signal of religious solidarity that did not go unnoticed. ${ }^{354}$ As Thomas Mengler has noted, Schempp was nothing if not a public relations exercise; "[r]eading the Schempp decision as an ordinary example of Court reasoning, therefore, misses the point" of what the Justices were trying to do. ${ }^{355}$

350. See SeTh Stern \& STEPHEN Wermiel, Justice BRENnAN: Liberal CHAMPION 173 (2010) ("Brennan showed the seventy-page final product to his fellow justices in May 1963 after two and a half months of effort. He made clear to his colleagues that he wished this to be his statement alone. He would accept no offers to join the opinion.").

351. See CRAY, supra note 141, at 407 ("Brennan, the sole Catholic on the court, asked that no one else join him. He was, in effect, appealing as a communicant to the hierarchy of the Catholic Church in America and to influential laymen for their support."); STERN \& WERMIEL, supra note 350 , at 173 ("Brennan specifically sought to explain to a Catholic audience what justified his breaking with what he viewed as the Church's position.").

352. 374 U.S, at 294, 301 (Btennan, J., concurring).

353. A Loss to Make Up for, supra note 189, at 13; see also Kaufman, supra note 234, at 50 (noting that Schempp was "[w]ritten much more with an eye toward public perusal and in anticipation of public criticism"); Lewis, supra note 157 ("The Court, for its part, has seldom shown awareness of public opinion more plainly than in its handling of the new prayer cases that came down this week."); Editorial, Moral Heritage and the Law, LıFE, June 28, 1963 , at 4, 4 (noting that the Schempp opinion "show[ed] that the Court has deeply pondered the public fears as well as the legal arguments surrounding the casen); CBS Reports: Storm over the Supreme Court Part III; Bible Reading in the Public Schools (CBS television broadcast June 19,1963 ) ("[T]he Court itself has taken a lesson from last year's reaction, and has pitched the scveral opinions to the attitude of the public in full awareness, in fuller awareness, indeed, than a year ago, of the delicacy of this issue in the public mind." (quoting Harvard Law School professor Paul Freund)).

354. Church and State, supra note 153, at 48 ("Justice Clark, a Protestant, was supported by the opinions of Justice William O. Douglas, Justice William J. Brennan, the Court's only Roman Catholic, and Justice Arthur Goldberg, the Court's only Jew."); Anthony Lewis, 2 Cases Decided, N.Y. TIMES, June 18, 1963, at 1 ("It was particularly noted by courtroom observers that the voices of a Protestant, a Catholic and a Jew on the Court spoke up for the principle of church-state separation.").

355. See Mengler, supra note 241 , at 345. 
To some extent, it worked. Despite the "shudder of apprehension" that marked the Supreme Court's consideration of $S c h e m p p,{ }^{356}$ and the fact that the Court's ruling had a far broader reach than Engel, reaction to Schempp was decidedly mild. ${ }^{357}$ Headlines were mostly favorable. ${ }^{358}$ Media outlets quoted the portions of the opinion that recognized the importance of religion and limitations of the decision. ${ }^{359}$ And the same newspapers that had taken an editorial position against Engel in 1962 now favored Schempp ${ }^{360}$ Indeed, one study of 185 editorials written in the aftermath of Schempp revealed that sixty-one percent supported the Supreme Court's decision. ${ }^{361}$

Not surprisingly, most religious leaders also supported Schempp. By 1963, many mainstream Protestants had come to the conclusion that Bible reading, like school prayer, led to "indoctrination or meaningless ritual,"362 and as such, had issued statements against the practice even before the Supreme Court issued its ruling. ${ }^{363}$ As with Engel, Jews were strong supporters of Schempp,

356. Westin, supra note 182 , at 30.

357. See Beaney \& Beiser, supra note 221 , at 483 ("A careful observer concluded that 'the reaction in the total American community to the ruling was markedly more positive than it had been to the Court's decision in the Regent's Prayer case one year earlier." (quoting Memorandum from Amold Forster, Dir, Civil Liberties Div., Anti-Defamation Lcague, to All ADL Regional Offices 1 (July 11, 1963)); Kaufman, supra note 234, at 51 ("Public commentary, on the whole, was more moderate in tone."); Congress Reacts Mildly to Ban; Some Ask Amendment to Kill It, N.Y. TIMES, June 18, 1963, at 27 (noting that congressional reaction to Schempp "was much milder today than it was after a similar decision a year ago"); A Loss to Make Up for, supra note 189, at 13 ("Last weck, when the Supreme Court issued a far broader ban on religious observances in schools, the reaction was relatively mild."). Indeed, a mild public reaction was anticipated even before Schempp was announced. See Anthony Lcwis, High Court Ruling on School Prayer Is Expected Today, N.Y. TIMEs, June 17,1963 , at 1 ("The initial public rcaction to the prayer decision a year ago was highly critical. However, opinion has evidently shifted to a significant extent.").

358. See JoHNSON, supra note 205, at 81 tbl.4, 82 (noting a "qualitative difference between these headlines and those of the year before" and providing a table of newspaper headlines on Schempp, including "Religious Freedom Protected by the Court," "Jefferson Sustained," "Court Decision Draws Mild Reaction," "Congressional Court Critics Less Angry," and "Church Reaction to Court Decision Mostly Favorable").

359. See id. at 80 (discussing newspapcr coverage of Schempp in detail and concluding that "ncws services, then, were quick to pick up the portion of Clark"s dicta which explicitly stated the limits of the ruling and which acknowledged the traditional place of religion in American society").

360. See id. at 82 ("The change in tenor was perhaps even more pronounced on the editorial pages. In 1962 all the newspapers which took an cditorial position opposed the Engel ruling, while in 1963 the same newspapers ... favored the Schempp decision.").

361. See Beaney \& Beiser, stpra note 221 , at 483.

362. Green, supra note 274 , at 553 (quoting articles published in Christianity Todoy and Presbyterian Life in 1963)

363. See Sch. Dist. of Abington Twp. v. Schempp, 374 U.S. 203, 284 n.61 (1963) (Brennan, J, concurring) (quoting the May 1963 issue of the Episcopalian as stating that "prayer and Bible reading are too sacred to be permitted in public schools"); id. at 284-85 (quoting the Baptist Joint Committee on Public Affairs as stating, "When one thinks of prayer as sincere outreach of a human soul to the Creator, 'required prayer' becomes an absurdi- 
while Catholics and fundamentalists were strong opponents. ${ }^{364}$ Even so, Catholic criticism of Schentipy was more restrained than it had been of Engel, ${ }^{365}$ and by 1963, some of Engel's critics had changed their minds. "Unlike last year, ... when I reacted emotionally, illogically, and non-intellectually," one church spokesman told the press, "this decision doesn't disturb me."366

This is not to say Schempp was popular by any stretch. Members of Congress submitted almost twice as many proposals for a constitutional amendment as they had in response to Engel. ${ }^{367}$ Southerners renewed vows of noncompliance. ${ }^{368}$ And public opinion polls continued to show overwhelming support for religious observances in school, ${ }^{369}$ although there was some indication that the

ty" (quoting Editorial, Religion Sponsored by the State, 4 J. CHURCH \& ST. 141, 144 (1962)) (internal quotation marks omitted)); $i d$. at $286 \mathrm{n} .65$ (quoting a May 1963 draft policy statement of the National Council of the Churches of Christ that "neither true religion nor good education is dependent upon the devotional use of the Bible in the public school program" (quoting Susanna McBee, Bible Use in Schools Criticized, WaSH. Post, May 25, 1963, at A1)), SoRAuF, supra note 105, at 302 (noting a June 7, 1963, resolution passed by the National Council of Churches by a vote of 65 to 1 opposing religious observances in public schools).

364. See George Dugan, Churches Divided, with Most in Favor, N.Y. TmEs, June 18, 1963, at 1; see also Billy Graham Voices Shock over Decision, N.Y. TIMEs, June 18, 1963, at 27; Rabbis Acclaim Prayer Decision, N.Y. TIMEs, June 23, 1963, \$1, at 65.

365. See Beaney \& Beiser, supra note 221 , at 484 ("Whereas expressions of opinion by Catholic leaders after Engel had been almost uniformly critical, several Catholic Bishops and Archbishops now issued statements calling for restraint."); see also Editorial, The Court Decides Wisely, 80 CHRISTIAN CENTURy 851, 851 (1963) (discussing a joint statement of twenty-five Protestant, Catholic, and Jewish leaders supporting $S$ chempp).

366. Chtrch and State, supra note 153, at 48 (internal quotation marks omitted).

367. That said, congressional commentary on $S$ chempp was likewise relatively mild. See Congress Reacts Mildly to Ban; Some Ask Amendment to Kill It, supra note 357; see also Beaney \& Beiser, supra note 221, at 492-93 (comparing the number of amendments submitted after cach decision and noting "an interesting paradox: popular reaction to Engel was much greater than the outcry after Schempp; yet at the same time positive political action was much more significant after Schempp than it had been a year earlier").

As to the reason for the disconnect, Beancy and Beiser are likely right: politicians were gearing up for the elections of 1964. See Beaney \& Beiser, supra note 221, at 492-93; see also id. at 496 (noting that Congressman Becker, chief proponent of the school prayer amendment, "put additional pressure on his colleagues by threatening to come into the district of every congressman who failed to support his amendment and actively campaign against him in the forthcoming elcction"). Interestingly, the Supreme Court's school prayer rulings did not play a part in the 1964 presidential elections. See id. at 503 ("But little was made of the prayer issue in the [1964] Presidential campaign save as a small part of a broadside attack on the Supreme Court.").

368. The Schools and Prayer, Newsweek, Sept. 9, 1963, al 82, 82 ("The greatest bitterness has developed in Southern states. In Alabama, there was open defiance. ... ' We are not going to conform,' [Govemor Wallace] said. 'If the courts rulc that we can't read the Bible in some school, l'm going to that school and read the Bible myself.' In Arkansas, State Attorney Gencral Bruce Bennett adviscd the schools to continue devotional exercises.").

369. See 3 GaLLur, supra notc 19 , at 1837 (reporting that seventy percent of rcspondents in a 1963 poll disapproved of the Supreme Court's ruling "that no state or local gov- 
intensity of the public's preferences had faded. Whereas the Justices had received more than 5000 letters in the first month after Engel, they received just 100 in Schempp's wake. ${ }^{370}$

What to make of the generally more muted response to Schempp is hard to say. Perhaps the Supreme Court's opinion made a difference. Or perhaps in the year following Engel, the public had come to understand (or at least accept) the decision on its own. Perhaps the country was more mentally prepared for the ruling, ${ }^{371}$ or the Court's popularity on other issues had insulated it somewhat. ${ }^{372}$ Or perhaps those who were most opposed to the decision had come to understand that low-level noncompliance-business as usual until sued-was the way to go. ${ }^{373}$

Whatever the explanation, the result was a less inflamed public--but for the Justices, enough was enough. It would be almost another twenty years before the Supreme Court would strike down another school religious observance under the Establishment Clause, ${ }^{374}$ leaving Engel and Schempp as bookends of the Court's foray into the saga of school prayer. The question that remains is what a deeper understanding of that saga might tell us about Supreme Court decisionmaking in general, the Court's countermajoritarian capacity in particular, and the role of judicial review.

ernment may require the reading of the Lord's Prayer or Bible verses in public schools" (italics omitted)).

370. See GREY, supra note 242, at 83. Schempp was nevertheless Justice Clark's most controversial opinion during his fourteen-year tenure on the Supreme Court. DIERENFIELD, supra note 14, at 178. For thoughts about why Congress cared more about $\$ c h e m p p$ when the people carcd less, see note 367 above.

371. See School Prayer Is Out, CH. TRiB., June 18, 1963, at 18 ("After the decision a year ago which ruled that it was unconstifutional for the New York state board of regents to prescribe a noncompulsory form of prayer for the schools, the latest decision was predictable."); cf. supra note 174 and accompanying text (noting that Engel came as a surprise).

372. The Supreme Court decided Gideon v, Wainwright, 372 U.S. 335 (1963), on March 18, 1963, recognizing the right to counsel for indigent felony defendants. It was one of the most popular cases of the entire Warten Court era. See Corinna Barrett Lain, Countermajoritarian Hero or Zero? Rethinking the Warren Court's Role in the Criminal Procedure Revolution, 152 U. PENN. L. REv. 1361, $1391-93$ (2004) (discussing Gideon's popularity among the public and in the popular press, as well as the best-selling novel that it inspired in 1964, Gideon's Trumpet).

373. See supra note 223 (discussing the persistence of religious obscrvances in Southern schools despite the Supreme Court's school prayer rulings, and barriers to enforcement actions there).

374. See Wallace v. Jaffree, 472 U.S. 38, 40, 61 (1985) (invalidating a law authorizing teachers to set aside one minute at the start of the school day for a moment of meditation or silent prayer); Stone v. Graham, 449 U.S. 39, 39, 42-43 (1980) (per curiam) (invalidating a statute requiring the posting of the Ten Commandments in classrooms); see also Stein $\mathrm{v}$. Oshinsky, 382 U.S. 957 (1965), denying cert. to 348 F.2d 999 (2d Cir. 1965) (dismissing a suit against a grade school that ordered its teachers to stop having children say grace before eating). 


\section{WHY IT MATTERS}

Having reconstructed the story of Engel, I now turn to why it matters. First I consider, and reject, the heroic, countermajoritarian narrative for which Engel is famous. Then I turn to three other areas of constitutional law in which a reconstructed narrative of Engel has purchase. Engel adds a new strand to a growing body of work on the power of social movements to generate constitutional change. It presents a rare glimpse of the Justices explicitly engaging in the dialogic function of judicial review. And it exposes qualitative differences in the way popular constitutionalism might play out in practice, with implications for the theory itself.

\section{A. The Reality of Engel 's Heroic, Countermajoritarian Narrative}

Engel is a canonical case because by conventional wisdom, it shows that the notion of our Supreme Court defending unpopular minorities against powerful majorities is not just some pointy-headed theory. It actually happens. It happened in Engel.

Here I consider the reality of that heroic, countermajoritarian narrative, but before beginning, I pause for a moment to clarify the terms of the debate. When we talk about the Supreme Court's countermajoritarian capacity, what sort of countermajoritarianism is at issue? And what sort of evidence is fair game in assessing it?

As to the first question, what is not at issue is any doubt about whether the Supreme Court protects unpopular minorities from local majorities. Surely the Court did so in Engel, as it has in countless other cases. But even Congress can do that-witness the Civil Rights Act of $1964 .{ }^{375}$ What is at issue in the current debate about Supreme Court decisionmaking and the role of judicial review is the Court's capacity to stand strong against a national majority, not a local one. ${ }^{376}$ That is the sort of countermajoritarian capacity that only Article III provides, and it is the sort of countermajoritarian capacity that undergirds most every normative theory of judicial review. ${ }^{377}$

The second question-what sort of evidence is relevant in determining majority will in the first place-is trickier. Public opinion poll data, the position of elected representatives and other institutional players, treatment by the popular press-these and other markers of majority will can be skewed (as Engel shows all too well), and yet each is vital to understanding the larger sociopolitical context in which the Supreme Court operates. Each plays a part in gauging the pre-

375. Pub. L. No. 88-352, 78 Stat. 241 (cndified as amended in scattered sections of 28 and 42 U.S.C.).

376. See Barry Friedman, The Birth of an Academic Obsession: The History of the Cotintermajoritarian Difficulty, Part Five, 112 Y ALE. L.J. 153, 174-76 (2002) (discussing the historical roots of using a national majority as the relevant baseline).

377. See U.S. ConsT. art. III, \& 1; Barry Friedman, The Politics of Judicial Review, 84 TEX. L. REV. 257, 279 (2005). 
vailing view. ${ }^{378}$ Thus, in considering the reality of Engel's heroic, countermajoritarian narrative, I do just as I have in reconstructing its history: I consider whatever helps capture the zeitgeist of the moment in which the Court's ruling was made.

Turning now to the merits of Engel's heroic, countermajoritarian narrative, the historical record reveals three truths that controvert our canonical understanding of the case. First, the Justices had absolutely no idea that they were taking on majority will, and indeed all indications are that if they had known, they would not have taken Engel in the first place. Second, the nation's vitriolic reaction to Engel, which forms the foundation for its countermajoritarian narrative, was based on a massive misunderstanding of the case. And third, the sociopolitical context in which Engel was decided was remarkably supportive of the decision on the merits; that is, not only did the Justices believe that the ruling was in line with public opinion, but there is reason to think it actually was.

As to the first point-the Justices' inadvertent heroism in the case-one might wonder why it matters. Why does the Supreme Court have to know that it is taking on a national majority in order to do it? The answer is in what the Court's acts of heroism are supposed to show. We cling to cases like Engel because they assure us that the Supreme Court will protect minority rights even in the face of strong majoritarian pressure the opposite way. This is what Michael Klarman calls the "psychological imperative" of a countermajoritarian Court, and it is powerful indeed. ${ }^{379}$ We need to know that the Court has the courage to take a stand against clamoring majorities, that it is brave enough to protect the unpopular and weak. Countermajoritarianism by accident does not get us there. What the Court does when it thinks the country is behind it says nothing about what the Court will do when it knows it stands alone.

This is the first problem with Engel. Engel is not a story of the Supreme Court bravely standing up to a national majority in the name of minority rights. Engel is the story of a Court that thought its ruling was eminently agreeableso agreeable that it was almost unanimous, so agreeable that it called for little discussion in conference, so agreeable that it did not strike the Court as needing to cite a single case. Indeed, even after the decision, the Justices steadfastly

378. See Corinna Barett Lain, Upside-Down Judicial Review, 101 Geo. L.J. 113,118 (2012) ("[l]dentifying majority will is notoriously difficult. Public-opinion-poll data can be skewed, depending on how questions are asked. Institutional support can reflect elite, rather than popular, opinion. The same can be said of the popular press. Yet each of these measures is vital to understanding the larger sociopolitical context in which the Supreme Court operates....").

379. See Klarman, supra note 26, at 23-24 (discussing "the psychological imperative for believing in the Court's countermajoritarian heroics"). This psychological imperative goes to the heart of most every normative justification of judicial review. Why have an unelected branch making decisions in a representative democracy? Because the Court can (in theory) stand up to tyrannical majorities. Indeed, we have empowered it to do so by constitutional design. See supra note 377 and accompanying text. 
maintained that Engel was a ruling with which few could disagree (at least once properly understood).

It could have been different. If the Supreme Court had struck down school prayer a decade earlier, when the Cold War was at its peak, its decision would have exemplified the judicial bravery that lies at the heart of our countermajoritarian conception of judicial review. But the Justices had two opportunities to invalidate religious observances in school during that time, and they declined them both. ${ }^{380}$ Only after Cold War religiosity had passed, only after Kennedy was elected President, and only after the edifice of Protestantism had fallen did the Supreme Court deem the minority rights at issue in Engel worthy of protection. Indeed, every scrap of the historical record suggests that if the Justices had known just how unpopular Engel would be, they would have been much less willing to step into the fray in the first place.

That brings me to a thought about why the Justices might have been willing to step into the fray with Engel, and the possibility of yet another connection between Engel and Schempp. As it turns out, the Justices knew that Schempp was coning their way on direct appeal. We know they knew because Schempp had already come their way on direct appeal in 1960.38 At that time, the Justices remanded Schempp on a procedural point that they knew as well as anyone would make no difference in the case. ${ }^{382}$ Schempp was coming back. So if the Justices knew Schempp was coming back, as they surely did, why take Engel? Why take the oddball case in which the state wrote the prayer when the Justices were going to have to rule on the more mainstream practice of Bible reading and recitation of the Lord's Prayer in the next year or two?

The answer is necessarily speculative but makes sense: the Supreme Court took Engel to ease the nation into Schempp. ${ }^{383}$ Engel was in many ways low-

380. See supra notes 118 -19 and accompanying text.

381. See Sch. Dist. of Abington Twp. v. Schempp, 364 U.S. 298 (1960) (per curiam). For a discussion of why Schempp came to the Supreme Court on direct appcal, see note 321 and accompanying text above.

382. Schempp initially raised a Free Exercise Clause claim as well as an Establishment Clause claim because there was no provision under Pennsylvania law for children to be excused upon request. On the way to the Supreme Court the first time, the statc statute was amended to allow excusal. As the district court noted on remand, this did nothing to the Establishment Clause claim that had been alleged from the start. See Schempp v. Sch. Dist. of Abington Twp., 201 F. Supp. 815, 817-18 (E.D. Pa. 1962), aff'd, 374 U.S. 203 (1963) (discussing the procedural posture of the casc and the Establishment Clause claim on remand). I even wonder if the Court's remand was an attempt to buy time so that it could dismiss the case on taxpayer standing, as it had done in Doremus in 1952. See supra note 119 (discussing the Doremus case); see also supra note 322 (discussing why dismissal based on taxpayer standing was not an option for the Supreme Court in Schempp).

383. At least one contemporary commentator also recognized this possibility. See Pollack, supra note 98 , at 63 . If our speculation is right, then my colleague Kevin Walsh is also right: those who hated Engel because of its implications (at least for Bible reading) were on to something, and the Justices' mistake was in thinking that they could sneak one by them. I 
hanging fruit. The prayer was written by the state, so it was a particularly easy Establishment Clause case. It was sui generis; there was not another prayer like it in the country. It was so watered down that even the religious establishment hated it. And it did not take sides in the longstanding Catholic-Protestant war over Bible reading. So viewed, Engel is not unlike the cautious steps the Supreme Court often takes when entering into a new doctrinal area-except, of course, that it backfired. The nation's reaction was not what the Justices expected, which brings me to my second point.

The second problem with Engel's heroic, countermajoritarian narrative is what we can make of the nation's reaction to the case, which is not much. Engel's countermajoritarian narrative rests entirely on the nation's hostile reaction to the ruling, but that reaction was mired in misunderstanding over what the Justices actually said. The papers portrayed Engel as a decision that forbade schoolchildren from praying in school, even if they wanted to, even if they did so on their own, and claimed that the Justices were taking aim at all civic references to God next. No doubt these stances were wildly unpopular, but they were not a fair representation of what Engel held.

Evidence abounds that the misunderstanding mattered. Contemporary commentators recognized it. The Justices lamented it. And Congress's attempt to undo Engel with a constitutional amendment that said the same thing as what Engel held only makes sense in light of it. Even the public opinion poll data on Engel was based on questions that failed to mention that it was a state-written prayer that the Supreme Court had invalidated. ${ }^{384}$ Given that this was key to the Court's holding, it is difficult to make much of the polling data, as strong as it is, ${ }^{385}$ or to ignore the possibility that the polls themselves may have contributed to the misunderstanding that swallowed the case.

That said, the historical record reveals that there were two types of understanding that the public lacked in Engel, not one. To see what I mean, consider for a moment why religious and other highly educated cultural elites supported Engel. The conventional explanation--which is also the conventional explanation as to why the Justices decided Engel the way they did-is elite policy pref-

thank Kevin Walsh for our conversations on this and other points, which have made this Article better.

384. Indeed, the 1964 Gallup poll about Engel asked about support for "a constitutional amendment to legalize prayers in public schools," again framing the issue in free exercise terms. See supra notes 19, 271 (providing the text of questions asked in 1962 and $1964 \mathrm{Gal}-$ lup polls).

385. More recent polls have demonstrated the tremendous importance of how the question is asked. See Gash \& Gonzales, supra note 271, at 68 (noting that in the school prayer context, "question wording and survey methodology can have a dramatic effect on results, leading to differences that exceed 30 percentage points between surveys conducted within a relatively brief span of time"); supra note 271 (noting polls showing that support for school prayer in the abstract hovers around $70 \%-80 \%$, while support for "Christian prayer" hovers around 10\% and support for "general prayer," like the prayer in Engel, hovers around 20\%). 
erences. ${ }^{386}$ The Justices are highly educated cultural elites, so the story goes, and highly educated cultural elites tend to take a separatist stance on issues like school prayer. ${ }^{387}$ And that much is true.

But what the historical record shows is that elites may have supported $E_{n}$ gel not because they had elite values, but because they understood it in a way the public did not. The demagogues in Congress did not have "elite values" (at least not of the sort that supported Engel from the start). They started out hellbent on overturning Engel, then changed their minds. What moved them was an appreciation for the intractable problems associated with school prayer in a pluralistic society, an appreciation gleaned only because the amendment process had forced them to think about the issue in concrete terms. ${ }^{388}$ This was the understanding that religious and educated elites had from the start and the one that rank-and-file members of the public largely lacked. ${ }^{389}$ It was an understanding not only of what Engel held, but why.

386. See FRIEDMAN, supra note 5, at 264-65 ("Yet it also is possible that the justices obtained a skewed picture of the public's likely reaction or were more likely to misjudge in this instance. Opposition to school prayer tends to be highest among the better educated and more well-to-do in society."); PowE, supra note 14, at 358 ("There was a dominant view shared by the well-educated-and therefore the justices of the Court-that religion was a private matter, best left to the homes and the churches."); Jeffries \& Ryan, supra note 26 , at 326 ("Not surprisingly (and not for the last time), the justices championed the dominant views of the nation's elite as against popular opinion."); Smith, stpra note 26, at 1015 ("Engel and Schempp imposed a view generally accepted in elite culture but widely rejected in more popular culture.").

387. See Gash \& Gonzales, supra note 271 , at 66 (discussing quantitative studies on support for school prayer, which "find that those supporting school prayer tend to be older, less educated, and politically and socially conservative"); see also Adams, supra note 273, at $482-83$ (same).

388. See supra notes $278-87$ and accompanying text (discussing growing appreciation for the complexity of the issue as the amendment hearings progressed); see also Hearings, supra note 288, at 597 (quoting Representative George Meader as saying that he didn't like the Supreme Court's interpretation of the First Amendment, but that "[w]e have not found the proper language to [overturn it], I admit"); BoLEs, supra note 31, at 328-29 (discussing the changed views of Representative Robert L. Leggett as illustrative of the phenomenon, noting that he had been one of the first to introduce a proposed amendment in Congress but by the end of the hearings urged the Judiciary Committee against it, noting "the absence of an understanding of facts which characterized some who supported the amendment").

Interestingly, the same sort of learning process played out in the $1980 \mathrm{~s}$, in the wake of President Reagan's call for a constitutional amendment to testore school prayer in 1982. Senator Jeff Bingaman was quoted as stating, "If those arguing about this issue in the Chamber cannot themselves agree, then what sort of chaos is going to be visited on every school board, teacher, and child in this country?" FENwICK, stupra note 212, at 154. Senator John Heinz similarly stated, "What we have gone through these past 2 weeks is proof of the difficulty, if not impossibility, of permitting group, vocal prayer without transgressing our strong tradition of religious tolerance and freedom." 130 CONG. REC. 5899-900 (1984). The attempt to pass a school prayer amendment again failed. See FENwICK, supra note 212, at 165.

389. Further support for this thesis comes from polling data that compare support for school prayer in general with support for "Christian prayer" or "general prayer"--questions 
In the wake of Engel, contemporary commentators credited "careful study" of the school prayer issue as the reason most religious leaders favored Engel when most other people did not. ${ }^{390}$ Social science research at the time largely agreed, concluding that the Supreme Court's ruling impacted "the mass public whose capacities for differentiation are lower than those of the attentive elite." "391 When elite opinion differs from that of the public, maybe the difference reflects elite values, but Engel is a reminder that it may reflect differences in the information, and inclination, people have to think through issues instead. ${ }^{392}$ Research shows that public opinion is highly susceptible to media influence, and that issue framing is a primary means by which this influence occurs. ${ }^{393}$ Highly educated elites are subject to media influence too, but research shows that they are more inclined to critically assess information than the average Joe, less subject to undifferentiated emotional views, and better equipped to resist distortions from the media. ${ }^{394}$ That's elitist, you say. And it is. But what if it is true?

that make the public think about the issuc in concrete terms. See supra note 271 (comparing support across different polling questions). Clerk).

390. A Tide Reversed, supra note 284, at 62 (quoting the United Presbyterian Stated

391. Casey, supra note 259, at 14-17.

392. The death penalty is another issue in which these sorts of differences appear to matter. See Furman v. Georgia, 408 U.S. 238, 369 (1972) (Marshall, J,, concurring) (discounting public opinion polls showing support for the death penalty and "[a]ssuming" that with "knowledge of all the facts presently available regarding capital punishment, the average citizen would, in my opinion, find it shocking to his conscience and sense of justice"); Dwight Aarons, The Marshall Hypothesis and the Rise of Anti-Death Penalty Judges, 80 TENN, L. REv. 381, 391-96 (2013) (reporting substantial empitical support for Marshall's claim); Austin Sarat \& Neil Vidmar, Public Opinion, the Death Penally, and the Eighth Amendment: Testing the Marshall Hypothesis, 1976 WIS. L. REV. 171, 171-97 (same).

393. See Stephen M. Engel, Frame Spillover: Media Framing and Public Opinion of a Multifaceted LCBT Rights Agenda, 38 LAw \& SOC. INQUIRY 403, 406 (2013) (reviewing the literature and concluding that "variation in public understanding of and agreement with a judicial ruling cant, to some extent, be gauged by identifying variation in how news media framed the ruling"); $i d$ at 411-12 ("[S]ince citizens' knowledge of the Court is heavily filtered through media coverage, public opinion on legal decisions may be highly susceptible to media influence. ... News media bombard the viewing, listening, and rcading public with different frames, or ways of organizing and emphasizing facts into a coherent story, on a particular subject, thereby creating competing perceptions of the same event." (citations omitted)); Jane S. Schacter, The Pursuit of "Popular Intent": Interpretive Dilemmas in Direct Democracy, 105 YALE L.J. 107, 132 (1995) ("The mass media are widely regarded as 'the primary source of information about public affairs received by most citizens.' Thus, they have formidable powers to frame and shape not only political campaigns, but 'public opinion' more generally." (footnotes omitted) (quoting Michael Margolis \& Gary Mauser, Public Opinion as a Dependent Variable: An Empirical and Nomative Assessment, in manipulating Public Opinton: Essays on Public opinion as a Dependent Variable 365, 366 (Michael Margolis \& Gary A. Mauser eds., 1989))).

394. See Casey, supra note 259, at 6-7 (noting that elites are more attentive to information gathering and also have "better developcd cognitive skills" for critically considering the information they have); Neil Weinstock Netanel, Asserting Copyright's Democratic Principles in the Global Arena, 51 VAND. L. REV. 217, 264 (1998) (arguing that "elites are 
The point has implications well beyond Engel and goes to the heart of our countermajoritarian conception of judicial review. Is a decision still countermajoritarian if it is really just misunderstood? What level of understanding matters, and how do we gauge understanding in a world where partisan media dominates the discourse? I do not pretend to have the answers to these questions, but I do think they should be part of the conversation. At the very least, Engel attests to the importance of looking beyond the standard majoritarian markers and recognizing the role that media and information deficits can play in shaping the public's views. ${ }^{395}$

That leaves a third, and final, problem with Engel's heroic, countermajoritarian narrative: the sociopolitical context of 1962 . When the Supreme Court decided Engel, the notion of public secularism was so widely accepted that John F. Kennedy touted the principle in his successful 1960 presidential campaign. ${ }^{396}$ Contemporary observers talked about a "broad public consensus" that religion was a private matter ${ }^{397}$ and in much of the country, religious observances in public schools had already died out on their own. ${ }^{398}$ Even the Board of Regents that wrote the prayer in Engel had issued a statement maintaining that the religious inculcation of children was best left to the church and home. ${ }^{399}$ In short, not only did the Justices think that Engel was well in line with popular opinion at the time, but there is ample reason to conclude that it actually was.

Upon reflection, this should come as no surprise. Supreme Court Justices are a part of contemporary society; thus, we can and should expect their decisionmaking to be influenced by the dominant societal norms of their time. Indeed, the real surprise is that Engel's countermajoritarian narrative has persisted for fifty years despite an easily accessible historical record to the contrary. Why has Engel's reality been so hard to see? The answer, I believe, is a mindset that routinely fails to consider the indelible historical context in which

themselves heavily influenced by the media," although "politically sophisticated elites tend to treat media coverage more critically than does the mass electorate"). Interestingly, the advent of blogs, Internet news, and other media sources has not changed elites" information advantage. See Ilya Somin, Originalism and Political Ignorance, 97 MinN. L. REV. 625, 643 (2012) ("Although the cost of acquiring information has declined thanks to modern technology, ... the key constraint on political knowledge is not the availability of information, but citizens" willingness to spend time and energy learning and understanding it.").

395. For a modern account of how, as in Engel, the media's focus on a Supreme Court decision's implications impacted public opinion on the more limited holding of the decision itself, see Engel, supra note 393, at 404-30 (discussing the media coverage of Lawrence $v$. Texas, 539 U.S. 558 (2003), and its implications for gay marriage, finding a negative spillover effect on public support for the more limited ruling in Lawrence itself).

396. See supra note 85 and accompanying text.

397. See supra notes 153-54 and accompanying tcxt (quoting contemporary news magazines noting the "widely agreed upon" view that religious instruction was best left to the church and home and a "broad public consensus" that religion was a private matter).

398. See stpra notes $86-88$ and accompanying text.

399. See supra note 156 and accompanying text. 
the Supreme Court operates. When we ignore the cauldron of cultural forces that influence the Justices' inclination to protect minority tights, we get a distorted image of the countermajoritarian capacity of judicial review. ${ }^{400}$

In the end, Engel's heroic, countermajoritarian narrative is largely fiction. This is problematic not only because the dominant conception of Engel is inaccurate, but also because it has eclipsed other conversations in constitutional law in which Engel has purchase. Engel has a much richer, multidimensional story to tell than what we see in the countermajoritarian narrative-a story about social movements generating constitutional change, about the dialogic function of judicial review, and about popular constitutionalism. To those conversations the discussion turns next.

\section{B. The Influence of Culture in Generating Consitutional Change}

Over the past decade, one of the most significant contributions to the constitutional law literature has been legal history work showing the powerful influence of culture in general, and social movements in particular, in generating constitutional change. Thus far, this burgeoning body of scholarship has featured the civil rights movement, the women's movement, the labor movement, and the gay rights movement, showing each to have had a tremendous impact on the development of constitutional law. ${ }^{401}$ Not yet recognized is that the 1950s ecumenical movement is also an example of this phenomenon, and Engel another thread in a tapestry of constitutional meaning forged by larger societal change. ${ }^{402}$

400. This distorted image might well be viewed as a Platonic "noble lie," a psychological imperative that feeds not only the public's need for protection from dentrocracy's worst excesses, but also the Supreme Court's need for legitimacy in a land of majority rule. See supra notes 377,379 and accompanying text (discussing the Supreme Court's countermajoritarian capacity as the basis for most every normative theory of judicial review and the psychological imperative of a countermajoritarian Court).

401. See, e.g., Jack M. Balkin \& Reva B. Siegel, Principles, Practices, and Social Movements, 154 U. PA. L. REV. 927 (2006); Tomiko Brown-Nagin, Elites, Social Movements, and the Law: The Case of Affirmative Action, 105 CaLuM. L. REv. 1436 (2005); William N. Eskridge, Jr., Some Effects of Identity-Based Sacial Movements on Constitutional Law in the Twentieth Century, 100 Mich. L. REv. 2062 (2002); Michael J. Klarman, Windsor and Brown: Marriage Equality and Racial Equality, 127 HARV. L. REV. 127 (2013); James Gray Pope, The Thirieenth Amendment Versus the Commerce Clause: Labor and the Shaping of American Constitutional Law, 1921-1957, 102 CoLuM. L. REV. 1 (2002); Reva B. Siegel, Constitutional Culture. Social Movement Conflict and Constitutional Change: The Case of the De Facto ERA, 94 CALIF. L. RFv. 1323 (2006).

402. Others have recognized the ecumenical movement's impact in the civil rights arena, just not in the place it is closest to home-our understanding of the First Amendment's religion clauses. For a history of the ecumenical movement's involvenent in the struggle for racial equality, see generally James F. FIndLAY, JR., Church PEOPle IN THF, STRUGgle: ThE: NATIONAL COUNCIL OF ChuRCheS AND THE BLACK FreEDOM MOVEMENT, 1950-1970 (1993). For a discussion of the 1950 s ecumenical movement, see notes 80-83 and accompanying text above. 
Although it has been almost entirely overlooked in the law review literature, ${ }^{403}$ the 1950 s ecumenical movement played a powerful role in Engel in three ways. First, and most obviously, it produced the ecumenical Regents' Prayer at issue in the case. Second, and more broadly, it created a compromise position for those who wanted to keep religious observances in school but also accommodate religious diversity, a middle ground between traditional (i.e., Protestant) observances and none. Third, and most importantly, it showed the futility of that move, further fueling the impetus for change realized in Engel.

A brief review of the conundrum of school prayer illustrates the point. One option for states responding to the pressures of religious pluralism in the context of school religious observances was to simply stop those observances altogether. As previously discussed, this response was a prominent feature of the sociopolitical landscape when Engel was decided, particularly in the West and Midwest. ${ }^{404}$

A second option, and one that was also prominent at the time Engel was decided, was for schools to do nothing - to ignore the pressures of pluralism altogether. This was the dominant response in the East and South, where deep colonial customs and Bible Belt practices rendered religious observances in schools particularly well entrenched and resistant to change ${ }^{405}$ Still, one gets the sense that even here, the status quo could hold out for only so long. By the mid-twentieth century, Catholics and Jews were no longer outsiders; they were insiders, and increasingly demanded to be treated as such. ${ }^{406}$ As the pressures of pluralism mounted, states that wanted to keep religious observances in school would have to find another way. It was quickly becoming no longer enough to excuse religious minorities; states would need to find a way to include them. ${ }^{407}$

That brings us to the third option-the compromise position illustrated by the ecumenical prayer in Engel. For states that wanted to retain religious observances in school but make the content more amenable to religious minorities, the ecumenical approach seemed the ideal way to go. Except it wasn't. Experi-

403. My own search has revealed only one law review article about the ecumenical movement's impact on the Establishment Clause. See Robert C. Casad, The Establishment Clause and the Ectumenical Movement, 62 MiCH. L. Rev. 419 (1964).

404. See supra notes $86-88,92$ and accompanying text.

405. See supra notes $89-90$ and accompanying text.

406. See MORGAN, supra note 77, at 81-82 ("Roman Catholic consciousness of itself as a minority, set apart from the mainstream of American culture and community life, cvaporated. Laity and hierarchy alike, the Catholic community emerged from the Second World War newly confident, and eager to exert its influence on a culture which it now perceived as its own ...."); see also supra notes 76-79 and accompanying text (discussing the dominance of the "three great faiths" and "Judeo-Christian" tradition by the mid-1950s).

407. See People ex rel. Ring v. Bd. of Educ., 92 N.E. 251, 256 (IIl. 1910) ("The exclusion of a pupil from this part of the school exercises in which the rest of the school joins, separates him from his fellows, puts him in a class by himself, deprives him of his equality with the other pupils, subjects him to a religious stigma and places him at a disadvantage in the school ...."). 
ence showed that no one was happy, and the harder one tried to devise a prayer that pleased everyone, the closer one came to an empty formality that offended the religious and irreligious alike.

It was a lesson that was likely to replay elsewhere. States that were determined to keep religious observances in school but felt the need to bend to the realities of religious diversity were going to do what the school board in Engel did--move toward a more inclusive, ecumenical prayer. And that was going to prove unsatisfactory. And that was going to add even more pressure to just get rid of such practices altogether.

In an early draft of Engel, the Supreme Court recognized this conundrum explicitly. Even the most seemingly innocuous prayer would never please everyone, the Court wrote. ${ }^{408}$ The pressures of religious pluralism were propelling the nation toward constitutional change, and the ecumenical movement was fueling that momentum with the strong sense that there was no other way.

Thus far, I have discussed Engel's contribution to the literature on social movements as an engine of constitutional change, but Engel also has purchase for "court and culture" scholarship more generally. Recall that by the late $1880 \mathrm{~s}$, most states had enacted prohibitions against sectarian education in publicly funded schools. ${ }^{409}$ At the time, these provisions were viewed as having nothing to say about Bible reading and school prayer because the prevailing (i.e., Protestant) view was that such practices were not sectarian. It was not until the fall of Protestantism in the early to mid-twentieth century that the country began to take a different view, recognizing that the ban against sectarian practices included Protestant practices too. ${ }^{410}$

So stated, the Supreme Court in Engel can be viewed as just holding the nation to a standard it had long embraced on its own. Indeed, in that sense, Engel was a good seventy-five years late. The reason it did not feel that way is a lesson Engel teaches with stunning clarity: it was not the law that mattered, but our cultural conception of the law.

The point is important not only for "court and culture" scholars, but also for those writing in the area of law and religion. Although Sarah Gordon, Thomas Berg, Steven Green, and others have done important work on the extralegal narrative of the law in this area, ${ }^{41}$ there remains a striking paucity of discourse on the extralegal forces that drove the Justices' decisionmaking in

408. See supra text accompanying note 152 .

409. See supra notes 51-54 and accompanying text.

410. The first state to ban Bible reading from public schools-Ohio in 1869-did so well before the fall of Protestantism as the nation's de facto religious establishment, but it too proves the point. See GREEN, supra note 31, at 93-135 (discussing the "vibrant religious diversity" that led educators, and ultimately the Ohio Supreme Court, to view Bible reading as a sectarian practice).

41. See, e.g., GorDon, supra note 107; Gordon, stpra note 66; Berg, supra note 65; Berg, supra note 34; GREEN, supra note 31; Green, supra note 49. 
Engel, a marquee "law and religion" case. ${ }^{412}$ This paucity is all the more stunning in light of the lack of conventional sources that can plausibly explain the constitutional change that Engel wrought. ${ }^{413}$ To understand Engel, one must look beyond the Framers and original intent; the only way the decision makes sense is as a response to, and reflection of, larger societal forces of change.

\section{A Rare "Strong Form" of the Dialogic Function of Judicial Review}

The notion that judicial review functions as a dialogue with the coordinate branches and the American public is hardly new. Back in 1962, Alexander Bickel described the Supreme Court's use of judicial review as a "continuing colloquy" with the people and their representatives in which constitutional meaning is "evolved conversationally" rather than declared unilaterally ${ }^{414}$ Since then, a number of scholars have shown that, far from the juricentric world of constitutional law that first-year law students study, the Supreme Court is but a part of an ongoing conversation about constitutional meaning that continues over time until some sense of consensus is reached. ${ }^{415}$ Recent work on the role of nonjudicial actors in determining constitutional meaning (of which "court and culture" scholarship is a part) has only heightened scholarly interest in the dialogic function of judicial review.

Within this genre of scholarship, Engel has appeared as an example of how dialogic judicial review can go wrong-and rightly so. ${ }^{416}$ The majority's failure to set forth the limits of the Court's holding in the text as opposed to a foot-

412. I have found just four sources in the legal literature that undertake such an inquiry in more than passing fashion. See supra note 26 (listing sources). Why the underdeveloped discourse? It may be because Engel is now fifty years old and, over time, has come to stand for an ideal that scholarship has then built upon in analyzing later doctrinal developments. I credit with gratitude Paul Horwitz for this insight.

413. See Jeffries \& Ryan, supra note 26 , at 281 ("In terms of the conventional sources of 'legitimacy' in constitutional interprctation, the Supreme Court's Establishment Clause decisions are at least very venturesome, if not completely rootless."); Klarman, supra note 26, at 47 ("Neither doctrinal logic nor changes in Court composition can explain the dramatic departure effectuated by the Court in its post-1945 Establishment Clause decisions. Only an external account, focusing on deep political, social, and ideological forces, can plausibly explain this seachange in constitutional doctrine... Inexplicably, this sort of social and political history of the transformation of Establishment Clause doctrine remains largely unwritten.").

414. Alexander M. Bickel, The Least Dangerous Branch: The Supreme Court at THE BAR OF POLITICS 240, 244 (2d ed. 1986).

415. For particularly prominent examples, see LOUIS FISHER, CONSTITUTIONAL Dialogues: INTER Pretation as Political Process (1988); and Barry Friedman, Dialogue and Judicial Review, 91 MrCH. L. REV. 577 (1993).

416. See FISHER, supra note 415, at 181 ; see also Paul G. Kauper, The Warren Court: Religious Liberty and Church-State Relations, 67 MiCH. L. REv. 269, 288 (1968) ("A large part of the public furor aroused by Justice Black's blunt opinion in Engel might well have been avoided if the Court had given thought to the public impact of the decision and dealt more discreetly with the issue- as Justice Clark did in the later Schempp opinion."). 
note, and its curt, conclusory opinion devoid of a single citation, has to be one of the more wanting exercises of dialogic judicial review in Supreme Court history. ${ }^{417}$ Meanwhile, the concurring and dissenting opinions in Engel show how minority voices on the Court can contribute to confusion over the holding of a case. To the extent Engel was the opening salvo in a dialogue with the American people, little wonder the public's reaction was akin to a certain hand gesture in response.

That said, the Justices' opinions in Engel are in my mind the least interesting aspect of the decision for dialogic theory; the hidden gem of Engel lies in everything that happened after the decision was announced. That begins with Justice Black answering letter after letter of hate mail on the case. Justice Black told people to read the Engel opinion, and he often told them to write back if after reading it, they still disagreed with what the Supreme Court had done ${ }^{418}$ In so doing, he took the notion of a dialogue with the American people to a whole new level-a literal one.

Justice Clark did essentially the same thing, and he did it in two ways. First, he broke from longstanding tradition against commenting on the merits of a case to clarify Engel while speaking at a national convention. Second, he wrote the majority opinion in Schempp. Every aspect of the Schempp opinionfrom its styling, to its recitation of the facts, to its rich assurances of the exalted status of religion, to its explanation of why religious diversity rendered daily devotionals in school untenable - was written with the public in mind. Throw in Justice Brennan's insistence upon writing separately so he could talk to a Catholic audience, and it is hard to imagine a stronger example of the dialogic function of judicial review.

So viewed, dialogic theory simply looked away too soon. The Supreme Court decided Engel. The people reacted. And the Justices reacted to that reaction in letters, speeches, and their opinions in Schempp. This is not to say they did so in the way dialogic scholars have theorized. Although dialogic theory

417. One might wonder why, if the Justices took Engel to ease the nation into Schempp, they were not more attentive to the Engel opinion. While speculative, my sense is that the answer lies in the fact that the Justices saw Engel as a ruling so obvious they could not imagine the country taking a different view, See Sch. Dist. of Abington Twp. v. Schempp, 374 U.S. 203, 220-21 (1963) (describing Engel as resting on principles "so universally recognized" that the Court ruled "without the citation of a single case").

418. A number of these letters were quite direct. See, e.g., Letter from Justice Hugo L. Black to Lois Wilson (July 2, 1962) (Hugo LaFayette Black Papers, Box 358) ("In order' that you may know what the Court actually decided, I am sending you a copy of the opinion to which you referred. You will note that the Court decided that no State could prescribe official prayers through its politicians or officials. After you have read the opinion of the Court, I think you will find that there is not one word in it that puts a single obstacle in the way of any person in the United States who genuinely wants to pray his own prayer in his own way to the God he worships."). On the letter was written the annotation, "Lois Wilson was a famous movie actress (HLB)," id. (under]ining omitted), which she was, perhaps explaining why this letter was more detailed than most. See Lois Wilson, Silent ErA, http://www silentera.com/people/actresses/Wilson-Lois.html (last visited Feb. 23, 2015). For other examples of Justice Black's correspondence, see note 159 and accompanying text above. 
generally posits that the Court will moderate its position in response to sustained democratic dissent, ${ }^{419}$ Engel's aftermath shows there are other possibilities as well. Sometimes the Court will respond in dialogic fashion not by moderating its position, but by clarifying, limiting, or simply selling it better ininstead.

Whatever the response, scholars thus far have theorized what one might call a weak form of dialogic judicial review: dialogue is something that happens by virtue of the actions and reactions of various actors, whether they are thinking about it as dialogue or not. ${ }^{420}$ What Engel and Schempp show is that the dialogic function of judicial review can exist in strong form too. Sometimes the Supreme Court is actually trying to talk to the American people. That is, sometimes the Court is dialogic not only in what it does, but also in what it means to do.

This conception of the Supreme Court is dramatically different from that for which Engel and Schempp are famous. Engel's countermajoritarian narrative is the story of a Court fiercely independent from the sway of public opinion, with Schempp a story of the Justices doubling down on that stance. Yet the reality of both cases flips those narratives on their heads. The Justices' actions in the wake of Engel, and their subsequent opinions in Schempp, reveal a Court that cared deeply about the public's perception of its rulings. Nowhere is that more apparent than in the exercise of explicitly dialogic judicial review.

\section{Not All Popular Constitutionalism Is Created Equal}

Having discussed the dialogic function of judicial review, I turn now to one aspect of that dialogue-the voice of the people and their representatives. Over the past decade, the notion that the people and their representatives should play an active role in determining constitutional meaning has catapulted to the center stage of constitutional theory under an umbrella of work dubbed "popular constitutionalism." ${ }^{21}$ This genre of scholarship is notoriously elusive as to what the term means, ${ }^{422}$ but the central animating theory is that ours is a gov-

419. See FRIEDMAN, supra note 5, at 382 (discussing the moderating influence of dialogic judicial review).

420. See Friedman, supra note 415 , at $653-58$.

421. For a sampling of this work, see Larry D. Kramer, THe Pforle Themselves: popular Constitutionalism and Judictal Review (2004); Mark Tushnet, Taking the Constitution AWAy from the Courts (1999); Doni Gewirtzman, Glory Dcys: Popular Constitutionalism, Nostalgia, and the True Nature of Constitusional Culture, 93 GEO. L.J. 897 (2005); and Robert Post \& Reva Sicgel, Popular Constitutionalism, Departmentalism. and Judicial Supremacy, 92 CALIF. L. REv. 1027 (2004).

422. See Gewirtzman, supra note 421 , at 900 ("The problem begins with 'the People,' a term popular constitutionalists invoke with some regularity but are reluctant to define. To the extent there is a shared definition, it apparently refers to any participant in constitutional interpretation who is not a federal judge." (footnote omitted)); Larry Alexander \& Lawrence B. Solum, Popular? Constitutionalism?, 118 HARv. L. Rev. 1594, 1618 (2005) (reviewing KRAMER, supra note 421) ("But as articulated by Kramer, 'popular constitutionalism' lacks 
emment "of the people, by the people, for the people," ple and their representatives should be the ultimate arbiters of constitutional law. 424

By and large, Engel has not played a role in this discourse, although Lucas Powe has discussed it as an overlooked example of modern popular constitutionalism. ${ }^{425}$ By Powe's account, attempts to override Engel by constitutional amendment may have failed, but in the end the people won. Even today, school prayer remains a feature of some Southern schools. ${ }^{426}$

In my mind, Powe was right in citing Engel as a vastly underappreciated example of popular constitutionalism, but Engel's contribution to the literature in this area is even greater than Powe recognizes in two ways. First, Engel shows the variety of forms that popular constitutionalism might take, exposing qualitative differences in the way democratic dissent fosters constitutional discourse. Second, Engel shows that even popular constitutionalists have reason to celebrate judicial review: popular constitutionalism may not exist without it.

As to the first point, one cannot help but think of one of the earliest works on popular constitutionalism-Mark Tushnet's Taking the Constitution Away from the Courts ${ }^{427}$ - when thinking about the congressional amendment hearings to overturn Engel. When the hearings began, supporters of an amendment

even the articulation and relatively sharp definition of a cumulus cloud in the lower atmosphere."); L.A. Powe, Jr., Are "the People" Missing in Action (and Should Anyone Care)?, 83 TEX. L. REV. 855, 857 (2005) (reviewing KRAMER, supra note 421) ("Kramer's interpretation of what constitutes popular constintionalism may be so elusive that only he can apply it.").

423. President Abraham Lincoln, Gettysburg Address (Nov. 19, 1863), in ABRAHAM

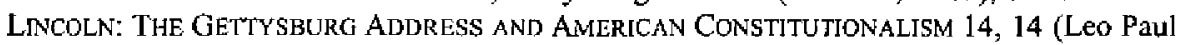
S. de Alvarez ed., 1976).

424. See KRAMER, supra note 421, at 107 ("In a world of popular constitutionalism, government officials are the regulated, not the regulators, and final interpretive authority rests with the people themselves."); Gewirtzman, supra note 421, at 898-99 (naming various popular constitutionalists and noting that " $[\varepsilon]$ ach argues that the People and their elected representatives should--and often do--play a substantial role in the creation, interpretation, evolution, and enforcement of constitutional norms"); Powe, supra note 422, at 895 ("Popular constitutionalism's core idea [is] that all citizens have the right to interpret the Constitution for themselves ....".).

425. See Powe, supra note 422, at 866, 875-77.

426. See McGuire, supra note 223, at 60,62 ("The ban on organized prayer-the Court's longest standing policy on devotional activities in public schools-is fully enforced, at least outside the South. Almost one quarter of southern students, though, report that these prayers remain a regular part of their education, despite the Court's long-established policy to the contrary. . . Because latiude decreases in a southerly direction, the negative coefficient confirms that the further south a school is located, the more recalcitrant it will be when it comes to adhering to the Court's mandates on school prayer."); Powe, supra note 422 , at $876-77$.

427. TUSHNET, supra note 421. 
had a majority in the Judiciary Committee and a majority in the House. ${ }^{428}$ The Constitution was theirs for the taking.

Then something unexpected happened. In the process of taking the Constitution away from the Supreme Court, committee members were forced to engage with the school prayer issue in concrete terms, as it would play out on the ground. When they did, most all of those congressmen decided that the Court had done alright after all (or at least came to understand that there was no other way). ${ }^{429}$

In my mind, the sort of deliberative process that played out in Congress is qualitatively different from the acts of outright defiance and low-level noncompliance that Powe cites as examples of popular constitutionalism in the wake of Engel. Indeed, it strikes me as qualitatively different from most everything that the people and their representatives did to register their dissent, and Engel shows us the gamut. Public denunciations. Billboards and picketing. Letters and editorials. Resolutions and legislation. Vows of defiance and resolute noncompliance. Calls to amend the Constitution, impeach the Justices, strip their jurisdiction, buy them Bibles, and inscribe the words "In God We Trust" above their bench. Engel puts flesh on the bones of what popular constitutionalism might look like, offering an opportunity to think about whether we like what we see.

Thus far, those who champion popular constitutionalism have focused on the word "popular" in popular constitutionalism, assuming, it appears, that as long as the people are the ones doing the deciding, the ideals of civic republicanism have been realized. ${ }^{430}$ Engel shows that is simply not true. There is another, critical component to civic republicanism, and it is reflected in the notion of deliberative democracy - an authentically discursive process in which arguments are marshaled, information gleaned, and the merits of competing positions fully considered. ${ }^{431}$ That is the quality that the amendment hearings had, and it is the quality that backlash politics largely lack.

428. See supra notes $275-77$ and accompanying text. Some were already predicting the timing of when the amendment would be ready for ratification by the states. See supra notc 277.

429. See supra note 388 (quoting members of Congress involved in the 1964 amendment process and the 1982 amendment process, in which the same sott of learning process played out).

430. See supra note 422; see also Powe, supra note 422, at 890-91 ("Popular constitutionalism embraces our modern notions of civic republicanism and the romantic ideal of an engaged citizenry."). For a primer on civic republicanism, see IsEult HONOHAN, CIVIC REPUULICANISM (2002).

431. See Ezekiel I. Emanuel, Where Civic Republicanism and Deliberative Democracy Meet, HASTINGS CENTTRR REP., Nov.-Dec. 1996, at 12, 13. For insightful discussions of deliberative democracy and the elements that define it, see DeLIBERATIVE DEMOCRACY: ESSAYS ON REason anid Politics (James Bohman \& William Rehg eds., 1997); AMY GutManN \&

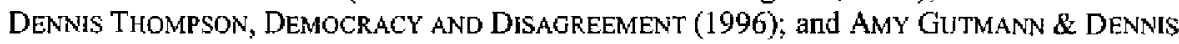
ThOMPSON, Why DELIBERATIVE DEMOCRACY? (2004). 
In Engel, the difference mattered, and it should matter to popular constitutionalists too. If the point of popular constitutionalism is for the people to decide the Constitution's meaning for themselves, then we ought to care how much thought goes into doing it. After all, this is the Constitution they are expounding. ${ }^{432}$ Popular constitutionalism that entails some modicum of deliberation is one thing; popular constitutionalism that amounts to little more than giving the middle finger is something altogether different. ${ }^{433}$ That's not even close to deliberative democracy. That's just defiance.

That brings me, briefly, to my second point-the importance of judicial review for popular constitutionalism, with Engel as a prime example. Despite the fragility of the status quo before Engel, the propriety of religious observances in public schools did not capture the nation's attention until 1962, when the Supreme Court struck down school prayer. It was Engel that launched a national conversation about the rights of religious minorities, Engel that triggered the democratic dissent that lies at the heart of popular constitutionalism, and Engel that led to the deliberative democracy at work in the amendment hearings.

In galvanizing debate, Engel democratized the Constitution, jump-starting civic engagement about the content of constitutional rights. Contemporary commentators recognized it. ${ }^{434}$ Justice Black wrote about it. ${ }^{435}$ And populist calls to arms illustrated it, albeit often in less than respectful fashion. ${ }^{436}$ At the risk of stating the obvious, none of the acts of democratic dissent in Engel's wake would have happened without Engel. As scholars rally to take the Constitution from the Court, Engel is a vivid reminder that popular constitutionalism without Supreme Court decisions may mean no popular constitutionalism at all.

432. See McCulloch v. Maryland, 17 U.S. (4 Wheat.) 316, 407 (1819) ("[W]e must never forget, that it is a constitution we are expounding.").

433. This is not to deny that even unreasoned outrage can serve a uscful purpose, only to say that it is a poor basis for constitutionalism. For an example of how even bigoted mob violence can play a productive part in the dialogic function of judicial review, consider the violence that followed Minersville School District v. Gobitis, 310 U.S. 586 (1940), which denied protection to Jehovah's Witnesses, and the Supreme Court's response in West Virginia State Board of Education v. Barnette, 319 U.S. 624 (1943), which overruled Gobitis. For an excellent account of the violent public reaction to Gobitis and the seeds it sowed for Barnette, see generally Shawn Francis Peters, Judging JeHovah's WiTnEsSES: Religious PERSecution and the Dawn of the Rights Revolution (2000).

434. See Kaufman, supra note 234 , at 51 (applauding "the widespread public dialogue touched off by the Court's opinions" in Engel and Schempp).

435. See Letter from Justice Hugo L. Black to Fred Larkins (July 6, 1962) (Hugo LaFayette Black Papers, Box 354) ("Although one never knows, I have an idea that the loyalty of the people for the principles of the First Amendment may emerge from this widespread discussion with more strength in the hearts of the people than they had before.").

436. "Wake up, America!" Representative Philip Philbin of Massachusetts declared. "Do not sit by while Communists, atheists, agnostics, materialists, bleeding hearts, and their unwitting dupes tamper with and imperil the very foundation stones, sacred beliefs, and shrines of our great majestic Nation." 109 CoNG. ReC. 19,278 (1963) (statement of Rep. Philbin). 
Here, then, lies one of the many ironies of Engel. The case famous for working against democratic values in fact played a key role in fomenting them. And those who set out to take the Constitution away from the Supreme Court instead gave it back at the end of the day. It is hard to imagine a higher form of popular constitutionalism than that.

\section{CONCLUSION}

A robust, historically accurate understanding of Engel v. Vitale is important not only because it shows the decision's strong countermajoritarian narrative to be inaccurate, but also because it shows us all that we have missed. As today's cutting-edge constitutional law scholarship continues to explore the varied ways in which constitutional meaning is generated by forces outside the Supreme Court, Engel stands as a vivid reminder that the lessons of legal history are for yesterday, today, and tomorrow. Understanding the Court in the past helps us know it in the present, and our conception of the Court in the present--how it responds to cultural forces, how it communicates with the American public, how it democratizes issues and jump-starts civic engagementgives us some sense of its dynamic, decidedly democratic potential going forward. For the past fifty years, we have not understood Engel well enough to see all that it has to offer. Now we do. 
